OAK RIDGE

NATIONAL LABORATORY

MANAGED BY UT-BATTELLE

FOR THE DEPARTMENT OF ENERGY

\title{
Costs of Producing Biomass from Riparian Buffer Strips
}

\author{
Anthony Turhollow
}

\author{
Energy Division
}

July 2000

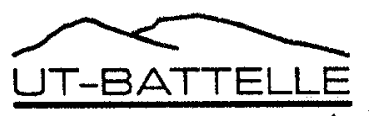




\title{
Costs of Producing Biomass from Riparian Buffer Strips
}

\author{
Anthony Turhollow \\ Energy Division \\ Oak Ridge National Laboratory, Oak Ridge, TN 37831 \\ Date Published: July 2000 \\ Prepared for the \\ U.S. DEPARTMENT OF ENERGY \\ Prepared by the \\ OAK RIDGE NATIONAL LABORATORY \\ Oak Ridge, Tennessee 37831-6285 \\ managed by \\ UNIVERSITY OF TENNESSEE-BATTELLE, LLC \\ for the \\ U.S. DEPARTMENT OF ENERGY \\ under contract DE-AC05-00OR22725
}





\section{CONTENTS}

Page

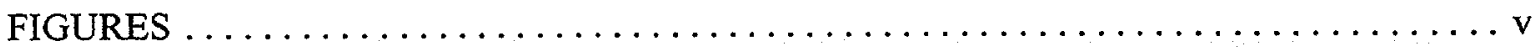

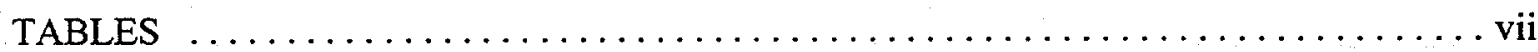

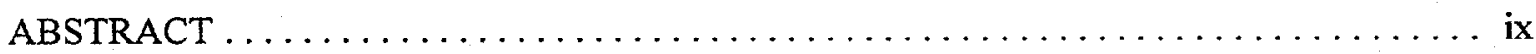

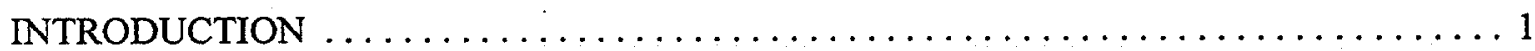

BACKGROUND AND ASSUMPTIONS $\ldots \ldots \ldots \ldots \ldots \ldots \ldots \ldots \ldots \ldots \ldots \ldots \ldots$

RIPARIAN BUFFER AND FILTER STRIPS $\ldots \ldots \ldots \ldots \ldots \ldots \ldots \ldots \ldots \ldots$

PARTICIPATION IN CONSERVATION PROGRAMS $\ldots \ldots \ldots \ldots \ldots \ldots \ldots \ldots 6$

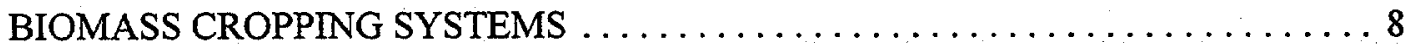

COSTING METHODOLOGY $\ldots \ldots \ldots \ldots \ldots \ldots \ldots \ldots \ldots \ldots \ldots \ldots$

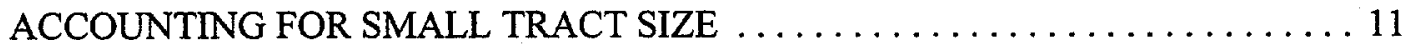

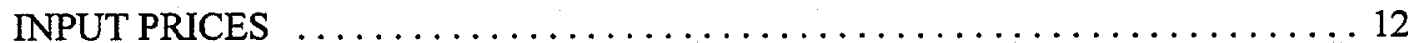

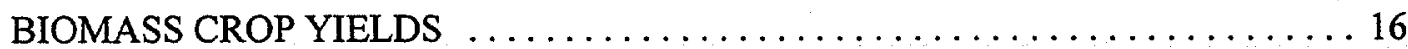

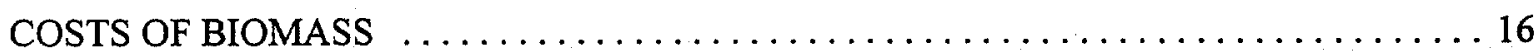

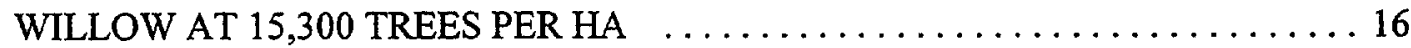

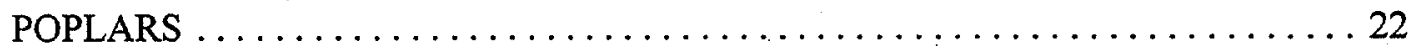

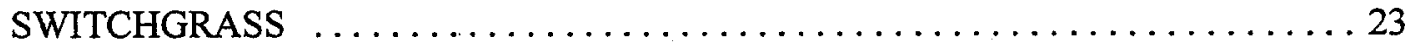

COSTS FOR BIOMASS WHEN BUFFER STRIPS ARE REQUIRED $\ldots \ldots \ldots \ldots 27$

ESTIMATES OF BIOMASS PRODUCED FROM BUFFER STRIPS $\ldots \ldots \ldots \ldots \ldots \ldots 28$

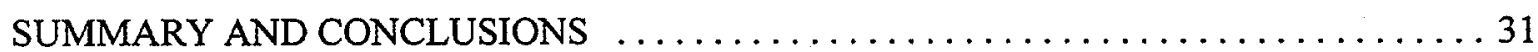

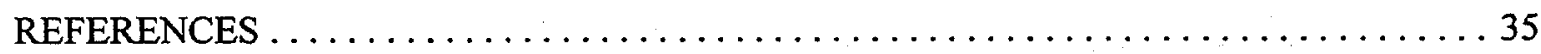

APPENDIX A: TABLES 1,7 , AND 13 IN ENGLISH UNITS $\ldots \ldots \ldots \ldots \ldots \ldots \ldots$

APPENDIX B: GENERAL, STATE AND NONGOVERNMENTAL PROGRAMS TO ENCOURAGE RIPARIAN BUFFER STRIPS $\ldots \ldots \ldots \ldots \ldots \ldots \ldots \ldots \ldots$

APPENDIX $\mathrm{C}$ : WOOD CHIP TRANSPORTATION COSTS $\ldots \ldots \ldots \ldots \ldots \ldots \ldots \ldots$

APPENDIX D: DERIVATION OF PRICE FROM NET PRESENT VALUE $\ldots \ldots \ldots \ldots .57$ 



\section{FIGURES}

Figure $\quad$ Page

1 The three zones of a riparian forest buffer $\ldots \ldots \ldots \ldots \ldots \ldots \ldots \ldots \ldots \ldots$

2 Delivered costs of willow chips with no payments, CRP payments,

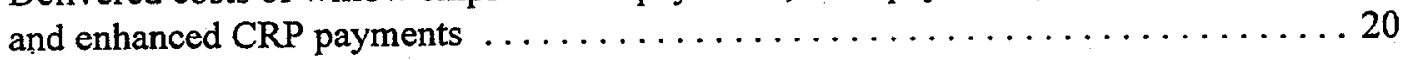

3 Percent of farm gate willow costs by activity for 10 and 22 year stand lives . . . . 21

4 Impact of yields on delivered willow cost based on 19 year stand life. . . . . . . 21

5 Costs of poplar chips with no payments, CRP payments, and enhanced CRP payments . . . . . . . . . . . . . . . . . . . . . . 24

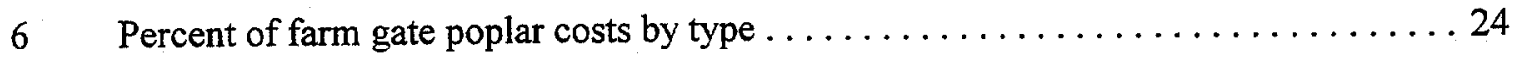

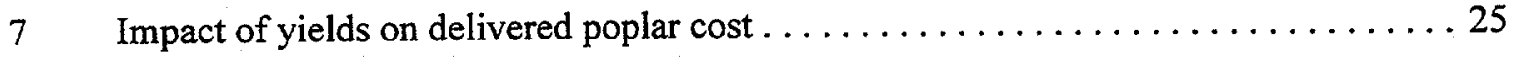

8 Costs of switchgrass bales with no payments, CRP payments, and

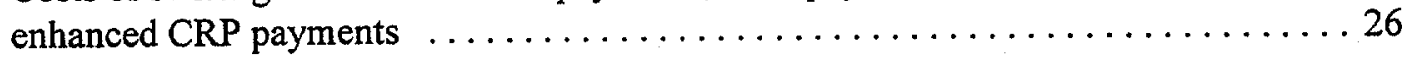

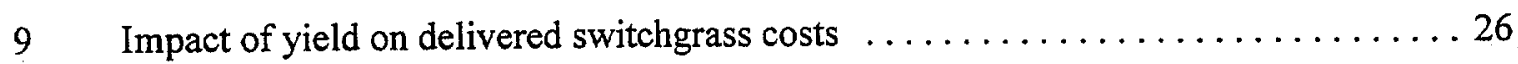

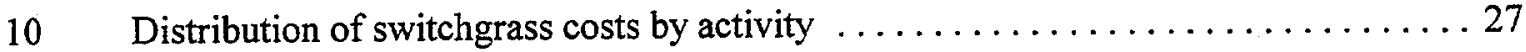

11 Costs for delivered biomass when buffer strips are required $\ldots \ldots \ldots \ldots \ldots \ldots 28$

12 Costs of willow, poplar, and switchgrass at 11.2 dry $\mathrm{Mg}$ /ha-year $\ldots \ldots \ldots \ldots 31$ 



\section{TABLES}

Table

Page

1 Broilers and cropland in the Delmarva Peninsula $\ldots \ldots \ldots \ldots \ldots \ldots \ldots \ldots$

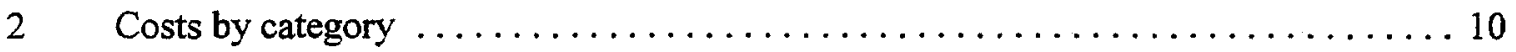

3 Gross Domestic Product chain-type price deflator, 1990-1999 . . . . . . . . . . 11

4 Cropland rental rates in Delaware and Maryland, $1994-1998 \ldots \ldots \ldots \ldots \ldots \ldots \ldots 12$

$5 \quad$ Cropland rental rates for Maryland by region, $1988-1992 \ldots \ldots \ldots \ldots \ldots \ldots \ldots$

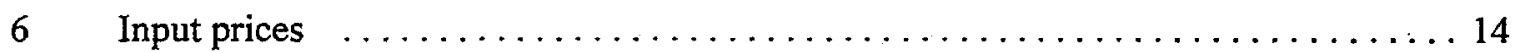

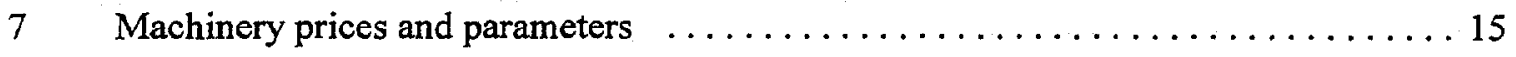

$8 \quad$ Machinery prices and parameters for poplar harvest equipment $\ldots \ldots \ldots \ldots \ldots 16$

9 Establishment practices for willow $\ldots \ldots \ldots \ldots \ldots \ldots \ldots \ldots \ldots \ldots \ldots \ldots$

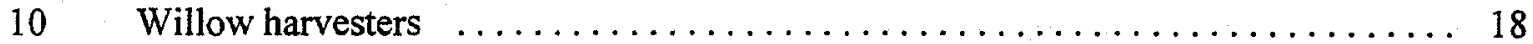

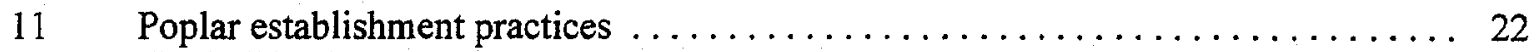

12 Establishment activities for switchgrass on cropland $\ldots \ldots \ldots \ldots \ldots \ldots \ldots$

13 Length of streams and buffer width by watershed in the

Delmarva Peninsula in the Chesapeake Bay drainage $\ldots \ldots \ldots \ldots \ldots \ldots \ldots . \ldots \ldots$

14 Area with stream length and buffer width data and buffer area needed $\ldots \ldots \ldots \ldots 31$ 



\begin{abstract}
Nutrient runoff from poultry litter applied to agricultural fields in the Delmarva Peninsula contributes to high nutrient loadings in Chesapeake Bay. One potential means of ameliorating this problem is the use of riparian buffer strips. Riparian buffer strips intercept overland flows of water, sediments, nutrients, and pollutants; and ground water flows of nutrients and pollutants.

Costs are estimated for three biomass systems grown on buffer strips: willow planted at a density of 15,300 trees/ha (6200 trees/acre); poplar planted at a density of 1345 trees/ha ( 545 trees/acre); and switchgrass. These costs are estimated for five different scenarios: (1) total economic costs, where everything is costed [cash costs, noncash costs (e.g., depreciation), land rent, labor]; (2) costs with Conservation Reserve Program (CRP) payments (which pays $50 \%$ of establishment costs and an annual land rent); (3) costs with enhanced CRP payments (which pays $95 \%$ of establishment costs and an annual payment of approximately $170 \%$ of land rent for trees and $150 \%$ of land rent for grasses); (4) costs when buffer strips are required, but harvest of biomass is not required [costs borne by biomass are for yield enhancing activities (e.g., fertilization), harvest, and transport]; and (5) costs when buffer strips are required. and harvest of biomass is required to remove nutrients (costs borne by biomass are for yield enhancing activities and transport). CRP regulations would have to change to allow harvest. Delivered costs of willow, poplar, and switchgrass [including transportation costs of $\$ 0.38 / \mathrm{GJ}$ $(\$ 0.40 /$ million Btu) for switchgrass and $\$ 0.57 / \mathrm{GJ}(\$ 0.60 /$ million Btu) for willow and poplar] at $11.2 \mathrm{dry} \mathrm{Mg} /$ ha-year (5 dry tons/acre-year) for the five cost scenarios listed above are $[\$ / \mathrm{GJ}$ (\$million Btu)]:

1) $3.30-5.45(3.45-5.75)$

2) $2.30-3.80(2.45-4.00)$

3) $1.70-2.45(1.80-2.60)$

4) $1.85-3.80(1.95-4.05)$

5) $0.80-1.50(0.85-1.60)$.

At yields of 15.7 to $17.9 \mathrm{GJ} /$ ha-year ( 7 to $8 \mathrm{dry}$ tons/acre-year), lower willow and poplar establishment costs, transportation costs of $\$ 0.30$ to $\$ 0.45 / \mathrm{GJ}$ ( $\$ 0.30-\$ 0.50 / \mathrm{million}$ Btu), and lower willow and poplar harvest costs, total economic costs for willow (19-year stand life), poplar, and switchgrass are $\$ 2.35$ to $\$ 2.60 / \mathrm{GJ}$ ( $\$ 2.50$ to $\$ 2.75 /$ million Btu). The potential production of biomass from riparian buffer strips in the Delmarva Peninsula ranges from 190,000 to $380,000 \mathrm{Mg}(210,000$ to 420,000 dry tons $)$ per year.
\end{abstract}




\section{INTRODUCTION}

In the Delmarva Peninsula ${ }^{1}$ large quantities of poultry (primarily chicken as broilers) are produced and litter from this poultry production is spread over agricultural fields. Because poultry litter is often applied to fields at a rate to meet crop nitrogen needs, phosphorus is applied in excess of crop nutrient needs. Runoff from application of poultry litter and other activities; such as fertilization, pesticide applications, urban wastes, and urban runoff; contribute to high levels of nutrient loading in Chesapeake Bay. One proposed means of reducing nutrient runoff from fields where poultry litter is applied, is to establish biomass crops as riparian buffer strips to intercept both overland and ground water flows. However, over time, nutrients may build up in buffer strips to the point where the capacity to absorb nutrients is saturated, at which point in time the buffer strips lose their effectiveness. This is especially true of phosphorus. Nitrogen may be an exception, because under appropriate conditions, denitrification can occur and nitrogen is given off to the atmosphere as a gas.) One means of removing some nutrients from the buffer strips would be to periodically harvest biomass from the strips.

Agriculture in the Delmarva Peninsula is primarily chickens for broiler production and raising of cash grain crops and vegetables. There are 0.52 million ha (1.3 million acres) of harvested cropland. About $8 \%$ of cropland is irrigated. Double cropping is practiced on 97,200 ha (240,000 acres). Of harvested acreage, about $85 \%$ is in soybeans, corn, and wheat. Forage crop production is relatively small (about $4 \%$ of cropland), 14,000 ha (35,000 acres) of hay and 8,500 ha (21,000 acres) of silage. Pasture is an additional 28,000 ha $(69,000$ acres) (Table 1) (USDOC/BEA 1993-1994). (Table 1 in its equivalent English units is Table A.1 in Appendix A.)

In the counties of Sussex in Delaware; Caroline, Dorchester, Somerset, Talbot, Wicomico, and Worcester in Maryland; and Accomack in Virginia; an estimated $600,000 \mathrm{Mg}$ (660,000 tons) of poultry litter, containing $2.7 \%$ nitrogen and $3.8 \%$ phosphorous (as $\mathrm{P}_{2} \mathrm{O}_{5}$ ), are produced annually (Antares Group Inc. et al 1999). These counties account for $92 \%$ of total broiler production in the Delmarva Peninsula. Over the entire Delmarva Peninsula and accounting for the additional broiler production in counties other than those listed above, if poultry litter is spread over all cropland, then annual nitrogen and phosphorous applications $\left(\right.$ as $\left.\mathrm{P}_{2} \mathrm{O}_{5}\right)$ would average $31 \mathrm{~kg} / \mathrm{ha}(28 \mathrm{lb} / \mathrm{acre})$ and $45 \mathrm{~kg} / \mathrm{ha}(40 \mathrm{lb} /$ acre), respectively.

There are a number of federal and state programs which help pay for establishing and maintaining riparian buffer strips (see Appendix B). One means of addressing issues relating to sedimentation and water quality has been the Conservation Reserve Program (CRP). It was initiated by Congress in 1985 and initially was directed toward reducing soil erosion on highly erodible cropland. The 1990 Farm Act changed the goals of the CRP toward addressing water quality and other environmental concerns. Under the CRP, participants (land owners or farm operators) voluntarily remove land from crop production for 10 to 15 years and establish a permanent cover (usually grasses or trees) in exchange for an annual rental payment and half the cost of establishing the permanent cover (USDA/ERS 1997). Land in the CRP is not allowed to be harvested except under emergency circumstances. If harvest of grasses and trees during the tenure of a CRP contract is desired, then the provisions of the CRP would have to be changed. However, in southern Iowa, switchgrass is presently being harvested from CRP land to be used

\footnotetext{
'The Delmarva Peninsula is east of Chesapeake Bay and west of the Atlantic Ocean and consists of Delaware, Maryland east of Chesapeake Bay, and a small portion of Virginia. Table 1 lists the counties in the Delmarva Peninsula.
} 
Table 1. Broilers and cropland in the Delmarva Peninsula

\begin{tabular}{|c|c|c|c|c|c|c|c|c|c|c|c|c|c|c|}
\hline \multirow{4}{*}{ Broilers sold (1000) } & \multicolumn{3}{|c|}{ Delaware } & & \multirow[b]{2}{*}{ Cecil } & \multicolumn{5}{|c|}{ Maryland } & \multicolumn{4}{|c|}{ Virginia } \\
\hline & Kent & Newcastle & Sussex & & & $\begin{array}{l}\text { Dor- } \\
\text { chester }\end{array}$ & Kent & $\begin{array}{l}\text { Queen } \\
\text { Anne's } \\
0500\end{array}$ & Somerset & Talbot & $\begin{array}{l}\text { Wico- } \\
\text { mico }\end{array}$ & $\begin{array}{c}\text { Worces- } \\
\text { ter }\end{array}$ & $\begin{array}{l}\text { Acco- } \\
\text { mack }\end{array}$ & Total \\
\hline & & & & & 0 & & 2157 & 8599 & 48523 & 8015 & 76498 & 57408 & 17406 & 497156 \\
\hline & \multicolumn{14}{|c|}{1000 ha } \\
\hline Land in farms & 79909 & 35277 & 123352 & 51409 & 32486 & 50106 & 53151 & 66943 & 22533 & 44173 & 36945 & 43530 & 37072 & 676887 \\
\hline Cropland & 67278 & 29731 & 103459 & 43162 & 24362 & 40589 & 45834 & 57618 & 16233 & 37913 & 28994 & 32766 & 29321 & 557261 \\
\hline Harvested & 63547 & 27470 & 99406 & 41260 & 20075 & 38328 & 42081 & 52647 & 15082 & 35759 & 27166 & 31253 & 28105 & 522181 \\
\hline Irrigated & 8212 & 823 & 15975 & 5996 & 288 & 4339 & 1931 & 3166 & 609 & 803 & 1861 & 942 & 3194 & 48139 \\
\hline Corn & 17486 & 12975 & 31984 & 9458 & 7532 & 7622 & 22174 & 22604 & 4581 & 12610 & 8011 & 15442 & 2799 & 175279 \\
\hline Wheat & 10870 & 3904 & 10227 & 9268 & 2534 . & 8082 & 4831 & 10907 & 2675 & 7500 & 3949 & 2107 & 8117 & 84973 \\
\hline Sorghum & 387 & & 3455 & 788 & & 1941 & & 245 & 110 & 432 & 988 & 40 & & 8386 \\
\hline Barley & 8105 & 600 & 6515 & 4655 & 1039 & 3896 & 902 & 1962 & 380 & 1002 & 382 & 299 & & 29736 \\
\hline Oats & 194 & & 103 & 20 & 37 & & 40 & 8 & & 21 & 4 & & 22 & 449 \\
\hline Rye & 63 & 28 & 209 & 43 & 12 & 15 & 96 & 43 & & 28 & 71 & & 51 & 657 \\
\hline Soybeans & 33057 & 10361 & 50458 & 24782 & 5845 & 25104 & 14414 & 23845 & 8714 & 19100 & 15503 & 15394 & 19774 & 266349 \\
\hline Canola & & & & 187 & & & 152 & 83 & & & & & & 422 \\
\hline Potatoes & 1671 & 429 & 1 & 2 & & & & & & & & 409 & & 2513 \\
\hline Sweet potatoes & & & & & & 2 & & & & & 15 & & 181 & 198 \\
\hline Cotton & & & & & & & & & & & & & 218 & 218 \\
\hline Hay & 1913 & 1329 & 1595 & 1283 & 3359 & 327 & 1331 & 1179 & 449 & 502 & 449 & 287 & 73 & 14076 \\
\hline Corn silage & 1666 & 389 & 1770 & 845 & 1111 & & 1107 & 720 & 155 & 272 & 87 & 102 & & 8223 \\
\hline Sorghum silage & 22 & & 294 & 28 & & & 7 & & & & & & & 350 \\
\hline Vegetables & 6779 & 433 & 9946 & 2544 & 76 & 2363 & 416 & 1006 & 441 & 395 & 1134 & 140 & & 25672 \\
\hline Orchards & & & & & & & & & & & & & 50 & 50 \\
\hline Nursery and greenhouse & 199 & 138 & 283 & 139 & & 30 & & 341 & 52 & 170 & 251 & 13 & 127 & 1743 \\
\hline All crops & 82412 & 30586 & 116839 & 54041 & 21545 & 49381 & 45470 & 62942 & 17558 & 42033 & 30843 & 34232 & 31412 & 619294 \\
\hline Double crop & 18864 & 3116 & 17433 & 12781 & 1470 & 11053 & 3390 & 10294 & 2476 & 6274 & 3677 & 2978 & 3306 & 97114 \\
\hline Pasture & 4257 & 1418 & 2747 & 1751 & 5428 & 1144 & 1770 & 2517 & 682 & 783 & 1318 & 2810 & 1135 & 27761 \\
\hline Woodland pasture & 1009 & 259 & 1016 & 417 & 387 & 500 & 222 & 624 & 213 & 210 & 662 & 969 & 164 & 6651 \\
\hline Woodland on farms & 9021 & 3039 & 14748 & 6503 & 4665 & 6970 & 5068 & 7496 & 4667 & 4768 & 5964 & 7761 & 6134 & 86803 \\
\hline
\end{tabular}

${ }^{a}$ Broiler data in Delaware for Kent and New Castle counties is not disaggregated, but most broilers are likely in Kent County.

Source: USDOC/BOC (1993-1994) 
in a test to cofire switchgrass and coal in an electric power generating station. Where one is trying to prevent nutrients from reaching water bodies, not permitting harvest may be counter productive. Because part of the purpose of the CRP is to enhance wildlife habitat and concerns during the nesting period, no harvest is allowed from April 15 to August 15.

In Maryland an enhanced CRP program, known as the Conservation Reserve Enhancement Program, was instituted in 1998. In this program, the federal CRP and Maryland state programs, in cooperation with the Chesapeake Bay Foundation and Ducks Unlimited, pay up to $95 \%$ of establishment costs for riparian vegetative buffers (or filter strips), make rental payments of $170 \%$ of prevailing rental rates for land planted to trees and $150 \%$ of prevailing rental rates for land planted to grasses, and pay a $\$ 12.35 /$ ha $(\$ 5 /$ acre $)$ annual payment for buffer strip maintenance. (If a planted area qualifies as a riparian forest buffer strip, then up to $100 \%$ of establishment costs are reimbursed. In this report, the buffer strips considered are assumed to qualify as riparian vegetative buffers for costing purposes.) Up to $\$ 1420 /$ ha $(\$ 575 /$ acre) and $\$ 988 /$ ha ( $\$ 400 /$ acre) of establishment costs are reimbursed for hardwood trees and warm season grasses, respectively. [For a vegetative buffer $95 \%$ of these maximum establishment costs can be reimbursed for trees, up to $\$ 1420 / \mathrm{ha}^{*} 0.95=\$ 1349 / \mathrm{ha}(\$ 575 /$ acre $* 0.95=\$ 546 /$ acre $)$. $]$ There is a goal of enrolling 40,400 ha (100,000 acres) in Maryland (Maryland Department of Agriculture, c. 1998).

One potential means of encouraging riparian buffer strips to be created along waterways would be to allow landowners to produces crops from these strips that, when harvested, would still allow the buffer strip to function to intercept nutrients, soil particles, and pesticides. Perennial biomass crops, such as perennial grasses and short rotation woody crops (SRWC), could possibly meet this requirement. The harvested biomass could be used for energy in a number of ways. At present, the most likely uses would be for cofiring with coal in an electric power generating facility, for heating buildings, or for cogenerating steam and electricity at small scales. In the future, biomass could be converted to gaseous or liquid fuels (e.g., ethanol). [See Antares Group Inc. et al (1999) for examples of potential biomass use in the Delmarva Peninsula.]

It is possible that regulations could be promulgated that require riparian buffer strips to be established if poultry litter is to be spread on agricultural fields or for other reasons, such as soil erosion control, streambank erosion control, or to improve water quality in general. This would change the economics of biomass production from riparian buffer strips because the cost of establishing and maintaining the crops in the buffer strips would be borne by activities that contribute to nutrient and pollutant runoff. Only the costs of enhancing yields (e.g., fertilization if advantageous and it does not degrade the functioning of the buffer strip), harvest, and transportation would be borne by biomass produced from buffer strips. If periodic harvest is required by regulation to remove nutrient buildup from the buffer strip, then only the costs of enhancing yields and transportation would be borne by the biomass.

In this report, costs are estimated for producing biomass from riparian buffer strips in the Delmarva Peninsula. There are five levels of costs estimated. First, total economic costs (referred to as total costs) are estimated. Second, costs after payments from the standard CRP program are estimated. Third, costs after payments from the enhanced CRP program are estimated. For the enhanced CRP program it is assumed that buffer strips created with biomass crops would be reimbursed for establishment costs at the rate for vegetative buffers, up to $\$ 1349 /$ ha $(\$ 546 /$ acre) for SRWC and up to $\$ 988 / \mathrm{ha}$ ( $\$ 400 /$ acre) for switchgrass. In the second and third cases it is assumed that biomass crops can be planted in a program that receives payments the same as land enrolled in the CRP or enhanced CRP, and that the biomass crops can be harvested and used for energy purposes. In the fourth and fifth cases, buffer strips are assumed to be required (e.g., by regulation) if poultry litter is to be applied to 
agricultural fields. The fourth case is where buffer strips are required, but harvest of the biomass to remove nutrients is not required. In the fifth case buffer strips are required and harvest is required to remove nutrients from the buffer strip. Therefore, in the fourth and fifth cases, a significant fraction of the costs is associated with the application of poultry litter to agricultural fields (i.e., establishing the buffer strip and in the fifth case also harvesting the biomass) and does not affect the decision whether to harvest and/or transport the biomass for use as a fuel. Costs for the fourth and fifth cases are reported in the section entitled "Costs for biomass when buffer strips are required." Costs are estimated for willow and poplar as wood chips and switchgrass as bales of hay. Costs are calculated using $19.8 \mathrm{GJ} / \mathrm{dry} \mathrm{Mg}(17 \mathrm{million}$ Btu/dry ton) for willows and poplars and $16.4 \mathrm{GJ} / \mathrm{dry} \mathrm{Mg}$ (15 million Btu/dry ton) for switchgrass.

The width of buffer strips depends upon the circumstances at a site. In this report, it is assumed that strips are $30 \mathrm{~m}\left(100^{\prime}\right)$ wide. For a $40.5 \mathrm{ha}(100$ acre) square field with a buffer strip on one side, the buffer strip is $2100^{\prime}$ long by $30 \mathrm{~m}\left(100^{\prime}\right)$ wide, or contain 1.9 ha ( 4.8

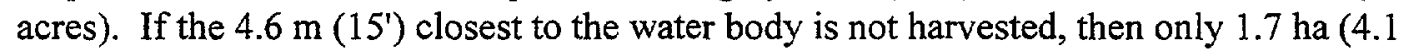
acres) are available for harvest. This is less than the minimum size tract one would ideally want to harvest with trees.

One of the concerns about costs is the small size of the potentially harvestable area in a buffer strip. The costs in the main body of the report are for large tracts. The effects of small tracts are relatively minor and are reported in the Summary and Conclusions.

\section{BACKGROUND AND ASSUMPTIONS}

\section{RIPARIAN BUFFER AND FILTER STRIPS}

A riparian buffer strip is an area of trees and/or shrubs and/or grasses adjacent to and upslope from water bodies. A filter strip is a strip or area of vegetation for removing sediment, organic matter, and other pollutants from runoff and wastewater. Its purpose is: "to remove sediment and other pollutants from runoff by filtration, infiltration, absorption, adsorption, decomposition, and volatilization, resulting in improved water quality and protecting the environment" (USDANRCS 1997a). Note that filter strips and buffer strips are defined differently. The Natural Resources Conservation Service (NRCS) and some states have promulgated standards for riparian forest buffer and filter strips. [For NRCS Standards see Conservation Practice Standard, Riparian Forest Buffer (Acre), Code 391A and Conservation Practice Standard, Filter Strip (acre) Code 393A (USDA/NRCS 1997a,b).] In some cases states have their own standards or they may use national NRCS standards. Delaware has a standard for filter strips but uses the NRCS standard for riparian forest buffers (personal communication, Paul M. Petrichenko, National Resources Conservation Service, Dover, DE; January 11, 1999). Maryland uses NRCS standards for riparian forest buffer and filter strips (personal communication, Mark Wagener, National Resources Conservation Service, Annapolis, MD, June 4, 1999). 
The purposes of riparian forest buffers are:

- Create shade to reduce water temperatures to improve habitat for aquatic organisms;

- Provide a source of detritus and large woody debris for aquatic organisms and provide habitat for wildlife;

- Reduce amounts of sediment, organic material, nutrients and pesticides in surface runoff and reduce nutrients, and other chemicals in shallow ground water flow (USDA/NRCS 1997a).

Under NRCS standards, riparian forest buffers consist of three zones (Fig. 1). Zone 1 begins at the normal water line or top of the bank and extends a minimum of $4.6 \mathrm{~m}$ (15') away from the water. Dominant vegetation consists of trees and shrubs. Occasional removal of some tree and shrub products is permitted as long as the intended purposes are not compromised by the loss of vegetation or disturbance.

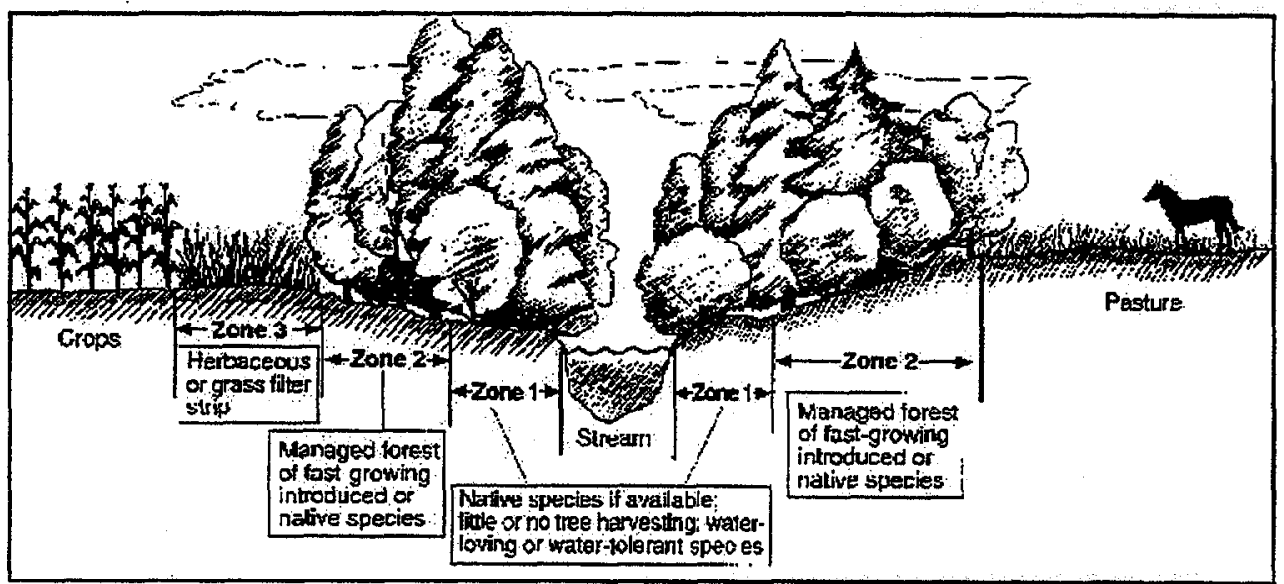

Fig. 1. The three zones of a riparian forest buffer (Source: USDA/NRCS).

Zone 2 begins at the edge of zone 1 and extends a minimum of $6.1 \mathrm{~m}\left(20^{\prime}\right)$ away from the water. The minimum combined widths of zones 1 and 2 are $30 \mathrm{~m} \mathrm{(100)} \mathrm{or} 30 \%$ of the flood

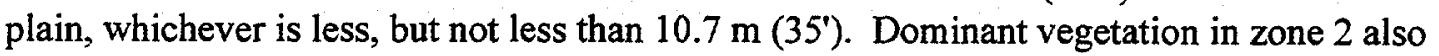
consists of trees and shrubs. Removal of trees and shrubs on a periodic and regular basis is permitted.

Zone 3 is up gradient of zone 2 and its purpose is to control concentrated flow erosion or mass soil movement (USDA/NRCS 1997b). Zone 3 is designed in accordance with criteria in filter strip standards (393A) (USDA/NRCS 1997a).

In Delaware, filter strips are designed with trees with a dense ground cover and/or a thick

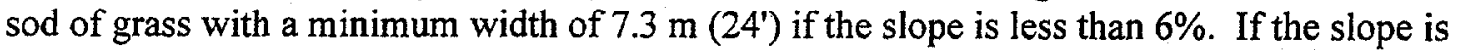
greater than $6 \%$, then the width of the filter strip in meters $(\mathrm{ft})$ is determined using the formula $1.22 \% \%$ slope ( $4 \% \%$ slope) (e.g., if the slope is $8 \%$ then the width of the filter strip is $\left.9.76 \mathrm{~m}\left(32^{\prime}\right)\left[1.22 * 8=9.76 \mathrm{~m}\left(4 * 8=32^{\prime}\right)\right]\right\}$. Grass species that are approved for planting are: tall fescue (Ky 31$)$ at $67.2 \mathrm{~kg} / \mathrm{ha}(60 \mathrm{lb} / \mathrm{acre})$, reed canarygrass at $22.4 \mathrm{~kg} / \mathrm{ha}(20 \mathrm{lb} / \mathrm{acre})$, and a mixture of reed canarygrass at $11.2 \mathrm{~kg} / \mathrm{ha}(10 \mathrm{lb} / \mathrm{acre})$ and tall fescue (Ky 31) at $33.6 \mathrm{~kg} / \mathrm{ha}$ (30 lb/acre). Fertilization is done according to soil tests. Harvest is permitted (USDA/SCS, Delaware 1984). 
In zones 2 and 3 of a riparian forest buffer and in filter strips, harvest of biomass is allowed. Assuming that in zones 2 and 3 of forest buffers and in filter strips; willow, poplar, and switchgrass can serve the required functions described previously and are allowed to be harvested on a periodic basis; then costs are estimated for producing biomass from these areas.

\section{PARTICIPATION IN CONSERVATION PROGRAMS}

Landowners'/farm operators' decisions to participate in conservation programs such as the CRP are affected by their knowledge of the program and program characteristics. Esseks and Kraft (1986, 1988, 1989); Force and Bills (1989); Hatley et al. (1989); and Mortensen et al. (1989) discuss factors that affect participation and nonparticipation in the CRP. One should note that some of the problems these authors discuss have been addressed by changes to the CRP process, as discussed below.

Esseks and Kraft (1986) found that after the first three CRP sign-ups in 1986, 41\% of nonbidders believed their land was ineligible for the CRP. However, in most cases this was a mistaken belief. This percent decreased over time as landowners became more familiar with the CRP. Economic considerations, such as perceived inadequate annual rental payments and the belief that more could be earned by cropping than enrolling in the CRP, discouraged some nonbidders. Another obstacle to some was the 10-year enrollment requirement. Five years would have been more acceptable to many.

In the original formulation of the CRP, landowners bid for an annual rental payment, and if the payment bid was above the regional ceiling (not differentiated by land quality), then the bid was rejected. A substantial fraction of the nonbidders did not accurately know the maximum rate. Rates were only published after each sign-up. Some bidders were discouraged if they assumed annual rental payments would be too low. Because there was a maximum regional rental rate, owners of highly productive cropland that may have been desirable to have enrolled in the CRP did not bid that land because the annual rental payment was perceived as being too low. Higher annual rental payment would have encouraged some additional bidding. However, Esseks and Kraft found that a $\$ 25 / \mathrm{ha}$ (\$10/acre) increase in annual rental payment would have only increased bids by 11 to $24 \%$ across four corn belt sites. Farmers with off-farm income and those who perceived their land as being erosive were more likely to participate in the CRP. Another possible incentive to encourage CRP participation is to allow grazing or haying of CRP land. However, this option is strongly opposed by cattle groups (Esseks and Kraft 1986). With changes in the CRP procedure, land rental rates requested by bidders are just one of seven factors considered in whether to accept a bid, and land productivity based rental rates are now published during the bidding process.

Getting CRP participants to plant trees has been difficult. The CRP had a goal of $12.5 \%$ of enrolled acres planted in trees. But of 36.4 million acres enrolled in sign-ups 1 to 12 (1986 to 1992$)$, only 1 million ha ( 2.5 million acres) or $6.8 \%$ was planted to trees. In the Southeast (Alabama, Florida, Georgia, and South Carolina) and Delta States (Arkansas, Louisiana, and Mississippi) $77 \%$ and $60 \%$ of enrolled acreages were planted to trees, respectively. The only other region with a high percentage of tree planting was the Northeast with $47 \%$, but total enrolled area was only 10,000 ha $(25,000$ acres) (USDA/ERS 1994). Even with more recent sign-ups this has not changed significantly. In sign-up 15 in $1997,6.6 \%$ of the enrolled area was planted to trees (Osborn 1997)

The southern states where significant tree planting on CRP land has taken place have existing markets for timber and some state and federal agency offices within these states have 
made concrete efforts to encourage and assist tree planting (Mixon and Thompson 1989, Morse 1987). In a study in southern Illinois, which is $30 \%$ covered by commercial forest land, those who planted trees on CRP land tended to be: 1) younger than nontree planting CRP participants, 2) have off-farm incomes, 3) have farms of less than 40 ha (100 acres), and 4) have owned land less than 10 years. The most frequently cited purposes for tree planting were conservation and wildlife habitat. Only $24 \%$ reported timber production as the motivation for tree planting. The three most important reasons for not planting trees under the CRP were length of timber rotation, lack of information on tree planting, and the annual rental payment was not high enough (Olmstead and McCurdy 1989). In a North Dakota study where only $5.3 \%$ of CRP land was planted to trees, $30 \%$ of CRP participants indicated a willingness to consider planting trees if the cost share percentage were higher (Mortensen et al. 1989).

West (1988) cites problems associated with tree plantings on CRP lands as: producers cannot effectively manage tree plantings that are small and fragmented and a reluctance to break off parts of fields to plant to trees. West notes that of lands from the Soil Bank Program of the 1950 s planted to trees, $90 \%$ are still in trees.

Starting in 1988 , filter strips 20 to $30 \mathrm{~m}\left(65^{\prime}\right.$ to $\left.100^{\prime}\right)$ wide became eligible for inclusion in the CRP and 1.6 to 2 million ha (4 to 5 million acres) of cropland were eligible for enrollment under this criterion. In 1994 only 21,000 ha (52,000 acres) of filter strips were included in the CRP (Lant et al. 1995). [The 1996 Farm Act expanded eligibility significantly for filter strips, to 8.5 million ha (21 million acres).] Esseks and Kraft (1989) found that about half of potential CRP participants were unaware of the filter strip option. Reasons cited for not enrolling in CRP filter strips were economic, such as: (1) a higher return could be earned farming the land, (2) the length of commitment reduces flexibility to respond to changing economic circumstances, and (3) the reduced acreage farmed interferes with efficient machinery utilization. Other reasons cited were simply a desire not to deal with government programs and an aversion to government control of farming operations.

Planting trees reduces cropping flexibility even more than planting grasses and at the midwestern sites surveyed there is concern for plugging of drain tiles by tree roots. (Drain tiles may decrease the effectiveness of filter strips to remove nitrogen from groundwater because they may allow water to bypass the filter strips.) Only $26 \%$ of respondents felt they could not market timber profitably. Lands eligible for filter strips tend to be more productive lands, so the maximum rental rates discouraged enrollment of this land in the CRP (Lant et al. 1995).

Lant et al. (1995) presented landowners and/or farm operators with land eligible for enrollment as CRP filter strips with the options for: (1) enrollment of filter strips in the CRP for 10 years with annual payments and (2) enrollment of filter strips with a 30-year easement with provisions as in the Wetland Reserve Program (e.g., no crop production) with a lump sum payment. Landowners/operators preferred the annual rental payments over the lump sum easement payment. Even when the lump sum was greater than the market price of the land, a majority of landowners/operators preferred to farm the potential filter strip instead of accepting the easement. [Easement payments as high as $\$ 1600 /$ ha $(\$ 4000 /$ acre) were offered.] Increases in annual rental rates above $\$ 395 / \mathrm{ha}(\$ 160 /$ acre) brought little additional participation. Nonfinancial reasons for not participating were important.

Purvis et al. (1989) mention a pilot program in the Black Creek watershed in northeastern Indiana in which farmers were offered a one-time lump sum payment to establish filter strips along streams. Farmers were allowed to hay these filter strips. Nine years after the filter strips were installed, $92 \%$ of participating farmers still maintained their filter strips. 
Over time the CRP has been modified, partly in response to some of the above observations. Since 1991, a national environmental benefits index (EBI) has been used to rank offers of land to enroll in the CRP. The EBI is the sum of six environmental factors: (1) wildlife habitat; (2) water quality benefits; (3) soil erosion; (4) long-term retention of trees, shrubs, and wetlands; (5) air quality; and (6) conservation priority area; and a seventh factor, cost. Weightings of these factors has changed over time. Offered rental rates are now screened against productivity based soil rental rates that are announced during the sign-up period (Feather et al. 1998, Osborn 1997, Smith 1999).

Under authority of the 1996 Farm Act, there is now a continuous sign-up for land to be devoted to specific purposes, including: filter strips, riparian buffers, grassed waterways, field windbreaks, shelterbelts, living snow fences, salt-tolerant vegetation, shallow water areas for wildlife, and wellhead protection. Land for these purposes is accepted for the CRP as long as the land owner is willing to accept a rental payment limited to a maximum productivityadjusted payment rate that is calculated by the Farm Services Agency of the U.S. Department of Agriculture. As of March 1999, 340,000 ha ( 841,000 acres) has been enrolled under the continuous sign-up.

While financial considerations and incentives are important to landowner/farm operator participation in programs such as the CRP, merely increasing the financial incentives will not increase participation to its fullest. Landowners/farm operators must be knowledgeable about program eligibility and options and the financial incentives. If maximum participation in conservation programs is desired, then federal and state agencies must make a concerted effort to inform potential participants of the programs and their characteristics and make participation in the programs as easy as is reasonable. It appears that once trees or filter strips are established, most are maintained by land owners and farm operators.

\section{BIOMASS CROPPING SYSTEMS}

Short-rotation woody crop (SRWC) systems can be designed to produce wood for energy and/or pulp and energy. In Europe, especially Sweden, willows (Salix spp.) are being planted at dense spacings of 15,300 trees/ha (6200 trees/acre), harvested after three years with a diameter breast height (DBH) of less than $7.62 \mathrm{~cm} \mathrm{(3"),} \mathrm{and} \mathrm{allowed} \mathrm{to} \mathrm{coppice.} \mathrm{The} \mathrm{biomass}$ is being used for energy. In the United States poplars (Populus spp.) are being planted at much wider spacings [e.g., $2.44 \mathrm{~m} \times 2.44 \mathrm{~m}\left(8^{\prime} \times 8^{\prime}\right), 2.44 \mathrm{~m} \mathrm{x} 3.05 \mathrm{~m}\left(8^{\prime} \times 10^{\prime}\right)$ ] so only 1680 or 1345 trees are planted per ha ( 680 or 545 trees are planted per acre), are harvested at 6 to 10 years of age depending upon climatic and soil conditions and crop management, and not allowed to regrow by coppice (Culshaw and Stokes 1995). This biomass is being used primarily for pulp (65-75\% of the harvested biomass) and the remainder (25-35\%), the bark and limbs, for energy.

In this report two SRWC systems are costed for use in riparian buffer strips. The first system is willow planted mechanically at a density of 15,300 trees/ha (6200 trees/acre), mowed at the end of the first growing season, harvested using modified agricultural equipment at the end of the fourth growing season and every three years thereafter. Because coppicing is desired, harvest takes place during the winter months. The trees are chipped as they are harvested, blown into a forage wagon, which in turn is dumped into a chip van which is taken to the place where the biomass is used. Willow stand life is varied from 9 to 22 years. The second system is poplars planted by hand at a density of 1345 trees/ha ( 545 trees/acre) that are assumed to be harvested after 10 years with conventional forestry equipment. Note that harvest at the end of 10 years would be consistent with a 10-year CRP

contract. Because no coppicing is desired, harvest can be any time during the year. However, 
because of concerns for wildlife, the harvest window would exclude the period April 15 to August 15.

A third system that is costed is switchgrass (Panicum virgatum). Harvest is with conventional haying equipment. A single annual late summer/fall harvest is assumed and, because of wildlife concerns, would take place after August 15.

Note that under the CRP most plantings are of mixed species, the species to be planted have to be approved, and harvest is not generally allowed. The two systems that are costed in this report with CRP and with enhanced CRP payments, are two scenarios in which it is assumed that biomass is allowed to be planted as.willow, poplar, or switchgrass and harvested for use as energy, and these plantings are eligible to receive payments that are equivalent to those received from the CRP and enhanced CRP programs.

\section{COSTING METHODOLOGY}

Costing of biomass systems requires many assumptions. The methodology and most of the assumptions used are from the BIOCOST Model (Walsh and Becker 1996). These are supplemented when necessary from Turhollow et al. (1998) and an unpublished report by Turhollow on SRWC transportation costs, which is included in Appendix C.

Costs are calculated using a spreadsheet model based on inputs used in the BIOCOST Model. The BIOCOST Model itself is not used. Costs are calculated using a total economic cost accounting approach, as is used in the BIOCOST Model (Walsh and Becker 1996). Under this approach cash and noncash, variable and fixed costs are included. This methodology is used by the U.S. Department of Agriculture for estimating costs of traditional agricultural crops such as corn, wheat, soybeans, and cotton. The total economic cost accounting approach takes a long run perspective, in that over a long period of time all costs must be covered by revenue from products sold (i.e., all costs in the long run are variable).

While costs are calculated using a total economic cost accounting approach, this is merely an accounting method, and some farmers may be willing to produce crops for less than the costs calculated from total economic cost accounting. In the short run farmers need only cover their variable costs, because they are better off financially producing something as long as their variable costs are covered and they are contributing something toward their fixed costs. While rent is charged for land, some farmers may own the land so the concept of rent to them is merely an opportunity cost and not an out-of-pocket expense. Under the total economic cost accounting approach, land is a large fraction of total costs, $18 \%$ to $26 \%$. If the land is owned outright by a farmer, the farmer may not require a rate of return equal to the $\$ 141 /$ ha ( $\$ 57 /$ acre) land rent charged for cropland. Land-owning farmers may not calculate the full rental value in calculating the price at which they are willing to sell.

There are two types of custom operators, those who perform custom operations as a fulltime occupation (e.g., harvesting SRWC) and those who are farmers who do custom operations (e.g., tillage) as a side occupation when they have time. The full time custom operator is likely to charge rates in line with a total economic cost accounting approach. The part-time custom operator may only charge slightly higher than his variable costs plus a labor charge.

Costs are divided into three general categories: variable cash costs (VC), fixed cash costs (FC), and economic costs (EC) (costs of owned resources). Subcategories within each are shown in Table 2. 
Table 2. Costs by category

\begin{tabular}{lll}
\hline Variable cash costs (VC) & Fixed cash costs (FC) & Economic (owned resources) costs (EC) \\
\hline Cuttings & Farm overhead & Labor \\
Seed & Interest on real estate & Land (excluding interest) \\
Fertilizers & Taxes and insurance & Nonland capital (interest on machinery) \\
$\quad$ Nitrogen & Interest on operating & Capital replacement (depreciation) \\
$\quad$ Phosphorus & Loans & \\
$\quad$ Potassium & & \\
$\quad$ Lime & & \\
Herbicides & & \\
Insecticides & \\
Fuel, lube, oil & \\
Machinery repairs & \\
Twine & \\
Soil testing & \\
Hired services & \\
$\quad$ custom harvesting & \\
$\quad$ custom planting & \\
\hline
\end{tabular}

These costs are calculated for each year of stand life and then discounted using the real discount rate back to time 0 . The same is done with crop yields. Discounted costs $\left\{\sum\left[\mathrm{VC}_{\mathrm{j}}+\right.\right.$ $\left.\left.\left.\mathrm{FC}_{\mathrm{j}}+\mathrm{EC}_{\mathrm{j}}\right) /(1+\mathrm{i})^{\mathrm{n}}\right]\right\}$ are divided by discounted yields $\left\{\sum\left[\left(\right.\right.\right.$ yield $\left.\left._{\mathrm{j}}(1+\mathrm{i})^{\mathrm{n}}\right]\right\}$ to get average crop price. (See Appendix D for a derivation of price. Discounted yields are an artifact of the mathematical process of setting discounted yields equal to discounted costs and solving for price, which is assumed to be constant.) Mathematically this is:

$$
\text { price }=\frac{\sum_{j=1}^{n}\left[\left(V C_{j}+F C_{j}+E C_{j}\right) /(1+i)^{j}\right]}{\sum_{j=1}^{n}\left[\text { yield }_{j} /(1+i)^{j}\right]}
$$

where: price $=$ average crop price,

$$
\begin{aligned}
& V C_{j}=\text { variable cash costs in year } j, \\
& F C_{j}=\text { fixed cash costs in year } j, \\
& E C_{j}=\text { economic costs in year } j, \\
& i=\text { real interest (discount) rate. }
\end{aligned}
$$

Cost data from different years are adjusted to 1995 dollars for use in the spreadsheet models and to 1999 dollars for use in this report. The adjustments are made using the Gross Domestic Product chain-type price deflator (Table 3). 
Table 3. Gross Domestic Product chain-type price deflator, 1990-1999

\begin{tabular}{|c|c|c|}
\hline Year & GNP price deflator & Ratio (GNP price deflator in year to 1995 ) \\
\hline 1999 & & $1.0600^{2}$ \\
\hline 1998 & 112.7 & $1.0483^{\circ}$ \\
\hline 1997 & 111.57 & 1.03776392894 \\
\hline 1996 & 109.54 & 1.01888196447 \\
\hline 1995 & 107.51 & 1 \\
\hline 1994 & 105.09 & 0.977490466 \\
\hline 1993 & 102.64 & 0.9547018882 \\
\hline 1992 & 100 & 0.93014603293 \\
\hline 1991 & 97.32 & 0.90521811924 \\
\hline 1990 & 93.64 & 0.87098874523 \\
\hline
\end{tabular}

astimated

${ }^{\text {bPreliminary }}$

Source: USDOC/BEA (1998)

\section{ACCOUNTING FOR SMALL TRACT SIZE}

Riparian buffer strips are likely to be small in size, 0.8 to 2.0 ha ( 2 to 5 acres). For fields ranging in size from 10.1 to 40.5 ha (25 to 100 acres), square in shape, with a $30-\mathrm{m}\left(100^{\prime}\right)$

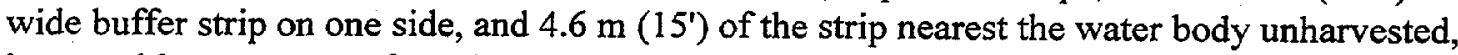
harvestable area ranges from 0.8 to $1.7 \mathrm{ha}$ ( 2.0 to 4.1 acres). Most crop budgets are designed for tracts much larger than 0.8 to 1.7 ha ( 2.0 to 4.1 acre). Therefore, to try to account for the small field size some adjustments are made and the results reported in the Summary and Conclusions. Otherwise costs reported are for larger tracts.

Not all time is spent with equipment operating at its theoretical rate. According to Hunt (1995), there are 10 time elements that need to be considered that involve labor associated with field operations:

1. Machine preparation time at the farm (e.g., removal from storage, attaching and unattaching implements from a tractor);

2. Travel time to and from field;

3. Machine preparation in the field;

4. Theoretical field time (i.e, time machine operating at optimum forward speed);

5. Turning time;

6. Loading and unloading;

7. Machine adjustment time (e.g., unplugging);

8. Maintenance time in field (e.g., refueling, lubrication, chain adjustment);

9. Repair time in field; and

10. Operator's personal time.

Elements 4 to 9 are included in the calculation of field efficiency. Field efficiency is the ratio of the time spent for elements 4 to the time spent for elements 4 to 9 . To account for time spent in elements 1 to 3 and 10, a factor of 1.2 of labor hours per machine hours is assumed. However, for small tracts the 1.2 factor will significantly underestimate time required for 1 to 3 and 10 . It is assumed that elements 1 to 3 and 10 require a minimum of 0.5 hours per hour of machine operation. For farmer operations (as opposed to custom operations) the labor hours to machine hours ratio is recalculated as: maximum [(machine hours +0.5$) /$ machine hours, 1.2]. 
For example, to spray herbicide with a boom sprayer requires 0.22 hours/ha ( 0.09 hours/acre). For a 0.81 ha (2 acre) tract calculate the labor hours to machine hours ratio as:

$$
\begin{gathered}
\text { maximum }[(0.81 * 0.22+0.5) /(0.81 * 0.22), 1.2]=3.78 \\
\text { maximum }[(2 * 0.09+0.5) /(2 * 0.9), 1.2]=3.78\} .
\end{gathered}
$$

For a 2.02 ha ( 5 acre) tract the ratio is 2.31 .

The calculation of the labor hours to machine hours ratio in this manner assumes there is no coordination between machine operations in the riparian buffer strip and adjacent fields. It could be, for example, that disking is done at the same time in buffer strip as in an adjacent field.

For custom harvest operations by full time custom operators, the calculation is done differently. In the field there is a labor hours to machine hours ratio of 1.2 , as for farmer operations. In addition it is assumed that each move from one tract to the next requires 1 hour. The labor hours to machine hours ratio is calculated as: (machine hours per tract $* 1.2+1) /($ machine hours per tract).

For harvesting willows, machine hours are based on the harvester [3.93 hours/ha (1.59 hours/

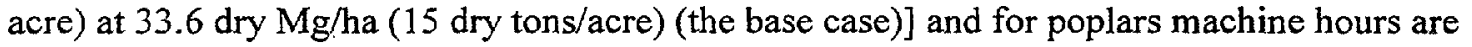
based on the chipper [ 11.2 hours/ha ( 4.55 hours/acre) at $112 \mathrm{dry} \mathrm{Mg} / \mathrm{ha} \mathrm{(50} \mathrm{dry} \mathrm{tons/acre),}$ 1345 trees/ha (545 trees/acre) (the base case)]. For a 0.81-ha (2-acre) tract, for willows the ratio is $\{(3.93 * 0.81 * 1.2+1) /(3.93 * 0.81=1.51[(1.59 * 2 * 1.2+1) /(1.59 * 2)=1.51]\}$ and for poplars is $\{(11.2 * 0.81 * 1.2+1) /(11.2 * 0.81)=1.31[(4.55 * 2 * 1.2+1) /(4.55 * 2)=1.31]\}$. For a 2.02-ha (5-acre) tract the ratios are 1.32 and 1.24 for willows and poplars, respectively.

\section{INPUT PRICES}

In 1998, cropland rental rates were $\$ 143.30 /$ ha $(\$ 58.00 /$ acre $)$ in Delaware and $\$ 135.80 /$ ha (\$55.00/acre) in Maryland (USDA/NASS 1998a). Rents for 1994 to 1998 are in Table 4. Pasture rent for 1994 to 1998 is only reported for Maryland in 1994, $\$ 82.70 /$ ha ( $\$ 33.50 /$ acre). Johnson and West (c. 1994) list data on land rents by region of Maryland for 1988 to 1992 and Jones (1997) lists rents for the whole state (Table 5). Of the five regions, the Upper Eastern Shore has the highest cash rents and the Lower Eastern Shore the second highest. From this data, average cropland rental rates are higher in the Delmarva Peninsula portion of Maryland than the rest of the state. In the Delmarva Peninsula it is assumed that cropland

Table 4. Cropland rental rates in Delaware and Maryland, 1994-1998

\begin{tabular}{ccccc}
\hline \multirow{2}{*}{ Year } & Delaware & Maryland & Delaware & Maryland \\
\cline { 2 - 5 } & \multicolumn{3}{c}{ \$/ha } & \multicolumn{2}{c}{ \$/acre } \\
\hline 1994 & 135.60 & 102.30 & 54.90 & 41.40 \\
1995 & 150.90 & 110.40 & 61.10 & 44.70 \\
1996 & 158.80 & 118.60 & 64.30 & 48.00 \\
1997 & 148.20 & 126.70 & 60.00 & 51.30 \\
1998 & 143.30 & 135.80 & 58.00 & 55.00 \\
\hline
\end{tabular}

Source: USDANASS (1998a) 
Table 5. Cropland rental rates for Maryland by region, 1988-1992

\begin{tabular}{|c|c|c|c|c|c|c|}
\hline Year & Maryland & $\begin{array}{c}\text { Lower } \\
\text { Eastern } \\
\text { Shore }\end{array}$ & $\begin{array}{c}\text { Upper } \\
\text { Eastern } \\
\text { Shore }\end{array}$ & $\begin{array}{l}\text { Southern } \\
\text { Maryland }\end{array}$ & Piedmont & $\begin{array}{l}\text { Western } \\
\text { Maryland }\end{array}$ \\
\hline & \multicolumn{6}{|c|}{$\$ /$ ha } \\
\hline 1988 & 124.75 & 124 & 143 & 62 & 111 & 64 \\
\hline 1989 & 136.10 & 119 & 131 & 72 & 106 & 69 \\
\hline 1990 & 121.75 & 109 & 121 & 67 & 109 & 74 \\
\hline 1991 & 131.65 & 111 & 121 & 67 & 114 & 74 \\
\hline 1992 & $\mathrm{NA}^{\mathrm{a}}$ & 111 & 126 & 72 & 116 & 74 \\
\hline \multirow[t]{2}{*}{$\begin{array}{c}\text { 1988-1991 } \\
\text { average }\end{array}$} & 128.55 & 115.45 & 129.05 & 66.70 & 109.90 & 70.40 \\
\hline & \multicolumn{6}{|c|}{ \$/acre } \\
\hline 1988 & 50.50 & 50 & 58 & 25 & 45 & 26 \\
\hline 1989 & 55.10 & 48 & 53 & 29 & 43 & 28 \\
\hline 1990 & 49.30 & 44 & 49 & 27 & 44 & 30 \\
\hline 1991 & 53.30 & 45 & 49 & 27 & 46 & 30 \\
\hline 1992 & $N A^{a}$ & 45 & 51 & 29 & 47 & 30 \\
\hline $\begin{array}{c}1988-1991 \\
\text { average }\end{array}$ & 52.05 & 46.75 & 52.25 & 27.00 & 44.50 & 28.50 \\
\hline
\end{tabular}

${ }^{2} \mathrm{NA}=$ not available.

Sources: Johnson and West (c. 1994), Jones (1997).

rents for $\$ 149.87 / \mathrm{ha}(\$ 60.67 / \mathrm{acre})(1999 \$)$ or $\$ 141.38 / \mathrm{ha}(\$ 57.24 / \mathrm{acre})(1995 \$)$ and pasture rents for $\$ 99.91 / \mathrm{ha}(\$ 40.45 /$ acre $)(1999 \$)$ or $\$ 94.26 / \mathrm{ha}$ (\$38.16/acre) $(1995 \$)$.

Input prices used are in Table 6 and machinery prices and parameters are in Table 7. (Table 7 in its equivalent English units is Table A.2 in Appendix A.) Machinery prices and parameters for poplar harvest equipment are in Table 8. Some operations such as tree planting and harvest are custom operations and are costed using total economic cost accounting. 
Table 6. Input prices (in 1995\$)

\begin{tabular}{|c|c|c|c|c|}
\hline Chemicals & Units & Price(\$/unit) & Units & Price(\$/unit) \\
\hline Potassium & $\mathrm{kg}$ & 0.362 & $\mathrm{lb}$ & 0.164 \\
\hline Phosphorus & $\mathrm{kg}$ & 1.444 & $\mathrm{lb}$ & 0.655 \\
\hline Nitrogen & $\mathrm{kg}$ & 0.679 & $\mathrm{lb}$ & 0.308 \\
\hline Lime (spread) & $\mathrm{Mg}$ & 29.32 & ton & 26.60 \\
\hline Glyphosate & $\mathrm{kg}$ & 29.82 & $\mathrm{lb}$ & 13.53 \\
\hline Simazine & $\mathrm{kg}$ & 10.03 & $\mathrm{lb}$ & 4.55 \\
\hline 2,4-D-amine & $\mathrm{kg}$ & 7.83 & $\mathrm{lb}$ & 3.55 \\
\hline Atrazine & $\mathrm{kg}$ & 7.94 & $\mathrm{lb}$ & 3.60 \\
\hline Linuron & $\mathrm{kg}$ & 48.06 & $\mathrm{lb}$ & 21.80 \\
\hline Insecticides & $\mathrm{kg}$ & 22.49 & $\mathrm{lb}$ & 10.20 \\
\hline \multicolumn{5}{|l|}{ Planting materials } \\
\hline Poplar cuttings & cutting & 0.16 & cutting & 0.16 \\
\hline Willow cuttings & cutting & 0.10 & cutting & 0.10 \\
\hline Switchgrass seed & $\mathrm{kg}$ & 4.41 & $\mathrm{lb}$ & 2.00 \\
\hline \multicolumn{5}{|l|}{ Other inputs } \\
\hline Diesel fuel & L & 0.244 & gal & 0.925 \\
\hline Diesel fuel - over-the-road & L & 0.346 & gal & 1.311 \\
\hline Oil & L & 1.31 & gal & 4.97 \\
\hline Soil testing & ha & 0.62 & acre & 0.25 \\
\hline \multicolumn{5}{|l|}{ Fixed cash inputs } \\
\hline Average farm overhead & ha & 19.27 & acre & 7.80 \\
\hline Average real estate interest & ha & 18.60 & acre & 7.53 \\
\hline Average taxes and insurance & ha & 41.94 & acre & 16.98 \\
\hline \multicolumn{5}{|l|}{ Economic costs } \\
\hline \multicolumn{5}{|l|}{ Labor } \\
\hline Hired agricultural & $\mathrm{hr}$ & 7.74 & $\mathrm{hr}$ & 7.74 \\
\hline Truck, harvest & $\mathrm{hr}$ & 14.40 & $\mathrm{hr}$ & 14.40 \\
\hline Mechanic, supervisor & $\mathrm{hr}$ & 18.00 & $\mathrm{hr}$ & 18.00 \\
\hline \multicolumn{5}{|l|}{ Land rent } \\
\hline Cropland-nonirrigated & ha & 141.38 & acre & 57.24 \\
\hline Pasture & ha & 94.26 & acre & 38.16 \\
\hline Interest rates & & Fraction & & Fraction \\
\hline Real machinery rate & & 0.065 & & 0.065 \\
\hline 6 month treasury rate & & 0.035 & & 0.035 \\
\hline Real discount rate & & 0.065 & & 0.065 \\
\hline
\end{tabular}


Table 7. Machinery prices and parameters (costs in 1995\$)

\begin{tabular}{|c|c|c|c|c|c|c|c|c|c|c|c|}
\hline Machine type & $\begin{array}{l}\text { Purchase } \\
\text { price }\end{array}$ & $\begin{array}{c}\text { Lifetime } \\
(\mathrm{hr})\end{array}$ & $\begin{array}{c}\text { Annual use } \\
\text { (hr) }\end{array}$ & Repair rates & $\begin{array}{c}\text { Speed } \\
(\mathrm{km} / \mathrm{hr})\end{array}$ & Width (m) & $\begin{array}{c}\text { Field } \\
\text { efficiency }\end{array}$ & $\begin{array}{c}\text { Hours/ } \\
\text { ha }\end{array}$ & $\begin{array}{c}\text { Lifetime } \\
\text { (years) }\end{array}$ & $\begin{array}{c}\text { Fuel use } \\
\text { (L/hr) }\end{array}$ & $\begin{array}{l}\text { Oil use } \\
\text { (L/hr) }\end{array}$ \\
\hline Moldboard plow, $6-41 \mathrm{~cm}$ & 10700 & 2000 & 200 & 100 & 7.24 & 2.44 & 0.85 & 0.67 & 10 & & \\
\hline Moldboard plow, $7-41 \mathrm{~cm}$ & 13800 & 2000 & 200 & 100 & 7.24 & 2.84 & 0.85 & 0.57 & 10 & & \\
\hline Chisel plow, $4.57 \mathrm{~m}$ & 6321 & 2000 & 200 & 75 & 8.05 & 4.57 & 0.85 & 0.32 & 10. & & \\
\hline Offset disk, $4.27 \mathrm{~m}$ & 8200 & 2000 & 200 & 60 & 9.66 & 4.27 & 0.8 & 0.3 & 10 & & \\
\hline Offset disk, $5.49 \mathrm{~m}$ & 10200 & 2000 & 200 & 60 & 9.66 & 5.49 & 0.8 & 0.25 & 10 & & \\
\hline Offset disk $6.40 \mathrm{~m}$ & 16900 & 2000 & 200 & 60 & 9.66 & 6.4 & 0.8 & 0.2 & 10 & & \\
\hline Fertilizer \& lime spreader, $3.6 \mathrm{Mg}, 12.2 \mathrm{~m}$ & 8000 & 1200 & 120 & 80 & 11.27 & 12.2 & 0.7 & 0.1 & 10 & & \\
\hline Grain drill, $7.62 \mathrm{~m}$ & 24900 & 1500 & 150 & 75 & 8.05 & 7.62 & 0.7 & 0.22 & 10 & & \\
\hline No-till drill (fertilizer attach), $4.57 \mathrm{~m}$ & 20500 & 1500 & 150 & 75 & 8.05 & 4.57 & 0.6 & 0.44 & 10 & & \\
\hline 4-row planter & 45000 & 1500 & 150 & 75 & & & & 1.65 & 10 & & \\
\hline Boom sprayer, $15.2 \mathrm{~m}$ & 4700 & 1500 & 150 & 70 & 4.83 & 15.24 & 0.6 & 0.22 & 10 & & \\
\hline Row cultivator, $2-91 \mathrm{~cm}$ & 2100 & 600 & 60 & 75 & 9.66 & 1.83 & 0.8 & 0.72 & 10 & & \\
\hline Mower, $2.13 \mathrm{~m}$, bushhog & 3500 & 2000 & 200 & 175 & 8.05 & 2.13 & 0.8 & 0.72 & 10 & & \\
\hline Mower-conditioner, $2.13 \mathrm{~m}$ & 7700 & 2500 & 250 & 80 & 7.24 & 2.13 & 0.8 & 0.82 & 10 & & \\
\hline Mower-conditioner, $3.66 \mathrm{~m}$ & 11700 & 2500 & 250 & 80 & 7.24 & 3.66 & 0.8 & 0.47 & 10 & & \\
\hline Side-delivery rake, $2.74 \mathrm{~m}$ & 3300 & 2500 & 250 & 60 & 9.66 & 2.74 & 0.8 & 0.47 & 10 & & \\
\hline Round baler, pto, $1.83 \mathrm{~m}$ diam, $1.22 \mathrm{~m}$ wide & 15480 & 1500 & 150 & 90 & 8.05 & 1.22 & 0.67 & 1.53 & 10 & & \\
\hline Round baler, pto, $<1.52 \mathrm{~m}$ diam, $1.22 \mathrm{~m}$ wide & 11300 & 1500 & 150 & 90 & 8.05 & 1.22 & 0.65 & 1.56 & 10 & & \\
\hline Bale carrier, forklift & 2700 & 1000 & 100 & 40 & & & & & 10 & & \\
\hline Claas Jaguar harvester & 300000 & 6400 & 800 & 40 & & & 0.7 & & 8 & 66.16 & 0.08 \\
\hline High dump forage wagon $\left(31.2 \mathrm{~m}^{3}\right)$ & 17739 & 2000 & 400 & 60 & & & & & 5 & & \\
\hline Tractor, $30 \mathrm{~kW}$ & 16900 & 10000 & 833.33333 & 100 & & & & & 12 & 7.48 & 0.053 \\
\hline Tractor, $45 \mathrm{~kW}$ & 21400 & 10000 & 833.33333 & 100 & & & & & 12 & 11.21 & 0.069 \\
\hline Tractor, $60 \mathrm{~kW}$ & 27500 & 10000 & 833.33333 & 100 & & & & & 12 & 14.95 & 0.085 \\
\hline Tractor, $75 \mathrm{~kW}$ (cab, air) & 40100 & 10000 & 833.33333 & 100 & & a & & & 12 & 18.69 & 0.1 \\
\hline Tractor, $90 \mathrm{~kW}$ (cab, air) & 55200 & 10000 & 833.33333 & 100 & & & & & 12 & 22.43 & 0.12 \\
\hline Tractor, $168 \mathrm{~kW}$, (cab, air) & 80500 & 10000 & 833.33333 & 100 & & & & & 12 & 42.06 & 0.2 \\
\hline Truck, $1.81 \mathrm{Mg}$, (hoist) & 45000 & 5000 & 500 & 60 & & & & & 10 & 14.19 & 0.13 \\
\hline Tandem truck (hay) & 52200 & 5000 & 500 & & & & & & 10 & 4.7 & 0.035 \\
\hline Fork lift & 15300 & 5000 & 500 & & & & & & 10 & 1.98 & \\
\hline Pickup & 18400 & 5000 & 500 & 60 & & & & & 10 & 2.25 & 0.028 \\
\hline Truck tractor (wood) & 81500 & 10000 & 1000 & & & & & & 10 & & \\
\hline Chip van & 29000 & 6000 & 300 & & & & & & 20 & & \\
\hline
\end{tabular}


Table 8. Machinery prices and parameters for poplar harvest equipment

\begin{tabular}{lccccccccccc}
\hline \multicolumn{1}{c}{ Equipment } & $\begin{array}{c}\text { Purchase } \\
\text { price } \\
(1995 \$)\end{array}$ & $\begin{array}{c}\text { Lifetime } \\
\text { (hrs) }\end{array}$ & $\begin{array}{c}\text { Lifetime } \\
\text { (yrs) }\end{array}$ & $\begin{array}{c}\text { Annual } \\
\text { use (hrs) }\end{array}$ & $\begin{array}{c}\text { Repair } \\
\text { rates }\end{array}$ & & \multicolumn{2}{c}{ Fuel use } & & Oil use \\
\hline Feller-buncher head & 35000 & 2000 & 4 & 500 & 80 & & & & & & \\
gal/hr & L/hr & gal/hr \\
CAT 518 skidder-120 HP & 130000 & 10000 & 5 & 2000 & 70 & 13.2 & 3.5004 & 0.11 & 0.029 \\
Chipper-400 HP & 175000 & 10000 & 5 & 2000 & 80 & 34.7 & 9.168 & 0.193 & 0.051 \\
\hline
\end{tabular}

\section{BIOMASS CROP YIELDS}

Costs are very sensitive to yields because a large fraction of costs do not change as yields change (e.g., establishment, land costs). Average hay yields (other than alfalfa and alfalfa mixtures) have averaged between 5.2 and $9.0 \mathrm{Mg} /$ ha-year (2.3 and 4.0 tons/acre-year) in Delaware from 1995 to 1997 (USDA/NASS 1998b). (The moisture content of this hay is probably about $15 \%$ ). When grown and managed specifically for biomass as opposed to forage quality, higher yields can be expected. Willows in the United States are still an experimental crop. In Sweden willows are grown as a commercial crop and yields average about 11.2 dry $\mathrm{Mg} /$ ha-year ( 5 dry tons/acre-year). In New York state yields are expected to range from 9.0 to 17.9 dry Mg/ha-year (4 to 8 dry tons/acre-year) (Kopp et al. 1997). Poplars as SRWC are being grown in the Pacific Northwest, Minnesota, and Mississippi. Minnesota is a better example for the Delmarva Peninsula than the Pacific Northwest. Expected poplar yields are in Minnesota on an $2.44 \mathrm{~m}$ x $2.44 \mathrm{~m}\left(8^{\prime} \times 8^{\prime}\right)$ spacing 1680 trees/ha (680 trees/acre) are 10.1 to $12.3 \mathrm{dry} \mathrm{Mg}$ /ha-year (4.5 to $5.5 \mathrm{dry}$ tons/acre-year) (personal communication, Mark Downing, Oak Ridge National Laboratory, Oak Ridge, TN, February 1, 1999).

In this study, 11.2 dry Mg/ha-year (5 dry tons/acre-year) is used as the baseline yield. Costs with yields of 9.0 and 13.4 dry Mg/ha-year (4 and 6 dry tons/acre-year) are also estimated. The range of 9.0 to $13.4 \mathrm{dry} \mathrm{Mg} /$ ha-year ( 4 to 6 dry tons/acre-year) represents a reasonable range of yields that can be expected for switchgrass, willow, and poplars. In examining some least cost scenarios in the conclusions, costs for higher yields are estimated.

For willow, yield at the first harvest (year 4) is $60 \%$ of mature yield. In the baseline only $20.1 \mathrm{dry} \mathrm{Mg} / \mathrm{ha}$ ( 9 dry tons/acre) is harvested in year 4 versus $33.6 \mathrm{dry} \mathrm{Mg} / \mathrm{ha}$ ( $15 \mathrm{dry}$ tons/acre) in all subsequent harvests. For switchgrass yield in year 1 is $30 \%$ and in year 2 is two-thirds of mature yield. In the baseline in year $1,3.36 \mathrm{dry} \mathrm{Mg} / \mathrm{ha}$ ( $1.5 \mathrm{dry}$ tons/acre $)$ and in year 2, $7.46 \mathrm{dry} \mathrm{Mg} / \mathrm{ha}$ (3.33 dry tons/acre) are harvested versus $11.2 \mathrm{dry} \mathrm{Mg} / \mathrm{ha}$ ( $5 \mathrm{dry}$ tons/acre) in all succeeding years.

\section{COSTS OF BIOMASS}

\section{WILLOW AT 15,300 TREES PER HA (6200 TREES PER ACRE)}

Site preparation takes place in the summer and fall preceding planting, if the site was previously in pasture, and in the spring of planting (Table 9). Willow cuttings cost $\$ 0.10 /$ cutting and mechanical planting costs $\$ 0.02 /$ cutting (Walsh and Becker 1996). Kopp et al. (1997) report willow cuttings cost $\$ 0.07 /$ cutting. A cost of $\$ 0.10 /$ cutting is used as the base case and costs are also determined for $\$ 0.07 /$ cutting. Mechanical tillage is assumed to be two diskings for land that was previously in cropland and moldboard plowing plus two diskings if the land was formerly in pasture. It may be that moldboard plowing is not an acceptable practice to establishment buffer strips, so a chisel plow could be substituted for a moldboard plow at a slightly lower cost. 
Table 9. Establishment practices for willow

\begin{tabular}{|c|c|}
\hline Cropland & Pasture \\
\hline \multicolumn{2}{|c|}{ Summer and/or fall (prior to planting) } \\
\hline No activities & $\begin{array}{l}\text { Herbicide [glyphosate } 2.24 \mathrm{~kg} \text { active ingredient } \\
\text { (a.i.)/ha }(2 \mathrm{lb} \text { a.i./acre })] \\
\text { moldboard plow }\end{array}$ \\
\hline \multicolumn{2}{|c|}{ Spring } \\
\hline \multicolumn{2}{|c|}{$\begin{array}{c}\text { Herbicide [glyphosate } 2.24 \mathrm{~kg} \text { active a.i./ha (2 lb a.i./acre) }] \\
\text { Disk (2 times) } \\
\text { Apply lime }[1.12 \mathrm{Mg} / \mathrm{ha}(1 \mathrm{ton} / \mathrm{acre})] \\
\text { Mechanical planting }[15,300 \mathrm{cuttings} / \mathrm{ha}(6200 \mathrm{cuttings} / \mathrm{acre})] \\
\text { Herbicide [simazine } 2.24 \mathrm{~kg} \text { active a.i./ha }(2 \mathrm{lb} \text { a.i./acre })]\end{array}$} \\
\hline
\end{tabular}

For herbicide use, glyphosate and simazine are assumed to be used for purposes of estimating costs. Simazine may not be the best herbicide to use after planting. While Goal [also at $2.24 \mathrm{~kg}$ active ingredient (a.i.)/ha ( $2 \mathrm{lb}$ a.i./acre)] is a possibility, based on experience with poplars in Minnesota a combination of Oust [70 g a.i./ha (1 oz a.i./acre)] and glyphosate [70 g a.i./ha ( 1 oz a.i./acre)] may be better (personal communication, Mark Downing, Oak Ridge National Laboratory, Oak Ridge, TN, February 1, 1999). The cost differential among these choices should be less than $\$ 25 /$ ha $(\$ 10 /$ acre).

No replanting is assumed. At the end of the first growing season, after leaf fall but before bud swell in the spring, a mower is used to cut down the willows to encourage coppicing. This promotes multiple stems growing from each cutting and should result in quick canopy closure during the second growing season (Kopp et al. 1997). After the establishment year, neither herbicide treatments nor mechanical weed control is assumed to be necessary.

Because of high soil nutrient levels after chicken litter has been applied to nearby fields over time, no applications of phosphorus and potassium are assumed. Lime to adjust $\mathrm{pH}$ is applied at $2.24 \mathrm{Mg} / \mathrm{ha}$ ( 1 ton/acre) at establishment. Assumed is a single application of nitrogen in the second growing season at $112 \mathrm{~kg} / \mathrm{ha}(100 \mathrm{lb} / \mathrm{acre})$. This may or may not be necessary. Application of nitrogen subsequent to harvest may or may not be necessary. None is assumed in the cost calculations other than in year 2.

Total establishment costs (1999\$) are \$2210/ha (\$895/acre) for cropland and \$2315/ha ( $\$ 935 /$ acre) for pasture. If a chisel plow is substituted for a moldboard plow on former pasture land, then establishment costs decrease slightly to $\$ 2300 /$ ha $(\$ 930 /$ acre).

Harvesting is critical to the success of willows for energy. In the harvested material $50 \%$ moisture on a wet weight basis is assumed. Some commercial harvesting is presently being done in Sweden. However, the reliability and effectiveness of harvesting equipment is somewhat tenuous. Because each stem is relatively small, modified forage or sugar cane harvesting equipment can be used. Similar to forage harvesting, equipment can be self propelled or operate off a tractor. For descriptions of harvesting equipment and experience with harvesting of short rotation woody crops (SRWC) stands see Hartsough and Yomogida (1996), and Kofman and Spinelli (1997), and Mitchell (1997).

There are many potential willow harvesters, many of which are experimental. Three of the more promising ones are: a Claas Jaguar forage harvester with a SRWC head; an Austoft 
sugar cane harvester with a SRWC head; and the Bender II from Salix Maskiner, a SRWC head mounted on a tractor (Table 10). All three are cut and chip harvesters.

Table 10. Willow harvesters

\begin{tabular}{lcccccc}
\hline \multirow{2}{*}{ Harvester } & \multicolumn{2}{c}{ Purchase price $^{\mathrm{a}}$} & \multicolumn{2}{c}{ Engine size $^{\mathrm{a}}$} & \multicolumn{2}{c}{ Cost per hour $^{\mathrm{b}}$} \\
\cline { 2 - 7 } & ECU & $\$$ & $\mathrm{~kW}$ & $\mathrm{hp}$ & $\mathrm{Dkr}$ & $\$$ \\
\hline \multirow{2}{*}{ Claas } & 234,000 & 262,000 & 260 & 349 & 1186 & 179 \\
& & & & & 2004 & 302 \\
\multirow{2}{*}{ Austoft } & 195,000 & 218,000 & 176 & 236 & 945 & 143 \\
& & & & & 1949 & 294 \\
Bender II & $107,000^{\mathrm{c}}$ & 120,000 & - $^{\mathrm{d}}$ & - & 937 & 141 \\
\hline
\end{tabular}

aSource: Mitchell (1997), converted at $\$ 1.12 / E C U$ (ECU is unit of currency used in the European Community)

'Source: Kofman and Spinelli (1997), converted at 6.63 Danish krone (Dkr)/\$, first cost is harvester only, second cost is harvester plus wagons.

'No cost listed for Bender II. Cost listed is for Bender III with Case Magnum 7120 tractor. Mitchell lists tractor as $150 \mathrm{~kW}(201 \mathrm{hp})$, but is $112 \mathrm{~kW}(150 \mathrm{hp})$ in literature.

'Listed in Mitchell with a $125 / 140 \mathrm{~kW}(168 / 188 \mathrm{hp})$ tractor. A $150 \mathrm{~kW}(201 \mathrm{hp})$ tractor is probably better.

The Claas Jaguar and Austoft harvesters are self propelled. The Claas Jaguar harvester [260 kW (349 hp)] is a wheeled forage harvester with a sugar cane head modified for SRWC. It can have problems in wet conditions (i.e., gets stuck in mud) and requires specific row spacing of trees for optimum harvest. The Austoft harvester [176 kW (236 hp)] is a modified sugar cane harvester with tracks instead of wheels. This allows it to operate under very wet conditions, but it cannot operate over public roads. However, if wagons are used to move chips from the harvester to chip van, they would also need to be tracked to avoid getting stuck in wet conditions. There are indications that the Austoft could use a larger engine (Mitchell 1997). The third is a head from Salix Maskiner (called the Bender) designed to attach to the front of a tractor [minimum of $101 \mathrm{~kW}(135 \mathrm{hp})$, better at $149 \mathrm{~kW}(200 \mathrm{hp})$ ] to harvest SRWC. The Bender is of interest because a relatively low cost head (probably $\$ 30,000-\$ 50,000$ ) can be used on an existing relatively high powered tractor. The Austoft and Claas harvesters are expensive and would only be used by custom harvest operators. The Salix Maskiner head could potentially be used by individual farmers.

Improvements are needed in willow harvesting equipment. These include improving the mechanical reliability of the harvesting head and the quality of the chips.

Walsh and Becker (1996) have cost information on the Claas Jaguar harvester (Table 7). The Jaguar is a standard $260 \mathrm{~kW}$ (349 hp) forage harvester with a head modified for use with SRWC and augmented hydraulic capacity. It is an expensive machine, costing $\$ 300,000$ $(1995 \$)$. However it is also possible to use the base forage harvester with different heads to harvest forage crops. It is designed to harvest two rows at a time that are spaced $0.75 \mathrm{~m}\left(2.5^{\prime}\right)$ apart. Time required to harvest a ha (acre) varies with yield harvested. At $33.6 \mathrm{dry} \mathrm{Mg} / \mathrm{ha}$ (15 dry tons/acre), the harvester requires 3.93 hours/ha (1.59 hours/acre), or it harvests 8.55 $\mathrm{dry} \mathrm{Mg} /$ hour ( $9.43 \mathrm{dry}$ tons/hour). Often it is assumed that a harvester will use two wagons and one or two tractors to forward chips to a chip van, with one wagon being filled while the other travels to and from the chip van and unloads. However, in this report, only a single wagon attached to the harvester is modeled and no tractor shuttle is assumed. The harvester 
pulls a $31.1 \mathrm{~m}^{3}\left(1100 \mathrm{ft}^{3}\right)$ high dump forage wagon [capacity of $4.49 \mathrm{dry} \mathrm{Mg}$ at $144 \mathrm{dry} \mathrm{kg} / \mathrm{m}^{3}$ ( 4.95 dry tons at $\left.9.0 \mathrm{dry} \mathrm{lb} / \mathrm{ft}^{3}\right)$ ]. The wagon has a scale and a dumping time of 1 minute.

[For more information on high dump forage wagons see Turhollow et al. (1998).] A truck tractor with a chip van, capacity of $22.7 \mathrm{Mg}$ (11.3 dry $\mathrm{Mg}$ ) [25 tons (12.5 dry tons)], is used to transport the wood chips. It is assumed that the chip van is located at the edge of the tract being harvested. Three forage wagon loads of $7.56 \mathrm{Mg}$ (3.78 dry Mg) [8.33 tons (4.17 dry tons)] fills a chip van. So it is assumed that a forage wagon is filled to only $7.56 \mathrm{Mg}$ ( 8.33 tons) or $84 \%$ of capacity. Only 2.26 loads are required per hour of harvest. When the forage wagon reaches $7.56 \mathrm{Mg}$ (8.33 tons), the forage harvester takes it to the chip van and dumps its load into the chip van. As long as the distance that the forage harvester has to travel is not too long, this system works well. The system modeled minimizes equipment and labor required. Cost (1999\$) for this harvest system is $\$ 24 /$ dry $\mathrm{Mg}(\$ 22 / \mathrm{dry}$ ton). If the physical configuration of the area harvested is favorable, when the harvester reaches the end of the rows it is harvesting near the chip van and has reached a load of approximately. $7.56 \mathrm{Mg}$ ( 8.33 tons), then travel distance is minimal. If the travel distance is long, then a shuttle system using two wagons is less costly.

The truck tractor is assumed to be in motion most of the day, driving between harvesting sites and where the wood chips are utilized. Because the time required to load a chip van is about 1.5 hours, it is assumed that the truck tractor unhitches the empty van and then hitches a full van at that site or goes to another site and hitches and takes the full van to the site where the chips are used. An average round trip length is assumed to be $80 \mathrm{~km}$ (50 miles), an average round trip takes 1.8 hours for the truck tractor, and each truck tractor services three chip vans. The use of three chip vans per truck tractor is reflected in the number of hours of annual use of chip vans. Some of the truck costing parameters are in Table 7. Average transportation cost (1999\$) is $\$ 12 /$ dry $\mathrm{Mg}$ ( $\$ 11 /$ dry ton).

Stump removal costs at the end of the stand's life are included in costs. These are estimated to be $\$ 146 / \mathrm{ha}$ ( $\$ 59 / \mathrm{acre}$ ). Amortized over all willow production, these costs range from only $\$ 0.36 / \mathrm{dry} \mathrm{Mg}$ ( $\$ 0.33 /$ dry ton) (22-year stand life) to $\$ 1.43 / \mathrm{dry} \mathrm{Mg}$ ( $\$ 1.30 / \mathrm{dry}$ ton) (10-year stand life).

Costs are for delivered biomass [i.e., they include the $\$ 12 /$ dry $\mathrm{Mg}(\$ 11 / \mathrm{dry}$ ton) transportation cost]. Costs are determined for stands that last $10,13,16,19$, and 22 years. For willow on cropland put into riparian buffer strips, with an average mature yield of $11.2 \mathrm{dry} \mathrm{Mg} /$ ha-year (5 dry tons/acre-year), costs (total costs, costs if payments to landowners are made as in the CRP program, and costs if payments are made as in the enhanced CRP program) are shown in Fig. 2. Total costs (1999\$) at equal yields are only slightly lower for pasture than cropland, by about $\$ 4 / \mathrm{dry} \mathrm{Mg}$ ( $\$ 4 /$ dry ton), because of lower land costs. However, land that has been in pasture is probably lower yielding than cropland. With willow grown on land formerly in pasture, with a yield $90 \%$ of yield on cropland, willow on former pastureland is more expensive, by $\$ 2$ to $\$ 4 / \mathrm{dry} \mathrm{Mg}$ ( $\$ 2$ to $\$ 4 / \mathrm{dry}$ ton). Looking at total costs, costs per dry ton are fairly high, between $\$ 84$ and $\$ 108 /$ dry $\mathrm{Mg}(\$ 76$ and $\$ 98 /$ dry ton). Receiving payments as from the CRP program reduces costs substantially, to $\$ 60$ to $\$ 75 /$ dry $\mathrm{Mg}$ ( $\$ 54$ to $\$ 68 /$ dry ton). The enhanced CRP program payments reduce costs to $\$ 40$ to $\$ 49 / \mathrm{dry} \mathrm{Mg}$ ( $\$ 37$ to $\$ 44 / \mathrm{dry}$ ton). Extending the stand life from 10 years has a significant impact on total costs per dry ton of willow, but has only a minor impact under the enhanced CRP (Fig.1). This is because extending stand life amortizes establishment costs over a longer 


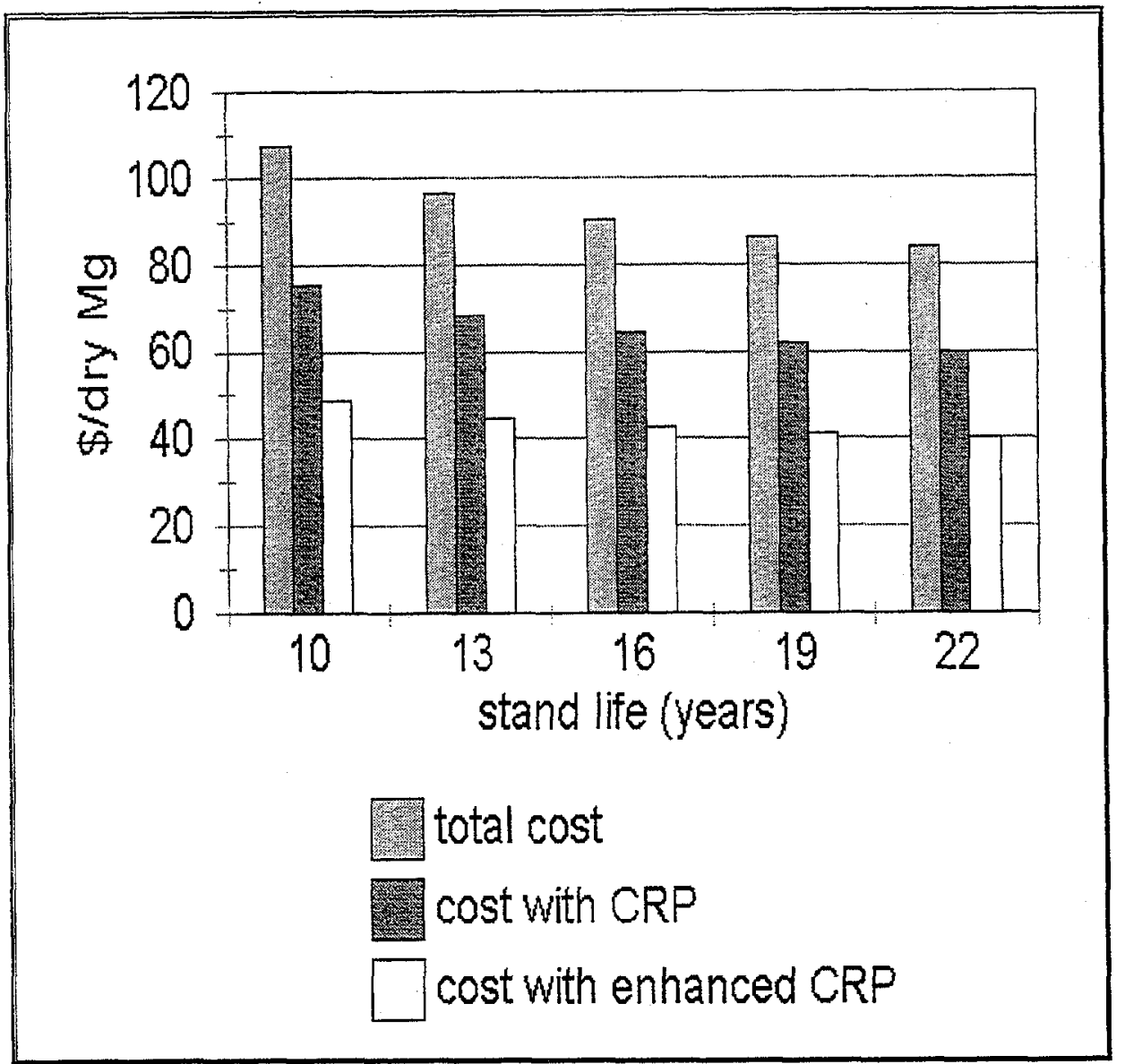

Fig. 2. Delivered costs (1999S) of willow chips with no payments (total costs), CRP payments, and enhanced CRP payments [mature yield $=\mathbf{1 1 . 2}$ dry Mg/ha-year (5 dry tons/acre-year)].

period. However, under the enhanced CRP, only $5 \%$ of establishment costs are borne by the farmer. Note that the largest portions of total economic costs (about 75\%) are for cuttings, harvest and land (Fig. 3).

Yields impact costs (Fig. 4). For a 19-year stand life, total costs for willow delivered to the place of use decrease from $\$ 103 / \mathrm{dry} \mathrm{Mg}$ ( $\$ 94 / \mathrm{dry}$ ton) to $\$ 76 / \mathrm{dry} \mathrm{Mg}(\$ 69 / \mathrm{dry}$ ton) as mature yield increases from 9.0 to $13.4 \mathrm{dry} \mathrm{Mg} / \mathrm{ha}$-year (4 to $6 \mathrm{dry}$ tons/acre-year). As payments increase, the impact of yield on costs decrease. Under the enhanced CRP delivered costs are in the $\$ 38$ to $\$ 46 /$ dry $\mathrm{Mg}(\$ 34$ to $\$ 42 /$ dry ton) range. 


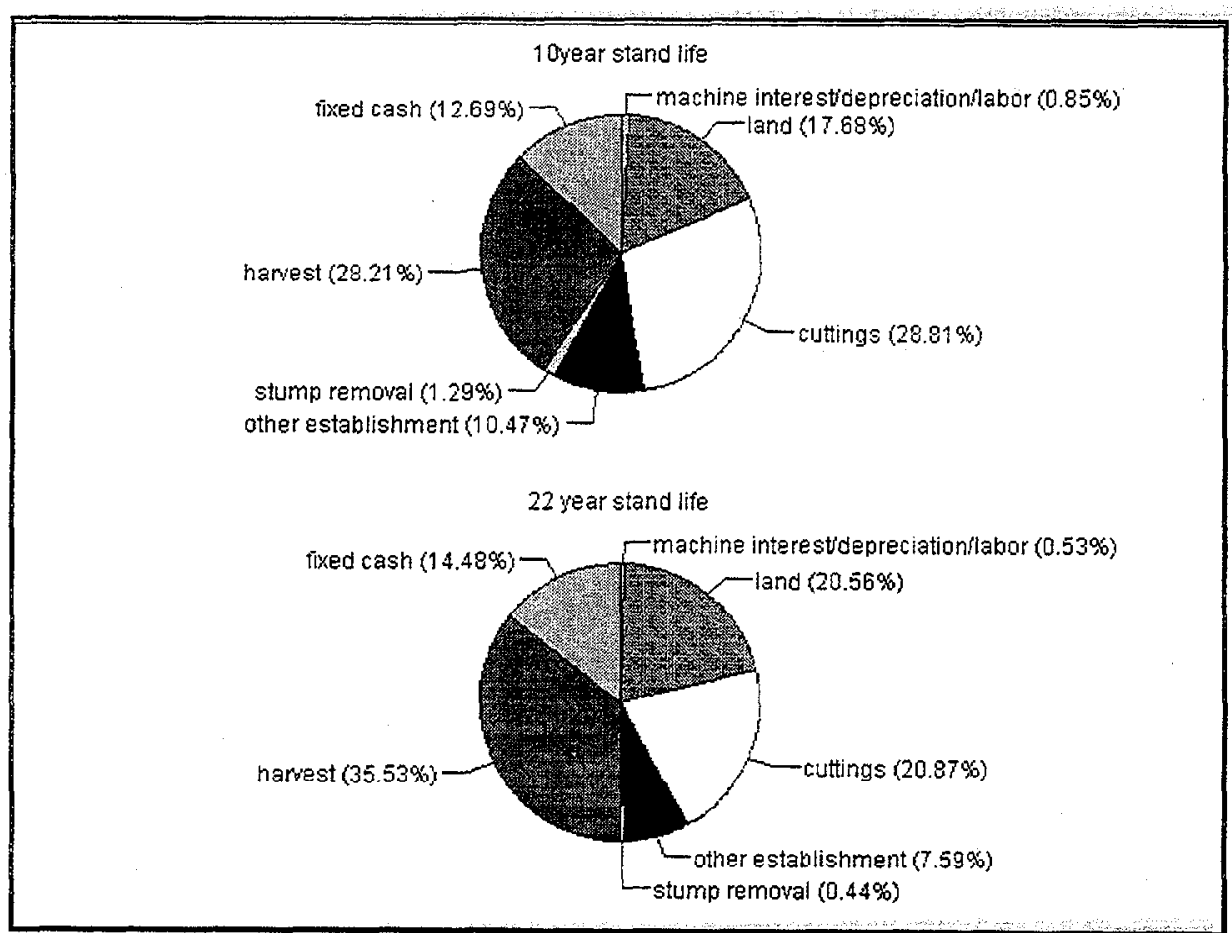

Fig. 3. Percent of farm gate willow costs by activity for 10 and 22 year stand lives [mature yield $=\mathbf{1 1 . 2} \mathrm{dry} \mathrm{Mg} / \mathrm{ha}$-year ( $5 \mathrm{dry}$ tons/acre-year)]

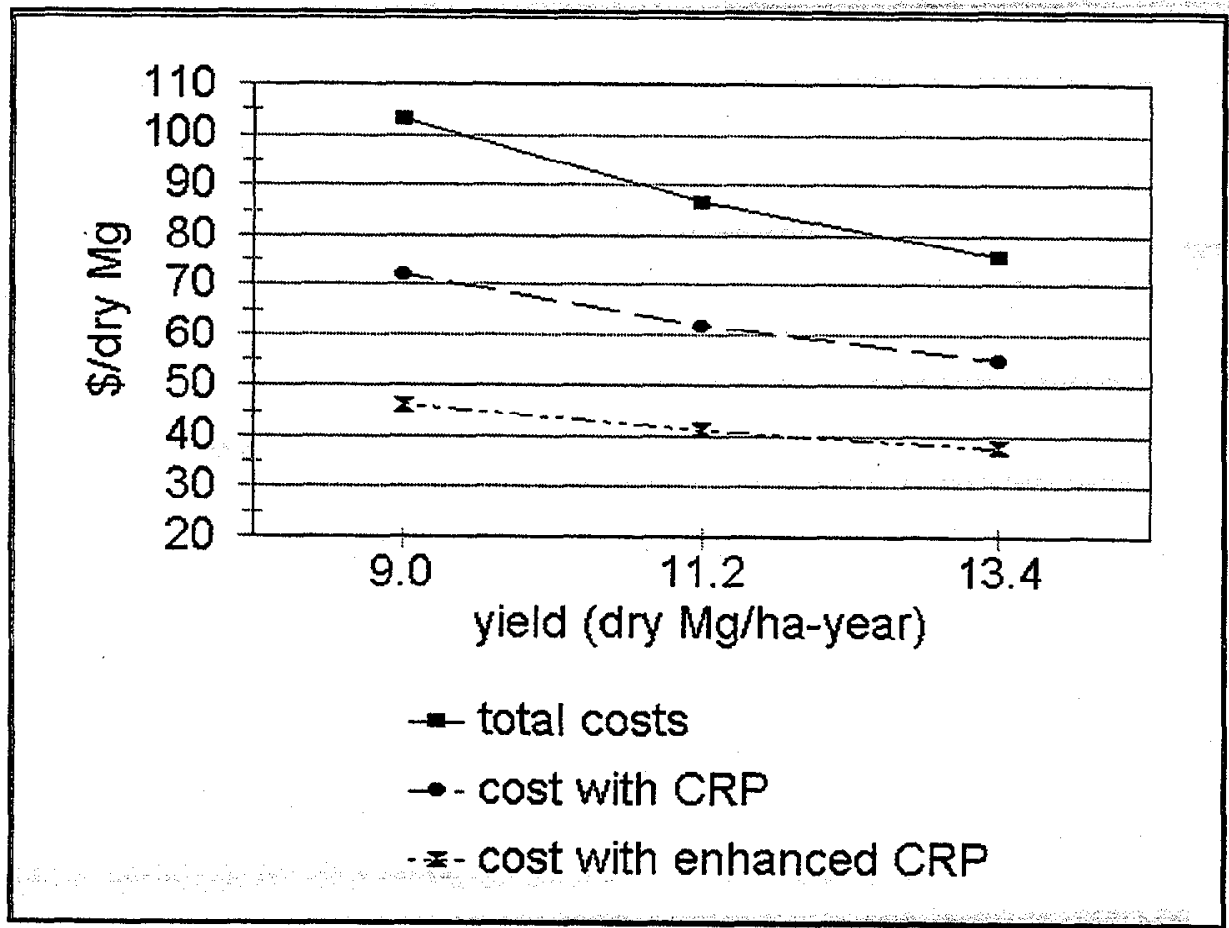

Fig. 4.. Impact of yields on delivered willow cost (1999\$), based on 19 year stand life. 
If cuttings cost only $\$ 0.07 /$ cutting instead of $\$ 0.10 /$ cutting, then for a 19-year stand life and a yield of 11.2 dry Mg/ha-year (5 dry tons/acre-year), total costs (costs for $\$ 0.10 /$ cutting in parentheses) are $\$ 82(\$ 87) / \mathrm{dry} \mathrm{Mg}$ [ $\$ 74(\$ 79) /$ dry ton], with CRP payments costs are $\$ 57$ $(\$ 62)) /$ dry $M g[\$ 51(\$ 56) /$ dry ton], and for enhanced CRP payments costs are $\$ 36(\$ 41) /$ dry $\mathrm{Mg}[\$ 33(\$ 37) /$ dry ton].

\section{POPLARS}

Poplars are being planted at wider spacings than willows, $2.44 \mathrm{~m} \times 3.05 \mathrm{~m}\left(8^{\prime} \times 10^{\prime}\right)$ or $2.44 \mathrm{~m} \times 2.44 \mathrm{~m}\left(8^{\prime} \times 8^{\prime}\right)$ [1345 or 1680 trees/ha (545 or 680 trees/acre). They are harvested at about 6 to 10 years, because this spacing and maturity results in a higher wood-to-bark ratio and better quality wood chips. In this analysis, harvest is assumed to occur at 10 years of age and there is no coppice regrowth. Such spacing results in significantly lower establishment costs than willows but, because of tree size at harvest due to both spacing and tree age, requires the use of conventional forestry equipment for harvesting.

Poplar establishment practices are listed in Table 11. Field preparation is similar to willows. Planting is done by hand. Poplar cuttings cost more than willow cuttings $(\$ 0.16$ versus $\$ 0.10$ ) and hand planting (as is done for poplar cuttings) is more expensive than machine planting (as is done for willow cuttings) ( $\$ 0.08 /$ cutting versus $\$ 0.02 /$ cutting). Because of the wider spacings, weed control must be practiced into the third year. Glyphosate and linuron are not necessarily the best combination of herbicides to use, but are used to estimate the costs of using herbicides for poplar.

Table 11. Poplar establishment practices

\begin{tabular}{|c|c|}
\hline Cropland & Pasture \\
\hline \multicolumn{2}{|c|}{ Establishment year } \\
\hline $\begin{array}{c}\text { Disk (2 times) } \\
\text { Herbicide in fall [glyphosate } 4.48 \mathrm{~kg} \text { a.i./ha (2 lb } \\
\text { a.i./acre)] } \\
\text { Apply lime [1.12 Mg/ha (1 ton/acre)] } \\
\text { Hand plant [1345 cuttings/ha (545 } \\
\text { cuttings/acre)] } \\
\text { Herbicide [linuron } 1.68 \mathrm{~kg} \text { a.i./ha (1.5 lb } \\
\text { a.i./acre)] } \\
\text { Mechanical cultivation (3 times) }\end{array}$ & $\begin{array}{c}\text { Herbicide in fall [glyphosate } 4.48 \mathrm{~kg} \text { a.i./ha (2 lb } \\
\text { a.i./acre)] } \\
\text { Moldboard plow } \\
\text { Disk (2 times) } \\
\text { Apply lime [1.12 Mg/ha (1 ton/acre)] } \\
\text { Hand plant [ } 1345 \text { cuttings/ha }(545 \\
\text { cuttings/acre)] } \\
\text { Herbicide [linuron } 1.68 \mathrm{~kg} \text { a.i./ha (1.5 lb } \\
\text { a.i./acre)] } \\
\text { Mechanical cultivation (3 times) }\end{array}$ \\
\hline \multicolumn{2}{|c|}{ Year 2} \\
\hline \multicolumn{2}{|c|}{ Mechanical cultivation ( 2 times) } \\
\hline \multicolumn{2}{|c|}{ Year 3} \\
\hline \multicolumn{2}{|c|}{ Mechanical cultivation ( 1 time) } \\
\hline
\end{tabular}

Harvest uses a feller-buncher head on a $75-\mathrm{kW}(100-\mathrm{hp})$ tractor to sever trees, gather a multiple number of trees together, then drop them on the ground; two skidders to move the 
trees from the field to the chipper; and a chipper to make chips from trees and blow the chips into a chip van. The feller-buncher and skidders are oversized and more rugged than required to harvest short-rotation poplar. At a $45 \mathrm{dry} \mathrm{Mg/ha} \mathrm{(50} \mathrm{dry} \mathrm{tons/acre)} \mathrm{harvest} \mathrm{at} 10$ years, two skidders [20.8 hours/ha ( 8.44 hours/acre) each] approximately equal the productivity of the chipper [11.24 hours/ha (4.55 hours/acre)]. The feller-buncher requires only 1.98 hours/ha ( 0.80 hours/acre). A flatbed truck is used to transport the harvest equipment and costs $\$ 45,000$. This complement is expensive, with a purchase price of $\$ 550,000$. Such a complement is suitable only for a custom operator.

Presently poplars planted at a density of 1345 or 1680 trees/ha (545 or 680 trees/acre) are not being allowed to regrow by coppice after harvest, in part because multiple stems from coppice regrowth would result in a higher bark-to-wood ratio. This is not a concern for energy, so it may be desirable to allow coppice regrowth.

For this analysis, a density of 1345 trees/ha ( 545 trees/acre) is assumed. Total establishment costs are $\$ 745 / \mathrm{ha}$ ( $\$ 300 /$ acre) on former cropland and $\$ 770 / \mathrm{ha}$ ( $\$ 310 /$ acre) on former pasture. Use of a chisel plow instead of a moldboard plow on former pasture reduces establishment costs by $\$ 15 / \mathrm{ha}$ ( $\$ 6 /$ acre). Establishment costs for poplars are significantly less than for willows. At a 11.2 dry Mg/ha-year (5 dry tons/acre-year) yield for a 10-year stand life with no coppice regrowth, total delivered costs are $\$ 76 /$ dry $\mathrm{Mg}(\$ 69 / \mathrm{dry}$ ton) [ $\$ 3.80 / \mathrm{GJ}$ $(\$ 4.05 / \mathrm{million} B t u)]$. The included transportation cost is the same as for willows, $\$ 12 / \mathrm{dry} \mathrm{Mg}$ (\$11/dry ton). With CRP payments, costs are $\$ 52 /$ dry $\mathrm{Mg}(\$ 47 /$ dry ton) and with enhanced CRP payments, costs are $\$ 33 /$ dry $\mathrm{Mg}(\$ 30 /$ dry ton) (Fig. 5 ).

The largest portions of costs are for harvest (37\%) and land 25\% (Fig. 6). Yield impacts on total delivered costs are in Fig. 7. Total delivered costs decrease from $\$ 88 / \mathrm{dry} \mathrm{Mg}$ ( $\$ 80 /$ dry ton) at $9.0 \mathrm{dry} \mathrm{Mg/ha-year} \mathrm{(4} \mathrm{dry} \mathrm{tons/acre-year)} \mathrm{to} \$ 67 / \mathrm{dry} \mathrm{Mg}(\$ 61 / \mathrm{dry}$ ton) at 13.4 dry $\mathrm{Mg} /$ ha-year ( 6 dry tons/acre-year). With enhanced CRP payments costs range from $\$ 32$ to $\$ 36 /$ dry Mg ( $\$ 29$ to $\$ 32 /$ dry ton). The yield impact is relatively minor with enhanced CRP payments.

If the cost of cuttings decreases from $\$ 0.16$ to $\$ 0.10$ and planting costs from $\$ 0.08$ to $\$ 0.05 /$ cutting, total costs decrease by $\$ 2 / \mathrm{dry} \mathrm{Mg}$ (\$2/dry ton). If poplar is planted on pastureland with its associated lower land rent (two-thirds of cropland) and yield is $90 \%$ of that on cropland, then total costs are nearly identical to poplar on cropland.

\section{SWITCHGRASS}

Two sizes of machinery complements to produce switchgrass are costed, large scale and small scale. Costs differ little between these two complements. Site preparation for switchgrass can start in the fall preceding planting or in the spring of planting. Establishment activities for cropland are shown in Table 12.

Table 12. Establishment activities for switchgrass on cropland

Disk or disk harrow (1 time)

Herbicide [2, 4-D $1.12 \mathrm{~kg}$ a.i./ha (1 lb a.i./acre)]

Herbicide [Atrazine $2.24 \mathrm{~kg}$ a.i./ha (2 lb a.i./acre)]

Apply lime [4.48 Mg/ha (2 tons/acre)]

Plant seed with grain drill (15\% replant rate) 


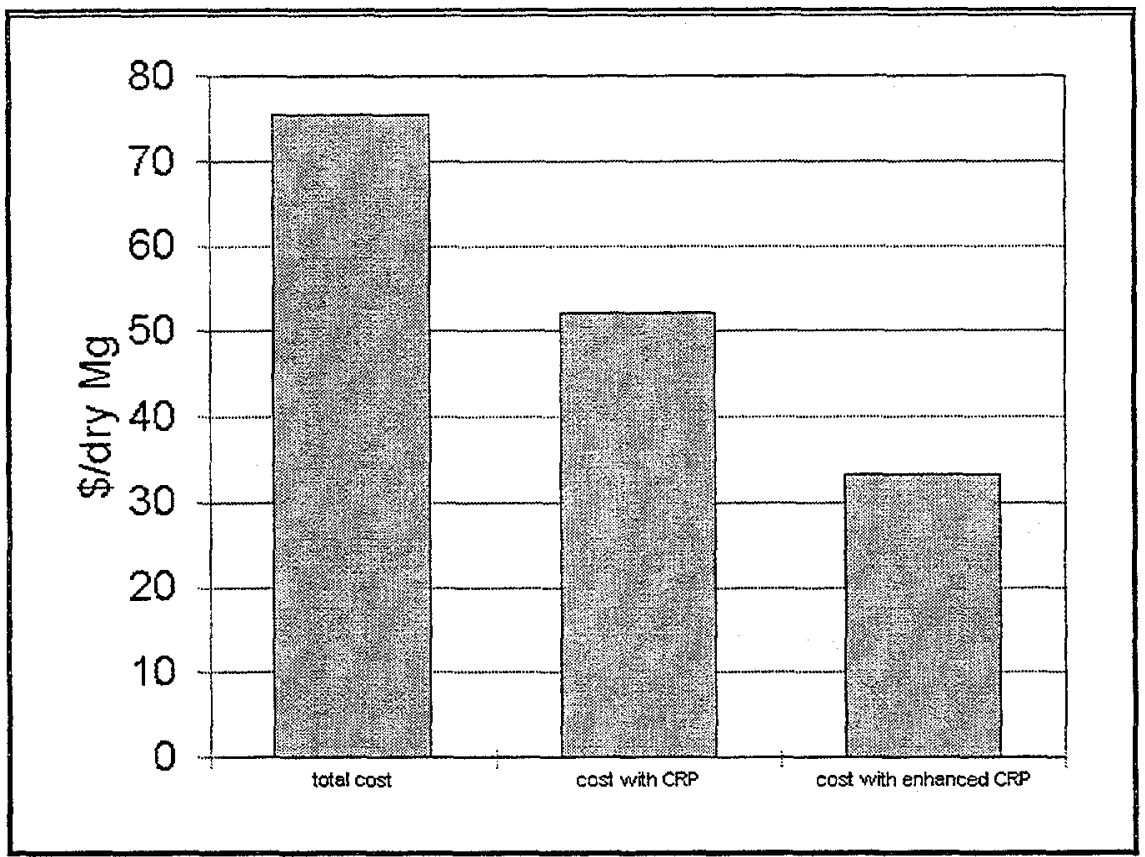

Fig. 5. Costs (1999\$) of poplar chips with no payments (total costs), CRP payments, and enhanced CRP payments [mature yield $=\mathbf{1 1 . 2}$ dry $\mathrm{Mg} / \mathrm{ha}$-year ( 5 dry tons/acre-year)].

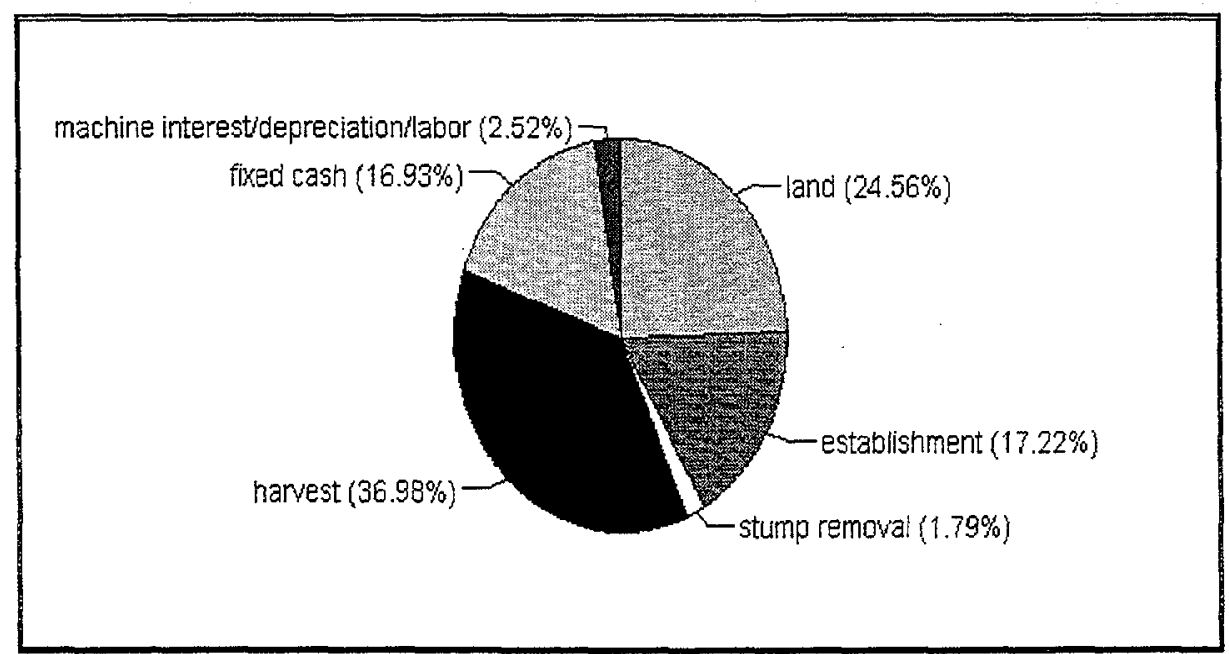

Fig. 6. Percent of farm gate poplar costs by type [mature yield $=\mathbf{1 1 . 2}$ dry Mg/ha-year (5 dry tons/acre-year)]. 


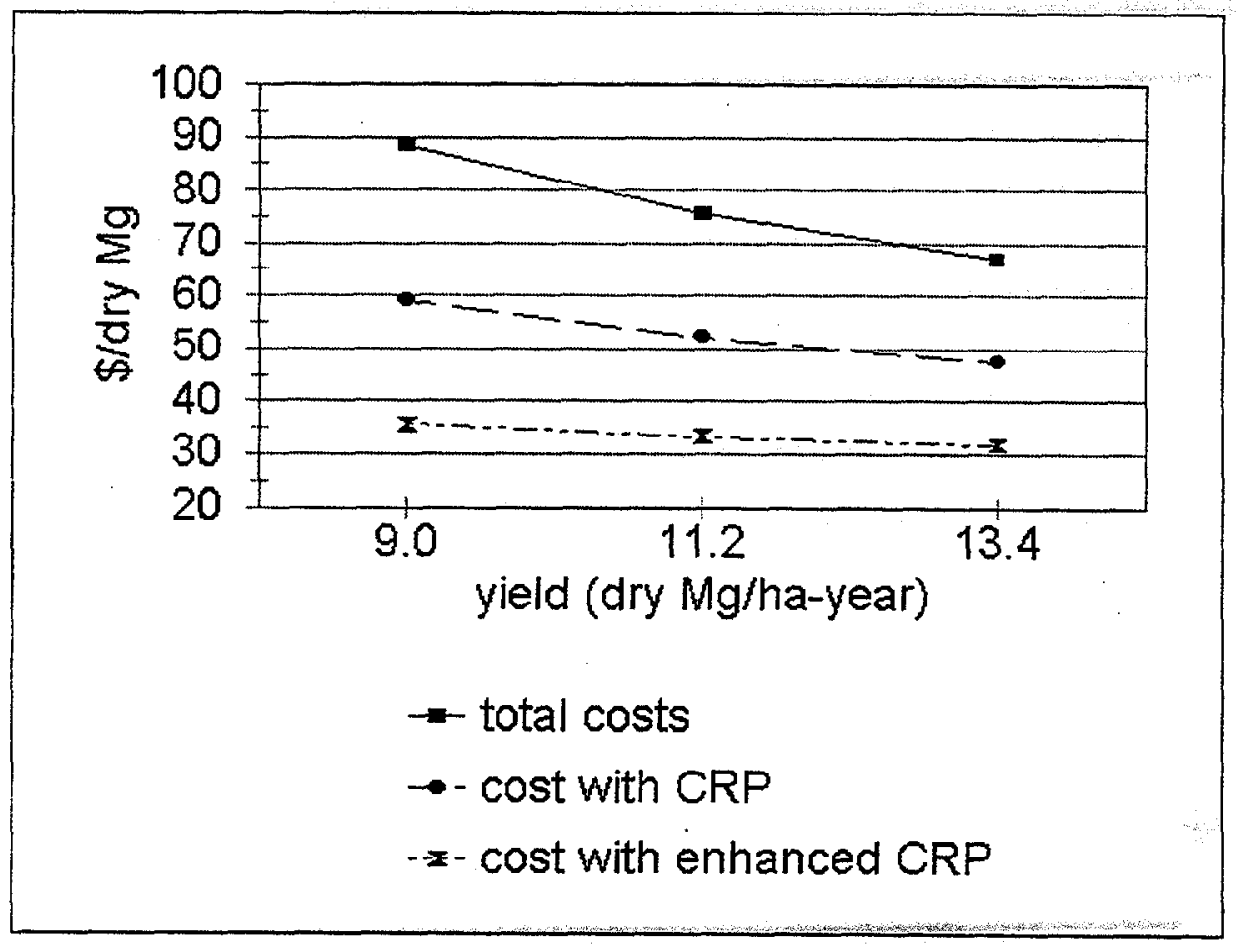

Fig. 7. Impact of yields on delivered poplar cost (1995\&).

Establishment costs for large and small scale machinery complements differ by less than $\$ 1 /$ ha $(\$ 1 /$ acre). Total establishment costs $(1999 \$)$ are about $\$ 240 /$ ha $(\$ 100 /$ acre), only $11 \%$ of those for willow. Stands are assumed to exist for 10 years.

Because of high soil nutrient levels, no potassium or phosphorus is assumed to be applied and no nitrogen is applied in the establishment year. Nitrogen is applied in subsequent years at $101 \mathrm{~kg} / \mathrm{ha}(90 \mathrm{lb} / \mathrm{acre})$. This nitrogen application may or may not be necessary. Lime is applied at $4.5 \mathrm{Mg} / \mathrm{ha}$ (2 tons/acre) at establishment.

Harvesting of switchgrass is done with conventional hay balers. The large scale equipment complement uses a large round baler that makes $1.22 \mathrm{~m}\left(4^{\prime}\right)$ wide bales $1.83 \mathrm{~m} \mathrm{(6^{ \prime } )}$ in diameter, weighing $510 \mathrm{~kg}(1125 \mathrm{lb})$ on a wet basis. The small-scale equipment complement uses a large round baler that makes $1.22 \mathrm{~m}\left(4^{\prime}\right)$ wide bales $1.52 \mathrm{~m}\left(5^{\prime}\right)$ in diameter weighing $354 \mathrm{~kg}(781 \mathrm{lb})$ on a wet basis. Dry matter content is assumed to be $88 \%$. Bales are moved to the field edge by a tractor with bale carriers on each end. A tractor thus equipped can move 10 bales/hour. Harvesting costs (1999\$) are around $\$ 17 /$ dry Mg $(\$ 16 /$ dry ton).

Bales are moved from the field edge to the facility where they are utilized, by a tandem truck with a 14.6-m (48') trailer which carries a fork lift to load bales on the truck. The truck driver is assumed to operate the fork lift. The truck makes three round trips per eight-hour day. Transportation costs (1999\$) for $1.82 \mathrm{~m}\left(6^{\prime}\right)$ diameter bales are $\$ 6.50 / \mathrm{dry} \mathrm{Mg}(\$ 5.90 / \mathrm{dry}$ ton) and for $1.52 \mathrm{~m}\left(5^{\prime}\right)$ diameter bales are $\$ 8.30 / \mathrm{dry} \mathrm{Mg}(\$ 7.55 / \mathrm{dry}$ ton). 
Delivered costs (1999\$) for switchgrass in $1.83 \mathrm{~m}\left(6^{\prime}\right)$ diameter bales; total costs, costs with CRP payments, and costs with enhanced CRP payments, for a mature yield of 11.2 dry $\mathrm{Mg} / \mathrm{ha}$-year (5 dry tons/acre-year) are shown in Fig. 8. Total delivered costs are $\$ 57 / \mathrm{dry} \mathrm{Mg}$ ( $\$ 52 /$ dry ton) and decrease to $\$ 40 /$ dry $\mathrm{Mg}(\$ 37 /$ dry ton) with CRP payments and $\$ 30 /$ dry $\mathrm{Mg}$ ( $\$ 27 /$ dry ton) with enhanced CRP payments. Yield affects the cost of switchgrass as shown in Fig. 9. While yield significantly impacts total costs with no program payments, yield only has a minor impact on delivered costs when switchgrass receives enhanced CRP payments.

The distribution of costs for switchgrass (Fig. 10) is quite different than for willow (Fig. 3).

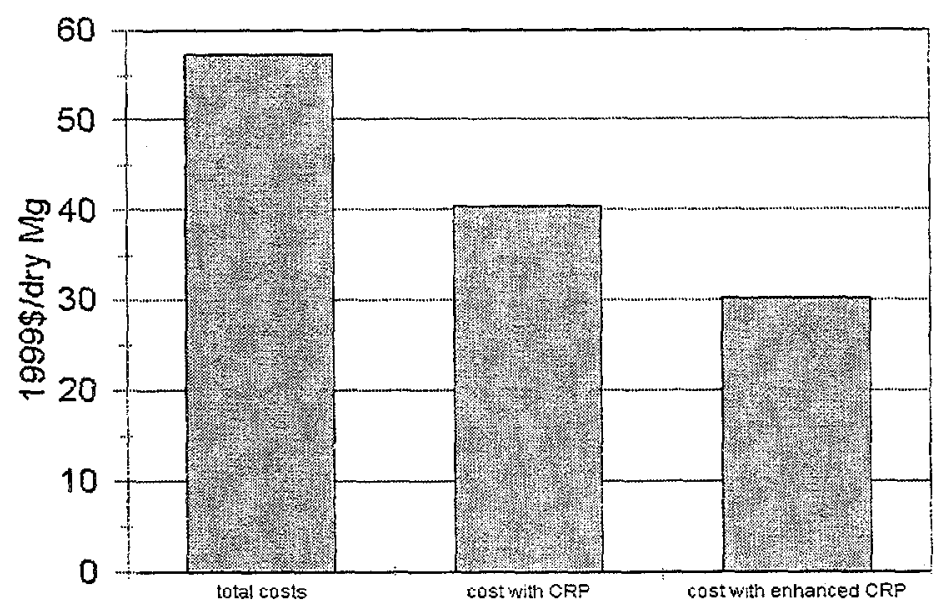

Fig. 8. Costs (1999\$) of switchgrass bales with no payments (total costs), CRP payments, and enhanced CRP payments [mature yield $=11.2 \mathrm{dry} \mathrm{Mg} / \mathrm{ha}$-year (5 dry tons/acre-year)] .

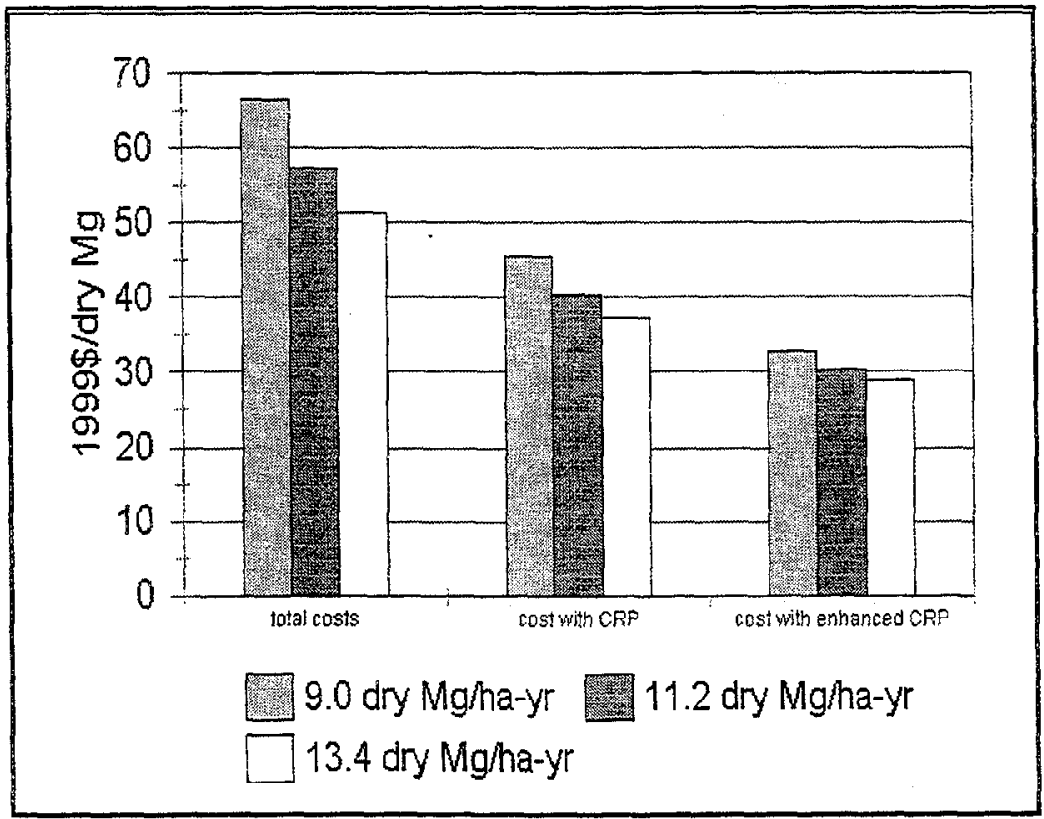

Fig. 9. Impact of yield on delivered switchgrass costs (1999\$). 


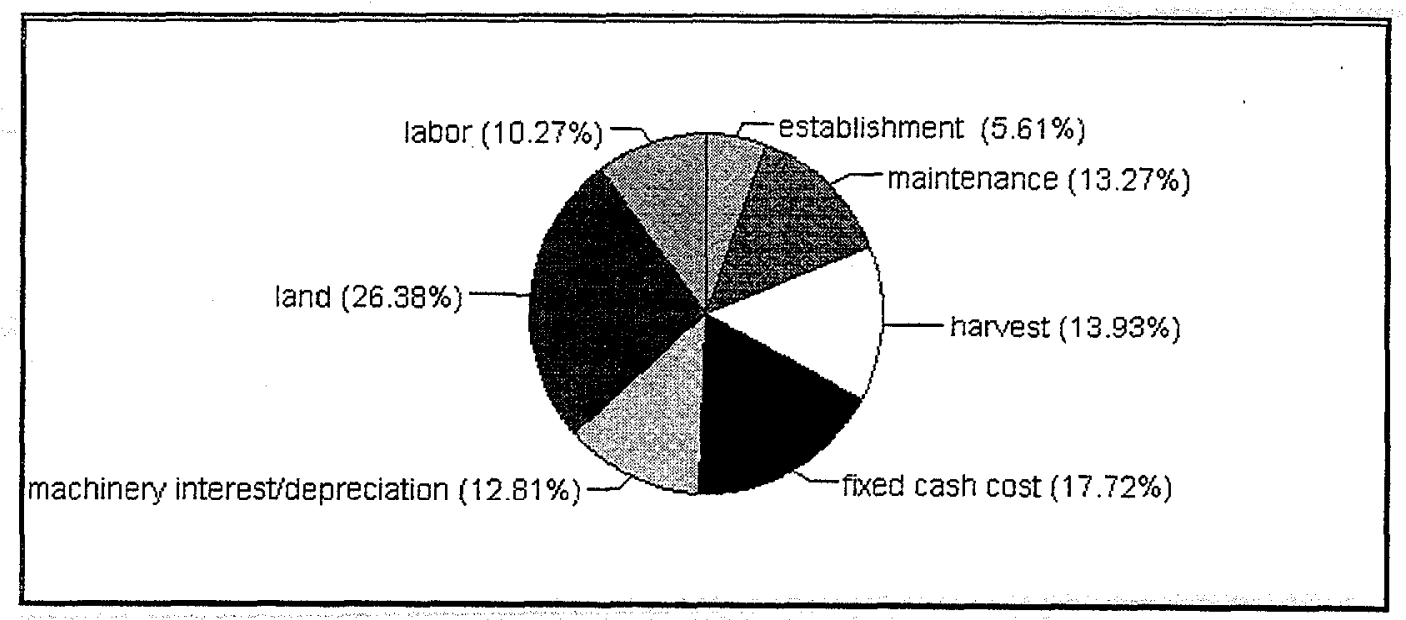

Fig. 10. Distribution of switchgrass costs by activity

\section{COSTS FOR BIOMASS WHEN BUFFER STRIPS ARE REQUIRED}

Consider the case where if chicken litter is to be applied to a field, a buffer strip is required and harvesting biomass to remove nutrients is not required (but harvesting is allowed). In the section of the buffer strip where harvesting is allowed, switchgrass which is the least costly to establish among willow, poplar, and switchgrass, is an acceptable choice of crop. In considering the decision as to what crop to plant and whether to harvest the biomass, the fixed cash costs of farm overhead, interest on real estate, and taxes and insurance; the economic (owned resource) costs of land (land rent) (excluding interest); and any costs associated with establishment of switchgrass [e.g., seed, lime, herbicides, soil testing, labor, nonland capital (interest on machinery), capital replacement (depreciation)]; are costs are that are incurred regardless of whether the biomass crop is harvested or not. These costs are incurred because a buffer strip is required if chicken litter is to be applied to the field. Therefore the costs associated with the decision to utilize the biomass crop for energy are for establishment costs above those of the least cost choice, switchgrass, and any yield enhancing activities such as fertilization, harvest costs, and transport costs. Under these circumstances, at a mature yield of $11.2 \mathrm{dry} \mathrm{Mg/ha-year} \mathrm{(5} \mathrm{dry} \mathrm{tons/acre-year),} \mathrm{delivered} \mathrm{costs} \mathrm{of} \mathrm{switchgrass}$ are $\$ 32 /$ dry $\mathrm{Mg}(\$ 1.85 / \mathrm{GJ})$ [ $\$ 29 /$ dry ton $(\$ 1.95 /$ million Btu)].

Consider the case where in addition to buffer strips being required, harvest is required to remove nutrients. In addition to the costs that are not allocated to the harvested biomass in the previous case, harvest costs are excluded from the biomass cost because harvest is required. At a mature yield of $11.2 \mathrm{dry} \mathrm{Mg} /$ ha-year (5 dry tons/acre-year) delivered costs of switchgrass are only $\$ 14 /$ dry $\mathrm{Mg}(\$ 0.80 / \mathrm{GJ})$ [ $\$ 13 /$ dry ton $(\$ 0.85 /$ million Btu)]. (These costs are for any applied fertilizer, which in the case of switchgrass is assumed to be nitrogen, and the cost of transporting the biomass from the field to the facility where it is used.)

For poplar at a yield of 11.2 dry $\mathrm{Mg} / \mathrm{ha}$-year ( 5 dry tons/acre-year), in the case where a buffer strip is required but harvesting is not required, delivered costs are $\$ 46 /$ dry $\mathrm{Mg}$ $(\$ 2.30 / \mathrm{GJ}$ [ $\$ 42 / \mathrm{dry}$ ton $(\$ 2.45 / \mathrm{million} \mathrm{Btu})]$ and in the case where harvesting is required delivered costs are $\$ 16 / \mathrm{dry} \mathrm{Mg}(\$ 0.80 / \mathrm{GJ})[\$ 15 / \mathrm{dry}$ ton $(\$ 0.85 /$ million Btu)]. These costs are calculated in comparison to what if the farmer had chosen the least cost switchgrass option. 
For willow with a 19-year stand life at a yield of 11.2 dry $\mathrm{Mg} /$ ha-year ( 5 dry tons/acreyear), in the case where a buffer strip is required but harvest is not required, delivered costs are $\$ 59 / \mathrm{dry} \mathrm{Mg}(\$ 3.00 / \mathrm{GJ})$ [ $\$ 54 /$ dry ton $(\$ 3.15 / \mathrm{million} \mathrm{Btu})]$ and in the case where harvest is required costs are $\$ 29 / \mathrm{dry} \mathrm{Mg}(\$ 1.50 / \mathrm{GJ})[\$ 27 / \mathrm{dry}$ ton $(\$ 1.55 / \mathrm{million} \mathrm{Btu})]$. These costs are calculated in comparison to what if the farmer had chosen the least cost switchgrass option.

These costs are compared to total costs in Fig. 11. Note that the reduction in cost between total costs and the costs for these two cases where buffer strips are required do not just disappear, but they are not borne by the biomass because regardless of whether the biomass is. used or not, the costs are incurred.

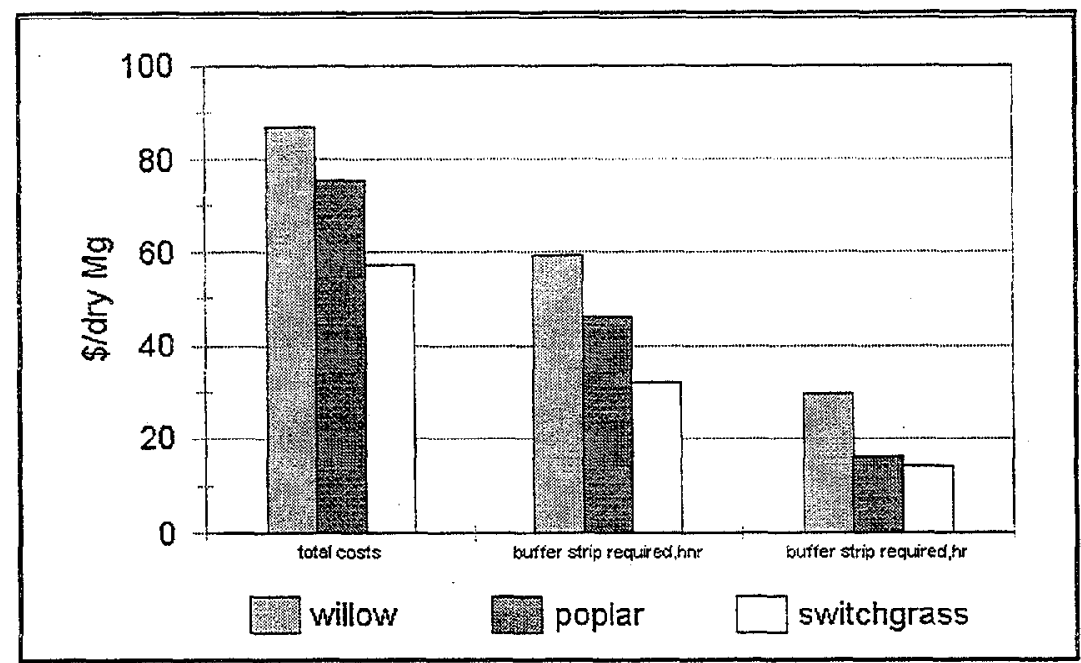

Fig. 11. Costs for delivered biomass (1999\$) when buffer strips are required [yield $=11.2 \mathrm{dry} \mathrm{Mg} / \mathrm{ha}$-year ( $5 \mathrm{dry}$ tons/ac-year)].

\section{ESTIMATES OF BIOMASS PRODUCED FROM BUFFER STRIPS}

To estimate how much biomass can be produced from buffer strips, one needs to know how much land will potentially be in buffer strips in the Delmarva Peninsula, what fraction of this land is harvested, and what is the yield of the harvested land. Assuming a buffer strip is on average $30 \mathrm{~m}\left(100^{\prime}\right)$ wide and the $4.6 \mathrm{~m}\left(15^{\prime}\right)$ closest to a water body is not harvested, then $85 \%$ of aggregate buffer strip area is harvested. Using baseline yield assumptions, yield averages about 11.2 dry $\mathrm{Mg} /$ ha ( 5 dry tons/acre-year).

The issue of how much land will potentially be in buffer strips is more complex. Poultry litter is not applied to all crops. However, because of crop rotations, it is assumed that poultry litter is applied to all cropland at some point in time and therefore all cropland may potentially need a buffer strip. Two methods are used to estimate buffer strip area.

The first method is based on data on stream length and riparian buffer width. Palone and Todd (1997) show data for riparian buffer width and stream length for watersheds in the Chesapeake Bay drainage in Maryland and Virginia, but not in Delaware. For Delaware and areas in Maryland and Virginia outside the Chesapeake Bay drainage, an extrapolation is made from the data for Maryland and Virginia in the Chesapeake Bay drainage, assuming the same length of streams per unit area both inside and outside of the Chesapeake Bay drainage. 
Poultry production and hence chicken litter field application is concentrated in the following counties: Kent and Sussex in Delaware; Caroline, Dorchester, Somerset, Talbot, Wicomico, and Worcester in Maryland; and Accomack in Virginia.

Riparian buffer width is classified in Palone and Todd as follows: both sides $91+\mathrm{m}$ $\left(300^{\prime}+\right)$, both sides $30-91 \mathrm{~m}\left(100-300^{\prime}\right)$, one side $91+\mathrm{m}\left(300^{\prime}+\right)$, one side $30-91 \mathrm{~m}\left(100-300^{\prime}\right)$, and both sides $<30 \mathrm{~m}\left(100^{\prime}\right)$. The data for one side $30-91 \mathrm{~m}\left(100-300^{\prime}\right)$ and both sides $<30 \mathrm{~m}$ $\left(100^{\prime}\right)$ add up to $100 \%$. One side $30-91 \mathrm{~m}\left(100-300^{\prime}\right)$ is interpreted to mean at least one side with a buffer $>30 \mathrm{~m}\left(100^{\prime}\right)$ in width and also both sides $30-91 \mathrm{~m}\left(100-300^{\prime}\right)$ to mean both sides have a buffer $>30 \mathrm{~m}\left(100^{\prime}\right)$ in width. If it is assumed that the concern is to establish buffers where present buffers are less than $30 \mathrm{~m}\left(100^{\prime}\right)$ in width, then the length of buffers needed along streams is two times both sides $<30 \mathrm{~m}\left(100^{\prime}\right)$ plus one side $30-91 \mathrm{~m}\left(100-300^{\prime}\right)$ minus both sides $30-91 \mathrm{~m}\left(100-300^{\prime}\right)$. This length is given in $\mathrm{km}$ (miles). Assuming a $30 \mathrm{~m}$ $\left(100^{\prime}\right)$ buffer is desired and ignoring any existing buffer less than $30 \mathrm{~m}\left(100^{\prime}\right)$ in width, then length in $\mathrm{km}$ (miles) can be converted buffer area in ha (acres) by multiplying by $1000 \mathrm{~m} / \mathrm{km}$ $\left(5280^{\prime} / \mathrm{mile}\right)$ and dividing by $10,000 \mathrm{~m}^{2} / \mathrm{ha}\left(43,560 \mathrm{ft}^{2} / \mathrm{acre}\right)$. Total buffer area needed to have a $30 \mathrm{~m} \mathrm{(100')} \mathrm{wide} \mathrm{buffer} \mathrm{on} \mathrm{all} \mathrm{streams} \mathrm{is} 43,000$ ha (106,000 acres) in the parts of Maryland and Virginia in the Chesapeake Bay drainage (Table 13). (Table 13 in its equivalent English units is Table A.3 in Appendix A.)

The 1992 National Resources Inventory (NRI), available from the NRCS of the U.S. Department of Agriculture, is used to determine which fractions of Worcester County in Maryland and Accomack County in Virginia are in the Chesapeake Bay drainage. All other counties of interest in Maryland lie completely within the Chesapeake Bay drainage. In Table 14 , the estimation of needed buffer area is shown. Areas for which data are available for riparian buffer size and stream length are indicated as "data available." Areas for which data are not available, both within the Chesapeake Bay drainage (parts of Kent and Sussex counties in Delaware) and areas outside the Chesapeake Bay drainage (parts of Kent and Sussex counties in Delaware, Worcester County in Maryland, and Accomack County in Virginia) are indicated as "no data available." There are 42,900 ha (106,000 acres) needed in buffers in the $5993 \mathrm{~km}^{2}\left(2314 \mathrm{mi}^{2}\right)$ with data. Assuming the same density of buffers is needed in the $5346 \mathrm{~km}^{2}\left(2064 \mathrm{mi}^{2}\right)$ without data, then $81,500 \mathrm{ha}(201,000$ acres $)$ are required in the. whole area (Table 14).

This is an overestimate because not all stream lengths are affected by poultry litter runoff, and some area of buffers exist, although less than $30 \mathrm{~m}\left(100^{\prime}\right)$ in width. According to the 1992 Census of Agriculture (USDOC 1993-1994) 400,000 ha (987,000 acres) are in cropland, which is $35.2 \%$ of total land area. Taking $35.2 \%$ of 81,400 ha (201,000 acres) in the total area results in 28,700 ha (70,900 acres) of buffer required in farming areas.

The second method involves some assumptions about field geometry and buffer strip returned. For a square $40(10)$ ha $\left[100(25)\right.$ ac] field with a $30-\mathrm{m}\left(100^{\prime}\right)$ buffer strip on one side, the buffer strip occupies approximately $5 \%(10 \%)$ of the field. If every field requires a buffer strip on one side, then between $5 \%$ and $10 \%$ of cropland would be in buffer strips. Thus between 20,000 and 40,000 ha $(49,400$ and 98,700 acres) would need to be in buffer strips. 
Table 13. Length of streams and buffer width by watershed in the Delmarva Peninsula in the Chesapeake Bay drainage

\begin{tabular}{|c|c|c|c|c|c|c|c|}
\hline \multirow[b]{2}{*}{ Watershed } & \multirow[b]{2}{*}{$\begin{array}{l}\text { Stream } \\
\text { length }\end{array}$} & \multicolumn{5}{|c|}{ Length of stream with buffers of stated widths } & \multirow[b]{2}{*}{$\begin{array}{c}\text { Buffer } \\
\text { area } \\
\text { needed }\end{array}$} \\
\hline & & $\begin{array}{c}\text { Both sides } \\
30.5-91.5 \\
\mathrm{~m}\end{array}$ & $\begin{array}{c}1 \text { side } \\
30.5-91.5 \\
\mathrm{~m}\end{array}$ & $\begin{array}{c}\text { Both sides } \\
<30.5 \mathrm{~m} \\
\end{array}$ & $\begin{array}{l}1 \text { side }< \\
30.5 \mathrm{~m} \\
\end{array}$ & $\begin{array}{c}\text { Total } \\
\text { length }< \\
30.5 \mathrm{~m} \\
\end{array}$ & \\
\hline Maryland & \multicolumn{6}{|c|}{$\mathrm{km}$} & ha \\
\hline Pocomoke Sound & 242.7 & 48.6 & 60.8 & 181.9 & 12.2 & 375.9 & 1146 \\
\hline Lower Pokomoke River & 324.8 & 203.1 & 223.2 & 101.5 & 20.1 & 223.2 & 681 \\
\hline Upper Pokomoke River & 202.5 & 117.2 & 121.5 & 81.0 & 4.3 & 166.2 & 507 \\
\hline Dividing Creek & 92.4 & 80.3 . & 82.6 & 9.8 & 2.3 & 21.9 & 67 \\
\hline Nassawango Creek & 96.9 & 71.5 & 74.4 & 22.5 & 2.9 & 48.0 & 146 \\
\hline Tangier Sound & 346.2 & 4.5 & 6.8 & 339.4 & 2.3 & 681.1 & 2077 \\
\hline Big Annemessex River & 186.2 & 28.0 & 35.9 & 150.3 & 7.9 & 308.5 & 941 \\
\hline Manokin River & 328.9 & 80.5 & 95.1 & 233.8 & 14.6 & 482.3 & 1471 \\
\hline Lower Wicomico River & 333.0 & 77.1 & 89.6 & 243.3 & 12.6 & 499.2 & 1522 \\
\hline Monie Bay & 117.8 & 9.7 & 10.9 & 106.9 & 1.3 & 215.0 & 656 \\
\hline Wicomico Creek & 71.5 & 23.0 & 26.9 & 44.6 & 3.9 & 93.0 & 284 \\
\hline Wicomico River Head & 100.7 & 51.8 & 58.1 & 42.6 & 6.3 & 91.6 & 279 \\
\hline Nanticoke River & 650.8 & 162.5 & 188.9 & 461.9 & 26.4 & 950.2 & 2897 \\
\hline Maryshope Creek & 469.4 & 219,4 & 249.1 & 220.3 & 29.8 & 470.4 & 1434 \\
\hline Fishing Bay & 803.2 & 46.0 & 59.7 & 743.5 & 13.7 & 1500.7 & 4576 \\
\hline Transquaking River & 396.9 & 94.5 & 117.2 & 279.7 & 22.7 & 582.1 & 1775 \\
\hline Honga River & 341.5 & 14.2 & 18.2 & 323.3 & 4.0 & 650.7 & 1984 \\
\hline Little Choptank & 358.4 & 17.7 & 23.5 & 334.9 & 5.8 & 675.6 & 2060 \\
\hline Lower Choptank & 970.4 & 126.0 & 164.0 & 806.4 & 38.0 & 1650.9 & 5034 \\
\hline Upper Choptank & 868.6 & 395.6 & 448.5 & 420.0 & 52.9 & 893.0 & 2723 \\
\hline Tackahoe creek & 566.7 & 200.5 & 237.4 & 329.3 & 36.9 & 695.4 & 2120 \\
\hline Eastern Bay & 168.7 & 6.3 & 9.3 & 159.3 & 3.1 & 321.7 & 981 \\
\hline Miles River & 215.0 & 29.5 & 38.1 & 176.9 & 8.7 & 362.4 & 1105 \\
\hline Wye River & 282.0 & 71.9 & 88.8 & 193.1 & 16.9 & 403.1 & 1229 \\
\hline Total Maryland & & & & & & 12362.2 & 37696 \\
\hline Virginia & & & & & & & \\
\hline Pokomoke River/Pitts Creek & 72.3 & 32.0 & 37.2 & 35.1 & 5.1 & 75.3 & 230 \\
\hline $\begin{array}{l}\text { Chesapeake Bay/Holdens } \\
\text { Creek }\end{array}$ & 672.9 & 78.4 & 93.2 & 579.7 & 14.8 & 1174.2 & 3580 \\
\hline $\begin{array}{l}\text { Chesapeake Bay/Onancock } \\
\text { Creek }\end{array}$ & 217.7 & 10.1 & 13.5 & 204.2 & 3.4 & 411.8 & 1256 \\
\hline Pungoteague Creek & 63.1 & 13.0 & 15.0 & 48.1 & 1.9 & 98.2 & 299 \\
\hline Total Virginia & & & & & & 1759.5 & 5365 \\
\hline Total & & & & & & 14121.7 & 43061 \\
\hline
\end{tabular}


Table 14. Area with stream length and buffer width data and buffer area needed

\begin{tabular}{|c|c|c|c|c|c|c|c|c|c|c|}
\hline \multirow[b]{2}{*}{ County, state } & $\begin{array}{c}\text { Data } \\
\text { available }\end{array}$ & $\begin{array}{c}\text { No data } \\
\text { available }\end{array}$ & \multicolumn{2}{|c|}{ Land area } & \multicolumn{2}{|c|}{ Data available } & \multicolumn{2}{|c|}{$\begin{array}{l}\text { No data } \\
\text { available }\end{array}$} & \multicolumn{2}{|c|}{$\begin{array}{c}\text { Buffer area } \\
\text { needed }\end{array}$} \\
\hline & Fract & & $\mathrm{km}^{2}$ & $m i^{2}$ & $\mathrm{~km}^{2}$ & $\mathrm{mi}^{2}$ & $\mathrm{~km}^{2}$ & $\mathrm{mi}^{2}$ & ha & Acres \\
\hline Kent, DE & 0.000 & 1.000 & 1541 & 595 & 0 & 0 & 1541 & 595 & & \\
\hline Sussex, DE & 0.000 & 1.000 & 2440 & 942 & 0 & 0 & 2440 & 942 & & \\
\hline Caroline, MD & 1 & 0 & 831 & 321 & 831 & 321 & 0 & 0 & & \\
\hline Dorchester, MD & 1 & 0 & 1536 & 593 & 1536 & 593 & 0 & 0 & & \\
\hline Somerset, MD & 1 & 0 & 875 & 338 & 875 & 338 & 0 & 0 & & \\
\hline Talbot, MD & 1 & 0 & 671 & 259 & 671 & 259 & 0 & 0 & & \\
\hline Wicomico, MD & 1 & 0 & 982 & 379 & 982 & 379 & 0 & 0 & & \\
\hline Worcester, MD & 0.480 & 0.520 & 1230 & 475 & 590 & 228 & 640 & 247 & & \\
\hline Accomack, VA & 0.412 & 0.588 & 1233 & 476 & 508 & 196 & 725 & 280 & & \\
\hline Total & & & & & 5993 & 2314 & 5346 & 2064 & 81480 & 201250 \\
\hline
\end{tabular}

\section{SUMMARY AND CONCLUSIONS}

Total (economic) costs of delivered biomass ( $\$ 1999)$, at 11.2 dry $\mathrm{Mg}$ /ha-year (5 dry tons/acre-year), of willow are $\$ 84$ to $\$ 108 / \mathrm{dry} \mathrm{Mg}$ ( $\$ 76$ to $\$ 98 / \mathrm{dry}$ ton) [ $\$ 4.25$ to $\$ 5.45 / \mathrm{GJ}$ (\$4.50 to $\$ 5.75 /$ million Btu)], poplar are $\$ 76 / \mathrm{dry} \mathrm{Mg}$ (\$69/dry ton) [ $\$ 3.80 / \mathrm{GJ}$ (\$4.05/million Btu)], and switchgrass are $\$ 57 /$ dry $\mathrm{Mg}(\$ 52 /$ dry ton) [ $\$ 3.30 / \mathrm{GJ}$ ( $\$ 3.45 / \mathrm{million}$ Btu)]. With CRP payments, delivered costs decrease significantly to $\$ 40$ to $\$ 75 / \mathrm{dry} \mathrm{Mg}$ ( $\$ 37$ to $\$ 68 / \mathrm{dry}$ ton) $[\$ 2.30$ to $\$ 3.80 / \mathrm{GJ}$ ( $\$ 2.45$ to $\$ 4.00 /$ million Btu)] and with enhanced CRP payments, delivered costs are $\$ 30$ to $\$ 49 / \mathrm{dry} \mathrm{Mg}$ ( $\$ 27$ to $\$ 44 / \mathrm{dry}$ ton) $[\$ 1.70$ to $\$ 2.45 / \mathrm{GJ}$ ( $\$ 1.80$ to $\$ 2.60 /$ million Btu)] (Fig. 12). Willow costs are significantly higher than switchgrass costs because establishment costs are nine times greater, and harvest costs are about $\$ 6 / \mathrm{dry} \mathrm{Mg}$ (\$5/dry ton) higher.

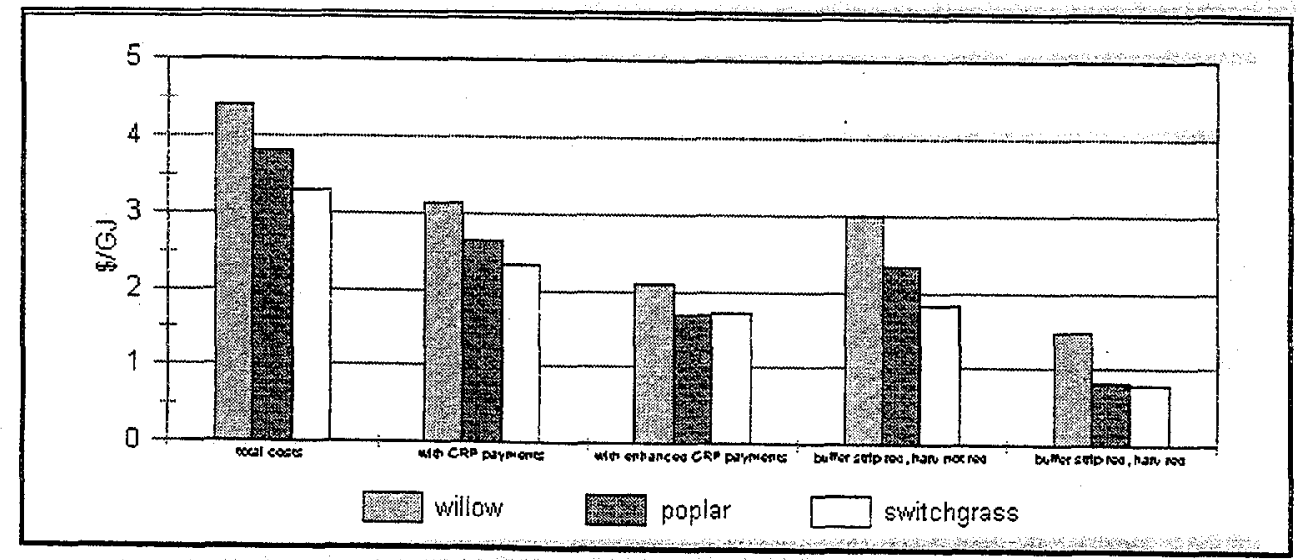

Fig. 12. Costs of willow, poplar, and switchgrass at $11.2 \mathrm{dry} \mathrm{Mg/ha-year}$ ( 5 dry tons/ac-year). 
If buffer strips are required to prevent nutrient runoff into water bodies, but harvesting is not required to remove nutrients from the buffer strips, delivered biomass costs are significantly less than total costs. Delivered costs range from $\$ 32$ to $\$ 76 / \mathrm{dry} \mathrm{Mg}$ ( $\$ 29$ to $\$ 68 /$ dry ton) [ $\$ 1.85$ to $\$ 3.80 / \mathrm{GJ}$ ( $\$ 1.95$ to $\$ 4.05 /$ million Btu)], similar to costs with CRP payments. These costs are primarily for establishment costs above those of establishing the least cost buffer with switchgrass, some fertilizers assumed required for optimal yields, harvest, and transportation. If in addition harvest is required to remove nutrients, then delivered biomass costs are low and range from $\$ 14$ to $\$ 43 /$ dry $M g$ ( $\$ 13$ to $\$ 39 /$ dry ton) [ $\$ 0.80$ to $\$ 2.20 / \mathrm{GJ}(\$ 0.85$ to $\$ 2.30 /$ million Btu)]. These costs are primarily for establishment costs above those of establishing the least cost buffer with switchgrass, some fertilizers assumed required for optimal yields, and transportation. The higher end of these ranges is for willow with shorter stand lives. Costs are low because significant costs are required to be borne by the chicken litter disposal activity regardless of whether the biomass is harvested and delivered.

One of the concerns with regards to costs is that of small tract size being planted and harvested. The costs reported assume no additional costs because of small tract size. For willow, a 0.8 -ha (2-acre) tract increases total costs by $\$ 3.30 / \mathrm{dry} \mathrm{Mg}(\$ 3.00 / \mathrm{dry}$ ton) and a 2-ha (5-acre) tract by $\$ 1.20 /$ dry $\mathrm{Mg}(\$ 1.10 /$ dry ton). For poplar, a 0.8 -ha (2-acre) tract increases costs by $\$ 2.00 /$ dry $\mathrm{Mg}(\$ 1.80 /$ dry ton) and a 2 -ha (5-acre) tract by $\$ 0.65 / \mathrm{dry} \mathrm{Mg}$ $(\$ 0.60 /$ dry ton). For switchgrass, a 0.8 -ha (2-acre) tract increases costs by $\$ 2.20 / \mathrm{dry} \mathrm{Mg}$ ( $\$ 2.00 /$ dry ton) and a 2 -ha (5-acre) tract by $\$ 0.65 /$ dry $\mathrm{Mg}(\$ 0.60 /$ dry ton).

There are a number of means to reduce costs. For any of the three crops, one method is to increase average annual yield. An increase in average annual yield from 11.2 to $13.4 \mathrm{dry}$ $\mathrm{Mg} /$ ha-year ( 5 to 6 dry tons/acre-year) decreases costs by $10 \%$ to $13 \%$. At higher yields, fixed costs (e.g., establishment, land) are spread over more units of production and harvest equipment is more productive. Another possibility is to decrease the average transportation distance through the locations of buffer strips and conversion facilities. For example, for switchgrass each truck is assumed to make three trips per eight hour day. With four trips per eight hour day, costs are reduced $\$ 1.65 / \mathrm{dry} \mathrm{Mg}\left(\$ 1.50 /\right.$ dry ton) for $1.83 \mathrm{~m}\left(6^{\prime}\right)$ diameter bales and $\$ 2.10 /$ dry $\mathrm{Mg}\left(\$ 1.90 / \mathrm{dry}\right.$ ton) for $1.52 \mathrm{~m}\left(5^{\prime}\right)$ diameter bales. For willow and poplar, if trips increase by $33 \%$ per day, as in the switchgrass example [each trip takes 1.35 hours and distance is $60 \mathrm{~km}(37.5 \mathrm{miles})]$, then costs decrease by $\$ 2.85 / \mathrm{dry} \mathrm{Mg}(\$ 2.60 / \mathrm{dry}$ ton). The reduced transportation costs for switchgrass are approximately $\$ 0.30 / \mathrm{GJ}$ ( $\$ 0.30$ million Btu) and for willow and poplar are approximately $\$ 0.45 / \mathrm{GJ}(\$) .50 / \mathrm{GJ})$.

It may be possible to reduce willow harvest costs by using smaller scale equipment. Establishment costs may be reduced though the propagation of lower cost cuttings. Also the possibility of using wider spacings should be investigated as a means to reduce establishment costs. For willow, where establishment costs are $30 \%$ to $40 \%$ of total costs, reducing either the cost of cuttings or density of trees can have an impact. If cuttings cost $\$ 0.07$ instead of $\$ 0.10$, then total costs for a $19-y e a r$ stand life are reduced by $\$ 5 /$ dry $\mathrm{Mg}(\$ 4 / \mathrm{dry}$ ton). If stand density is reduced to 12,350 trees/ha (5000 trees/acre) from 15,300 trees/ha (6200 trees/acre), then for a 19 -year stand life costs are reduced by $\$ 4 / \mathrm{dry} \mathrm{Mg}(\$ 4 / \mathrm{dry}$ ton). Combining the lower cost per cutting plus lower density reduces costs by $\$ 8 / \mathrm{dry} \mathrm{Mg}(\$ 7 / \mathrm{dry}$ ton), and delivered costs to $\$ 79 / \mathrm{dry} \mathrm{Mg}(\$ 71 /$ dry ton). Harvest uses an expensive machine, the Claas Jaguar harvester. If similar productivity can be achieved using a less expensive tractormounted harvest head, then it may be possible to reduce harvest costs by $\$ 6$ to $\$ 11 /$ dry $\mathrm{Mg}$ ( $\$ 5$ to $\$ 10 /$ dry ton). With a tractor-mounted harvest head with a one man harvest crew which results in a $\$ 6 / \mathrm{dry} \mathrm{Mg}(\$ 5 / \mathrm{dry}$ ton) reduction in harvest cost, a round trip transport distance of 
$60 \mathrm{~km}$ (37.5 miles) and time of 1.35 hours, cuttings at $\$ 0.07$ each, 12,350 cuttings $/$ ha $(5000$ cuttings/acre), and a yield of $18 \mathrm{dry} \mathrm{Mg} /$ ha-year ( 8 dry tons/acre-year), then total delivered costs decrease to $\$ 49 / \mathrm{dry} \mathrm{Mg}(\$ 44 / \mathrm{dry}$ ton) [ $\$ 2.45 / \mathrm{GJ}(\$ 2.60 /$ million Btu)]. This is probably as low a total economic cost (without any payments such as from the CRP) as biomass can be produced from willow.

For poplar, a yield of 13.4 dry $\mathrm{Mg} /$ ha-year ( 6 dry tons/acre-year) reduces total costs to $\$ 67 /$ dry Mg (\$61/dry ton) [ $\$ 3.40 /$ GJ $(\$ 3.60 /$ million Btu)]. Reducing the cost of cuttings plus planting from $\$ 0.24 /$ cutting to $\$ 0.15 /$ cutting reduces costs by $\$ 2 /$ dry $\mathrm{Mg}$ ( $\$ 2 /$ dry ton). With the use of more appropriately sized harvest equipment which results in a $\$ 6 / \mathrm{dry} \mathrm{Mg}(\$ 5 / \mathrm{dry}$ ton) reduction in harvest cost, a round trip transport distance of $60 \mathrm{~km}$ ( 37.5 miles) and time of 1.35 hours, cuttings at $\$ 0.10$ each, planting costs of $\$ 0.05 /$ cutting, and a yield of 17.9 dry $\mathrm{Mg} /$ ha-year ( 8 dry tons/acre-year), then total delivered costs decrease to $\$ 47 / \mathrm{dry} \mathrm{Mg}(\$ 42 / \mathrm{dry}$ ton) $[\$ 2.35 / \mathrm{GJ}(\$ 2.50 /$ million Btu $)]$.

For switchgrass, because hay production systems are much more mature, possible decreases in cost are much less than for willow. Costs can be reduced by producing $1.52 \mathrm{~m}$ $\left(5^{\prime}\right)$ wide bales instead of $1.22 \mathrm{~m}$ (4') wide bales. For a yield of $15.7 \mathrm{dry} \mathrm{Mg} / \mathrm{ha}$-year ( $7 \mathrm{dry}$ tons/acre-year) and transportation costs based on four round trips per eight hour day, total delivered costs are $\$ 46 /$ dry $\mathrm{Mg}(\$ 41 /$ dry ton) $[\$ 2.60 / \mathrm{GJ}$ ( $\$ 2.75 /$ million Btu)].

With the most optimistic possible improvements in SRWC and switchgrass growing, harvest, and transport conditions, one can envision total delivered costs as low as $\$ 46$ to $\$ 49 /$ dry Mg ( $\$ 41$ to $\$ 44 /$ dry ton) [ $\$ 2.35$ to $\$ 2.60 / \mathrm{GJ}(\$ 2.50$ to $\$ 2.75 / \mathrm{million}$ Btu)] and with enhanced CRP payments as low as $\$ 22$ to $\$ 28 /$ dry $\mathrm{Mg}$ ( $\$ 20$ to $\$ 25 /$ dry ton) [ $\$ 1.15$ to $\$ 1.60 / \mathrm{GJ}$ ( $\$ 1.20$ to $\$ 1.70 /$ million Btu)].

High yields are required for low total costs, but yields do not greatly affect the producer cost of biomass when enhanced CRP payments are received. The lowest CRP payments per unit of biomass produced is for switchgrass. However switchgrass may not produce the same environmental benefits as with SRWC, because of differences in rooting depths and their possible impacts on treating groundwater contaminants, abilities to cause sediment deposition from surface water runoff, and wildlife habitat impacts.

If buffer strips are a required practice, then biomass costs are significantly lower than total costs, with costs ranging from $\$ 32$ to $\$ 76 / \mathrm{dry} \mathrm{Mg}$ ( $\$ 29$ to $\$ 68 / \mathrm{dry}$ ton) [ $\$ 1.85$ to $\$ 3.80 / \mathrm{GJ}(\$ 1.95$ to $\$ 4.05 / \mathrm{million} \mathrm{Btu})]$ if no harvest is required and $\$ 14$ to $\$ 43 / \mathrm{dry} \mathrm{Mg}(\$ 13$ to $\$ 39 /$ dry ton) [ $\$ 0.80$ to $\$ 2.20 / \mathrm{GJ}$ ( $\$ 0.85$ to $\$ 2.30 /$ million Btu)] if harvest is required to remove nutrients. The cost differentials from total economic costs do not just disappear, but these costs are not borne by the harvested biomass. The cost differentials are borne by activities that contribute to nutrient runoff into the waterways of the Delmarva Peninsula.

The potential production of biomass from riparian buffer strips in the Delmarva Peninsula ranges from 190,000 to $380,000 \mathrm{Mg}(210,000$ to 420,000 dry tons) per year. 


\section{REFERENCES}

Antares Group Inc., T.R. Miles Technical Consulting, Inc., and Foster Wheeler Development Corp. 1999. Economic and technical feasibility of energy production from poultry litter and nutrient filter biomass on the lower Delmarva Peninsula. Northeast Regional Biomass Program, Washington, D.C.

Bureau of Labor Statistics. 1998. 1998-1999 Occupational Outlook Handbook. http://stats.bls.gov/oco/ocos246.htm\#earnings. U.S. Department of Labor, Washington, D.C.

Culshaw, D. and B. Stokes. 1995. "Mechanisation of short rotation forestry," Biomass and Bioenergy 9(1-5):127-140.

Esseks, J. D. and S. E. Kraft. 1986. "Landowner views of obstacles to wider participation in the conservation reserve program," Journal of Soil and Water Conservation 41(November-December). pp. 410-414.

Esseks, J. D. and S. E. Kraft. 1988. "Why eligible landowners did not participate in the first four sign-ups of the Conservation Reserve Program," Journal of Soil and Water Conservation 43(May-June). pp. 251-256.

Esseks, J. D. and S. E. Kraft. 1989. "Marketing the Conservation Reserve Program," Journal of Soil and Water Conservation 44(September-October). pp. 425-430.

Feather, P, D. Hellerstein, and L. Hansen. 1998. "Exploring methods of selecting cropland for conservation" Agricultural Outlook September pp. 21-24. U.S. Department of Agriculture, Economic Research Service, Washington, D.C.

FHWA (Federal Highway Administration). 1993. Highway taxes and fees: how they are collected and distributed. FHWA-PL-93-018. Federal Highway Administration, U.S. Department of Transportation, Washington, D.C.

FHWA (Federal Highway Administration). 1998a. g/fs, Table MF-121T. http://www.fhwa.dot.gov. Federal Highway Administration, U.S. Department of Transportation, Washington, D.C.

FHWA (Federal Highway Administration). 1998b. Federal highway-user fees, Table FE21B. http://www.fhwa.dot.gov. Federal Highway Administration, U.S. Department of Transportation, Washington, D.C.

Force, D. and N. Bills. 1989. "Participation in the CRP: implications of the New York experience," Journal of Soil and Water Conservation 44(September-October). pp. 512-516.

Hatley, M. L., R. T. Ervin, and B. Davis. 1989. "Socioeconomic characteristics of participants in the CRP: Texas High Plains," Journal of Soil and Water Conservation 44(September-October) pp. 510-512.

Hartsough, B. and D. Yomogida. 1996. Compilation of state-of-the-art mechanization technologies for short-rotation woody crop production. University of California, Davis.

Hunt, D. 1995. Farm power and machinery management, $9^{\text {th }}$ ed. Iowa State University Press, Ames, IA.

Johnson, D. M. and M. B. West. c. 1994. Custom-work charges and land-rental rates in Maryland. Fact sheet 683. Cooperative Extension Service, University of Maryland at College Park and University of Maryland Eastern Shore. 
Johnson, L. R. and R. Folk. 1995. Wood residue recovery costs, report submitted to Biofuels Feedstock Development Program, Oak Ridge National Laboratory. Forest Products Department, University of Idaho, Moscow, Idaho.

Jones, J. 1997. Cash rents for U.S. farmland [computer file]. \#90025. U.S. Department of Agriculture, Economic Research Service, Washington, D.C.

Kofman, P. D. and R. Spinelli. 1997. An evaluation of harvesting machinery for short rotation coppice willow in Denmark. Forskningscentret for Skov \& Landskab, Horsholm, Denmark.

Kopp, R. F., L. P. Abrahamson, E. H. White, T. A. Volk, and J. M. Peterson. 1997. Willow Biomass Producer's Handbook. National Technical Information Service, Springfield, VA.

Lant, C. L., S. E. Kraft, and K. R. Gillman. 1995. "Enrollment of filter strips and recharge areas in the CRP and USDA easement programs," Journal of Soil and Water Conservation 50(1):193-200.

Maryland Department of Agriculture. c. 1998. Enhanced cost-share \$\$ for streamside conservation, Maryland's Conservation Reserve Enhancement Program. Annapolis, MD.

Mitchell, C.P. 1997. Development of harvesting and storage technologies essential for the establishment of short rotation forestry as an economic source of fuel in Europe. AAIR3 CT94 1102, Final technical report. Aberdeen University, Department of Forestry, Aberdeen, U.K.

Mixon, J. and L. Thompson. 1989. "Forestation and the CRP," Journal of Soil and Water Conservation 44(September-October). pp. 437.

Morse, D. 1987. "Trees to grow under CRP," Soil and Water Conservation News 8(8):4-5.

Mortensen, T. L., F. L. Leistritz, J. A. Leitch, R. C. Coon, and B. L. Ekstrom. 1989. "Landowner characteristics and the economic impact of the Conservation Reserve Program in North Dakota," Journal of Soil and Water Conservation 44(September-October). pp. 494-495.

Noon, C. 1996. Unpublished data. Department of Management Resources, University of Tennessee, Knoxville.

Olmstead, C. J. and D. R. McCurdy. 1989. "Factors affecting tree planting by landowners under the CRP, southern Illinois, 1986-87," Journal of Soil and Water Conservation 44(September-October). pp. 498-500.

Osborn, T. 1997. "New CRP criteria enhance environmental gains," Agricultural Outlook October:15-18. U.S. Department of Agriculture, Economic Research Service, Washington, D.C.

Palone, R.S. and A.H. Todd (eds.). 1997. Chesapeake Bay riparian handbook: a guide for establishing and maintaining riparian forest buffers. USDA Forest Service. NA-TP-0297. Radnor, PA.

Purvis, A., J. P. Hoehn, V.L. Sorenson, and F. J. Pierce. 1989. "Farmers' response to a filter strip program: results from a contingent valuation survey," Journal of Soil and Water Conservation 44(September-October). pp. 501-504.

Smith, M. 1999. "Conservation reserve program approaches acreage limit," Agricultural Outlook June/July:23-26. U.S. Department of Agriculture, Economic Research Service, Washington, D.C.

Turhollow, A. F., M. E. Downing, and J. L. Butler. 1998. Forage harvest and transport costs. ORNL/TM-13724 Oak Ridge National Laboratory, Oak Ridge, TN. 
USDA/ERS (U.S. Department of Agriculture/Economic Research Service). 1997. Agricultural resources and environmental indicators, 1996-97. Agriculture Handbook No. 712. U.S. Department of Agriculture, Economic Research Service, Washington, D.C. USDA/NASS (U.S. Department of Agriculture/National Agricultural Statistics Service). 1996. Agricultural prices - 1995 summary. Pr 1-3 (96). U.S. Department of Agriculture, National Agricultural Statistics Service, Washington, D.C.

USDA/NASS (U.S. Department of Agriculture/National Agricultural Statistics Service). 1998a. Agricultural cash rents. U.S. Department of Agriculture, National Agricultural Statistics Service, Washington, D.C.

USDA/NASS (U.S. Department of Agriculture/National Agricultural Statistics Service). 1998b. Crop production 1997 summary. Cr PR 2-1(98). U.S. Department of Agriculture, National Agricultural Statistics Service, Washington, D.C.

USDA/NRCS (U.S. Department of Agriculture/Natural Resources Conservation Service). 1997a. Filter strip (acre), Code 393A. Conservation practice standard. U.S. Department of Agriculture, Natural Resources Conservation Service.

USDA/NRCS (U.S. Department of Agriculture/Natural Resources Conservation Service). 1997b. Riparian forest buffer (Acre), Code 391A. Conservation practice standard. U.S. Department of Agriculture, Natural Resources Conservation Service.

USDA/SCS (U.S. Department of Agriculture/Soil Conservation Service), Delaware. 1984. Standards and specifications for filter strips (ac), Code 393. Technical guide, section IV. U.S. Department of Agriculture, Soil Conservation Service, Delaware.

USDOC/BEA (U.S. Department of Commerce/Bureau of Economic Affairs). 1998. Survey of current business. 78(11). U.S. Department of Commerce, Bureau of Economic Affairs, Washington, D.C.

USDOC/BOC (U.S. Department of Commerce/Bureau of Census). 1993-94. 1992 Census of Agriculture, Vol. 1, Geographic area series. U.S. Department of Commerce, Bureau of the Census, Washington, DC.

Walsh, M. E. and D. A. Becker. 1996. BIOCOST documentation. Biofuels Feedstock Development Program, Oak Ridge National Laboratory, Oak Ridge, Tenn.

West, A. J. 1988. "Conservation reserve tree planting: can we improve upon success?" Journal of Soil and Water Conservation 43(January-February). pp. 66-67. 

APPENDIX A

TABLES 1, 7, AND 13 IN ENGLISH UNITS 
1 
Table A1. Boilers and cropland in the Delmarva Peninsula

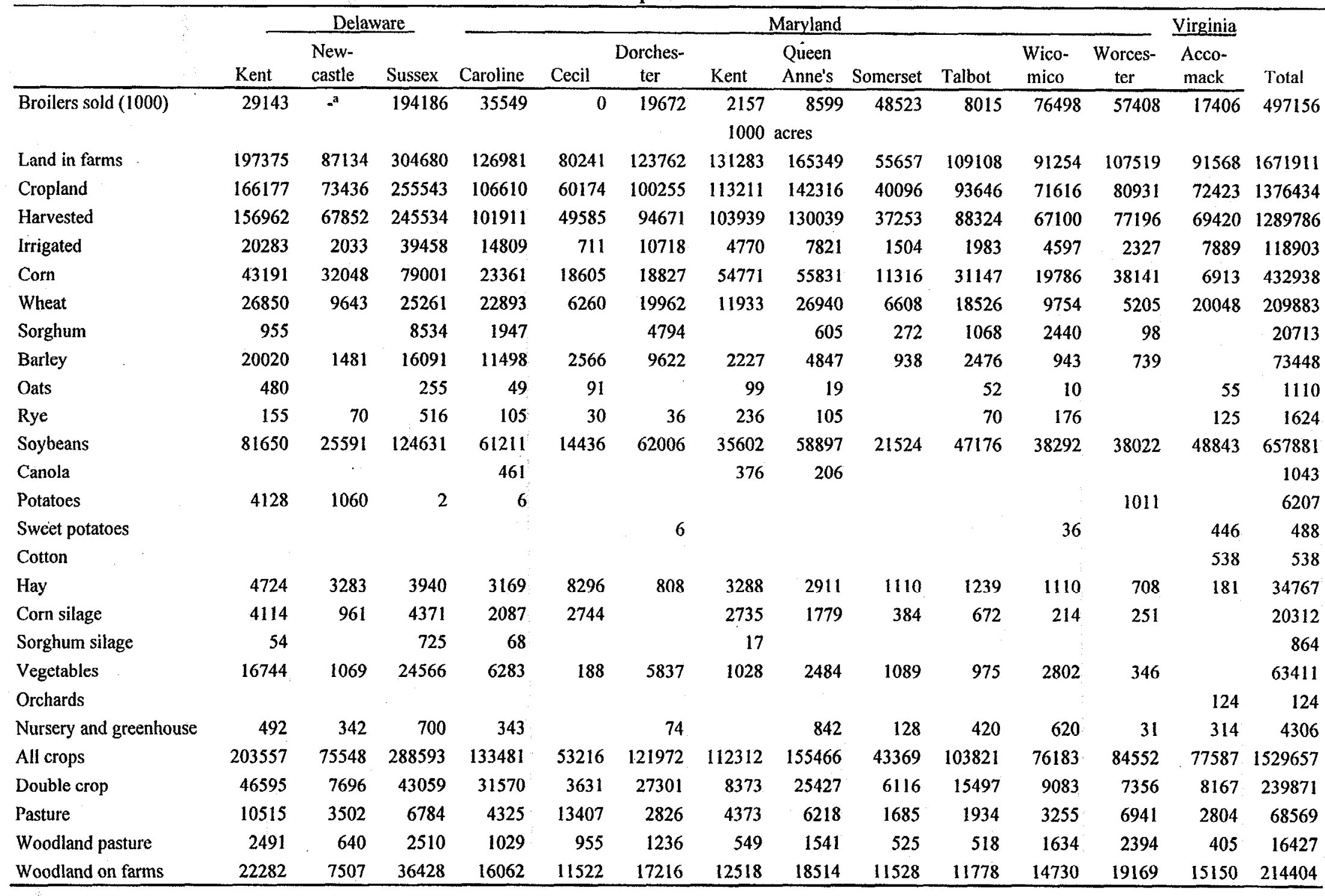

${ }^{2}$ Broiler data in Delaware for Kent and New Castle counties are not disaggregated, but most broilers are likely in Kent County Source: USDOC/BOC (1993-1994) 
Table A2. Machinery prices and parameters (costs in 1995\$)

\begin{tabular}{|c|c|c|c|c|c|c|c|c|c|c|c|}
\hline Machine type & $\begin{array}{c}\text { Purchase } \\
\text { price }\end{array}$ & Lifetime (hrs) & $\begin{array}{c}\text { Annual use } \\
\text { (hrs) }\end{array}$ & Repair rates & $\begin{array}{l}\text { Speed } \\
(\mathrm{mph})\end{array}$ & Width (ft) & $\begin{array}{c}\text { Field } \\
\text { efficiency }\end{array}$ & $\begin{array}{c}\text { Hours/ } \\
\Lambda \text { cre }\end{array}$ & $\begin{array}{c}\begin{array}{c}\text { Lifetime } \\
\text { (yrs) }\end{array} \\
\end{array}$ & $\begin{array}{c}\text { Fuel use } \\
\text { (gal/hr) }\end{array}$ & $\begin{array}{l}\text { Oil use } \\
\text { (gal/hr) }\end{array}$ \\
\hline Moldboard plow, 6-16" & 10700 & 2000 & 200 & 100 & 4.50 & 8.00 & 0.85 & 0.27 & 10.0 & & \\
\hline Moldboard plow, 7-16" & 13800 & 2000 & 200 & 100 & 4.50 & 9.33 & 0.85 & 0.23 & 10.0 & & \\
\hline Chisel plow, $15^{\prime}$ & 6321 & 2000 & 200 & 75 & 5.00 & 15.00 & 0.85 & 0.13 & 10.0 & & \\
\hline Offset disk, $14 \mathrm{ft}$. & 8200 & 2000 & 200 & 60 & 6.00 & 14.00 & 0.80 & 0.12 & 10.0 & & \\
\hline Offset disk, $18 \mathrm{ft}$. & 10200 & 2000 & 200 & 60 & 6.00 & 18.00 & 0.80 & 0.10 & 10.0 & & \\
\hline Offset disk $21 \mathrm{ft}$. & 16900 & 2000 & 200 & 60 & 6.00 & 21.00 & 0.80 & 0.082 & 10.0 & & \\
\hline Fertilizer \& lime spreader, $4 \mathrm{t}, 40^{\circ}$ & 8000 & 1200 & 120 & 80 & 7.00 & 40.00 & 0.70 & 0.04 & 10.0 & & \\
\hline Grain drill, $25^{\prime}$ & 24900 & 1500 & 150 & 75 & 5.00 & 25.00 & 0.70 & 0.09 & 10.0 & & \\
\hline No-till drill (fertilizer attach), $15 \mathrm{ft}$. & 20500 & 1500 & 150 & 75 & 5.00 & 15.00 & 0.60 & 0.18 & 10.0 & & \\
\hline 4-row planter & 45000 & 1500 & 150 & 75 & & & & 0.67 & 10.0 & & \\
\hline Boom sprayer, $50^{\prime}$ & 4700 & 1500 & 150 & 70 & 3.00 & 50.00 & 0.60 & 0.09 & 10.0 & & \\
\hline Row cultivator, 2-36" & 2100 & 600 & 60 & 75 & 6.00 & 6.00 & 0.80 & 0.29 & 10.0 & . & \\
\hline Mower, $7^{\prime}$, bushhog & 3500 & 2000 & 200 & 175 & 5.00 & 7.00 & 0.80 & 0.29 & 10.0 & & \\
\hline Mower-conditioner, 7 & 7700 & 2500 & 250 & 80 & 4.50 & 7.00 & 0.80 & 0.33 & 10.0 & & \\
\hline Mower-conditioner, $12^{\prime}$ & 11700 & 2500 & 250 & 80 & 4.50 & 12.00 & 0.80 & 0.19 & 10.0 & & \\
\hline Side-delivery rake, $9^{\prime}$ & 3300 & 2500 & 250 & 60 & 6.00 & 9.00 & 0.80 & 0.19 & 10.0 & & \\
\hline Round baler, pto, 6'diam, 4'wide & 15480 & 1500 & 150 & 90 & 5.00 & 4.00 & 0.67 & 0.62 & 10.0 & & \\
\hline Round baler, pto, $<5$ 'diam, 4'wide & 11300 & 1500 & 150 & 90 & 5.00 & 4.00 & 0.65 & 0.63 & 10.0 & & \\
\hline Bale carrier, forklift & 2700 & 1000 & 100 & 40 & & & & & 10.0 & & \\
\hline Claas Jaguar harvester & 300000 & 6400 & 800 & 40 & & & 0.70 & & 8.0 & 17.48 & 0.080 \\
\hline High dump forage wagon $\left(1100 \mathrm{ft}^{3}\right)$ & 17739 & 2000 & 400 & 60 & & & & & 5.0 & & \\
\hline Tractor, $40 \mathrm{hp}$ & 16900 & 10000 & 833 & 100 & & & & & 12.0 & 1.98 & 0.014 \\
\hline Tractor, $60 \mathrm{hp}$ & 21400 & 10000 & 833 & 100 & & & & & 12.0 & 2.96 & 0.018 \\
\hline Tractor, $80 \mathrm{hp}$ & 27500 & 10000 & 833 & 100 & & & & & 12.0 & 3.95 & 0.023 \\
\hline Tractor, $100 \mathrm{hp} \mathrm{(cab,} \mathrm{air)}$ & 40100 & 10000 & 833 & 100 & & & & & 12.0 & 4.94 & 0.027 \\
\hline Tractor, $120 \mathrm{hp}$ (cab, air) & 55200 & 10000 & 833 & 100 & & & & & 12.0 & 5.93 & 0.031 \\
\hline Tractor, $225 \mathrm{hp}$, (cab, air) & 80500 & 10000 & 833 & 100 & & & & & 12.0 & 11.11 & 0.053 \\
\hline Truck, 2 ton, (hoist) & 45000 & 5000 & 500 & 60 & & & & & 10.0 & 3.75 & 0.035 \\
\hline Tandem truck (hay) & 52200 & 5000 & 500 & & 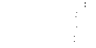 & & & & 10.0 & 4.70 & 0.035 \\
\hline Fork lift & 15300 & 5000 & 500 & & & & & & 10.0 & 1.98 & \\
\hline Pickup & 18400 & 5000 & 500 & 60 & & & & & 10.0 & 2.25 & 0.028 \\
\hline Truck tractor (wood) & 81500 & 10000 & 1000 & & & & & & 10.0 & & \\
\hline Chip van & 29000 & 6000 & 300 & & & & & & 20.0 & & \\
\hline
\end{tabular}


Table A3. Length of streams and buffer width by watershed in the Delmarva Peninsula in the Chesapeake Bay drainage

\begin{tabular}{|c|c|c|c|c|c|c|c|}
\hline \multirow{3}{*}{ Watershed } & & \multicolumn{5}{|c|}{ Length of stream with buffers of stated widths } & \multirow[b]{2}{*}{$\begin{array}{c}\text { Buffer } \\
\text { area } \\
\text { needed }\end{array}$} \\
\hline & $\begin{array}{l}\text { Stream } \\
\text { length }\end{array}$ & $\begin{array}{l}\text { Both sides } \\
100-300^{\prime}\end{array}$ & $\begin{array}{c}1 \text { side } \\
100-300^{\prime}\end{array}$ & $\begin{array}{l}\text { Both sides } \\
<100^{\circ}\end{array}$ & $\begin{array}{l}1 \text { side } \\
<100\end{array}$ & $\begin{array}{l}\text { Total } \\
\text { length } \\
<100^{\prime}\end{array}$ & \\
\hline & & \multicolumn{5}{|c|}{ miles } & acres \\
\hline \multicolumn{8}{|l|}{ Maryland } \\
\hline Pocomoke Sound & 150.8 & 30.2 & 37.8 & 113.0 & 7.6 & 233.6 & 2832 \\
\hline Lower Pokomoke River & 201.8 & 126.2 & 138.7 & 63.1 & 12.5 & 138.7 & 1681 \\
\hline Upper Pokomoke River & 125.8 & 72.8 & 75.5 & 50.3 & 2.7 & 103.3 & 1252 \\
\hline Dividing Creek & 57.4 & 49.9 & 51.3 & 6.1 & 1.4 & 13.6 & .165 \\
\hline Nassawango Creek & 60.2 & 44.4 & 46.2 & 14.0 & 1.8 & 29.8 & 361 \\
\hline Tangier Sound & 215.1 & 2.8 & 4.2 & 210.9 & 1.4 & 423.2 & 5130 \\
\hline Big Annemessex River & 115.7 & 17.4 & 22.3 & 93.4 & 4.9 & 191.7 & 2324 \\
\hline Manokin River & 204.4 & 50.0 & 59.1 & 145.3 & 9.1 & 299.7 & 3633 \\
\hline Lower Wicomico River & 206.9 & 47.9 & 55.7 & 151.2 & 7.8 & 310.2 & 3760 \\
\hline Monie Bay & 73.2 & 6.0 & 6.8 & 66.4 & 0.8 & 133.6 & 1619 \\
\hline Wicomico Creek & 44.4 & 14.3 & 16.7 & 27.7 & 2.4 & 57.8 & 701 \\
\hline Wicomico River Head & 62.6 & 32.2 & 36.1 & 26.5 & 3.9 & 56.9 & 690 \\
\hline Nanticoke River & 404.4 & 101.0 & 117.4 & 287.0 & 16.4 & 590.4 & 7156 \\
\hline Maryshope Creek & 291.7 & 136.3 & 154.8 & 136.9 & 18.5 & 292.3 & 3543 \\
\hline Fishing Bay & 499.1 & 28.6 & 37.1 & 462.0 & 8.5 & 932.5 & 11303 \\
\hline Transquaking River & 246.6 & 58.7 & 72.8 & 173.8 & 14.1 & 361.7 & 4384 \\
\hline Honga River & 212.2 & 8.8 & 11.3 & 200.9 & 2.5 & 404.3 & 4901 \\
\hline Little Choptank & 222.7 & 11.0 & 14.6 & 208.1 & 3.6 & 419.8 & 5088 \\
\hline Lower Choptank & 603.0 & 78.3 & 101.9 & 501.1 & 23.6 & 1025.8 & 12434 \\
\hline Upper Choptank & 539.7 & 245.8 & 278.7 & 261.0 & 32.9 & 554.9 & 6726 \\
\hline Tackahoe creek & 352.1 & 124.6 & 147.5 & 204.6 & 22.9 & 432.1 & 5238 \\
\hline Eastern Bay & 104.8 & 3.9 & 5.8 & 99.0 & 1.9 & 199.9 & 2423 \\
\hline Miles River & 133.6 & 18.3 & 23.7 & 109.9 & 5.4 & 225.2 & 2730 \\
\hline Wye River & 175.2 & 44.7 & 55.2 & 120.0 & 10.5 & 250.5 & 3036 \\
\hline $\begin{array}{l}\text { Total Maryland } \\
\text { Virginia }\end{array}$ & & & & & & 7681.5 & 93109 \\
\hline Pokomoke River/Pitts Creek & 44.9 & 19.9 & 23.1 & 21.8 & 3.2 & 46.8 & 567 \\
\hline $\begin{array}{l}\text { Chesapeake Bay/Holdens } \\
\text { Creek }\end{array}$ & 418.1 & 48.7 & 57.9 & 360.2 & 9.2 & 729.6 & 8844 \\
\hline Chesapeake Bay/Onancock & & & & & & & \\
\hline Creek & 135.3 & 6.3 & 8.4 & 126.9 & 2.1 & 255.9 & 3102 \\
\hline Pungoteague Creek & 39.2 & 8.1 & 9.3 & 29.9 & 1.2 & 61.0 & 739 \\
\hline Total Virginia & & & & & & 1093.3 & 13252 \\
\hline Total & & & & & & 8774.8 & 106361 \\
\hline
\end{tabular}




\section{APPENDIX B}

\section{FEDERAL, STATE AND NONGOVERNMENTAL PROGRAMS TO ENCOURAGE RIPARIAN BUFFER STRIPS}

There are a number of federal, state, and nongovernmental programs that help pay for best management practices, including establishment of riparian buffer strips. The Conservation Reserve Program (CRP), a federal program, pays $50 \%$ of establishment costs and an annual rental payment in return for removing land from agricultural production and establishing ground cover. Contracts covering CRP lands are for 10 to 15 years. No harvest is allowed during the contract period.

The Wetlands Reserve Program, a federal program, is designed to restore wetlands that have been drained or tilled. Payments from lands entered into this program range from a $75 \%$ cost share for a 10 -year contract to a $100 \%$ cost share and a lump sum payment based on agricultural value for a permanent program easement.

The Wildlife Habitat Incentive Program, a federal program, is designed to improve or increase wildlife habitat and other environmental benefits. Up to a $75 \%$ cost share is allowed for land in this program.

The Environmental Quality Incentives Program, a federal program, provides assistance to farmers to conserve soil, water, air, and other natural resources. Up to a $75 \%$ cost share is provided to establish riparian forest buffers and related practices under five- to 10-year contracts.

The Stewardship Incentive Program, a federal program, is designed to improve management of nonindustrial private forest land [0.4 to 405 ha ( 1 to 1000 acres)]. Eligible lands are forested or other rural lands suitable for conversion to program practices. Up to a $65 \%$ cost share for program practices is allowed, and the practices must be maintained for at least 10 years. Riparian and wetland improvement and protection are included.

The Forestry Incentives Program, a federal program, provides up to a $65 \%$ cost share for tree planting and site preparation.

The Maryland Agricultural Cost Share Program is designed to encourage farmers on farms with existing agriculturally related water quality problems to institute best management practices (BMPs) to control or reduce these problems. Up to $37.5 \%$ of eligible costs are reimbursed (in addition to federal reimbursement).

The Maryland Buffer Incentive Program provides a $\$ 741 / \mathrm{ha}(\$ 300 /$ acre) one time grant to land owners who plant and maintain forested buffers for a minimum of 10 years.

Maryland also has a Woodland Incentive Program and Virginia has a Woodland Buffer Filter Area program.

Only one federal program may be utilized on a parcel of land, but state programs may be piggybacked onto federal programs.

The Maryland Conservation Reserve Enhancement Program (referred to as the enhanced Conservation Reserve Program) combines the CRP with the Maryland Agricultural Water Quality Cost Share program, and Ducks Unlimited/Chesapeake Bay Foundation funds to provide $100 \%$ cost sharing for establishing riparian forest buffers and $95 \%$ for vegetative buffers on lands near streams. In addition the annual rental payment is increased by $70 \%$ for riparian forest buffers and 50\% for other practices. As with the CRP, contracts are for 10 to 15 years and no harvest is allowed during the contract. Costs are reimbursed up to $95 \%$ to $100 \%$ of a maximum amount based on the type of cover established:

Cool season grass seeding

Warm season grass seeding 
Softwood tree planting

Hardwood tree planting

Shrub planting

Weed control
$\$ 1050 /$ ha $(\$ 425 /$ acre $)$

$\$ 1420 /$ ha $(\$ 575 /$ acre $)$

$\$ 1976(\$ 800 /$ acre $)$

$\$ 124 /$ ha $(\$ 50 /$ acre $)$

A $\$ 12.35 /$ ha ( $\$ 5 /$ acre) maintenance fee is also paid for land in the enhanced CRP. If riparian forest buffers are established, Zone 1 must contain at least two native species plus less than $10 \%$ nonnative, noninvasive species. There is more flexibility in the choice of species in Zone 2. (Zones are defined on p. 4.) 
APPENDIX C

Chesapeake Bay Drainage 



\section{Chesapeake Bay Drainage}

There are two systems to load wood chips into chip vans: "hot" loading where the tractor stays attached to the van and "cold" loading where vans are delivered to a staging area by overthe-road tractors and older tractors deliver trailers to and remove trailers from the chipper. Both systems are used for harvesting short rotation woody crops (SRWC) by the forest products industry. Boise Cascade in eastern Washington uses a staging area (personal communication, Chuck Wierman, Boise Cascade, 9 June 1998) while Fort James Paper along the Columbia River in northwestern Oregon uses hot loading because of physical constraints (personal communication, Don Rice, Fort James Paper, 6 July 1998). The hot loading system is easier to model and I do not believe costs vary significantly between the two systems. I model the hot loading system.

The length of time required to fill a chip van depends on the size of the chipper and the size of the chip van. Johnson and Folk (1995) list three sizes of chippers (Table 1). Walsh and Becker (1996) use a $298 \mathrm{~kW}$ (400 hp) chipper with a $25 \mathrm{Mg} / \mathrm{hr}(27.5 \mathrm{ton} / \mathrm{hr})$ capacity in BIOCOST. Most states have an $36,300 \mathrm{~kg}(80,000$ pound) truck weight limit which allows for a $22,700 \mathrm{~kg}(50,000$ pound) [22.7 $\mathrm{Mg}$ (25 ton)] load. I assume a $14.6 \mathrm{~m}$ (48 ft) chip van with a 50,000 pound $[22.7 \mathrm{Mg}$ ( 25 ton)] load. The amount of time to fill the chip van as a function of chipper size is in Table 1. Rice says that typically it takes 30 to 35 minutes to fill a chip van, but can range from 20 minutes to 1 hour (personal communication from Don Rice, Fort James Paper, 6 July 1998). Stokes also states that a chip van can be filled in as little as 20 to 25 minutes (personal communication from Bryce Stokes, USFS, 3 June 1998). Note that these times are less than the times listed in Table 1 and the 0.73 hours ( 44 minutes) assumed by Walsh and Becker (1996) to load an $18.2 \mathrm{Mg}$ (20 ton) capacity chip van. Based on a chipper capacity of $25 \mathrm{Mg} / \mathrm{hr}$ ( $27.5 \mathrm{ton} / \mathrm{hr}$ ), a $22.7 \mathrm{Mg}$ ( $25 \mathrm{ton})$ load requires 55 minutes $(0.91 \mathrm{hr})$ to fill. I assume that it takes 55 minutes to fill a chip van. An alternative assumption is that it takes 35 minutes to fill a chip van, which implies a chipper capacity of $38.9 \mathrm{Mg} / \mathrm{hr}(42.9 \mathrm{ton} / \mathrm{hr})$.

Table C.1. Chipper costs and capacities from Johnson and Folk (1995)

\begin{tabular}{lcccccccc}
\hline Chipper size & & $\begin{array}{c}\text { Capital } \\
\text { cost }\end{array}$ & $\begin{array}{c}\text { Capital, } \\
\text { operating, } \\
\text { labor cost }\end{array}$ & & Capacity & \multicolumn{2}{c}{$\begin{array}{c}\text { Time to load a 22.7 } \\
\text { Mg (25 ton load }\end{array}$} \\
\hline & $\mathrm{hp}$ & $\mathrm{kW}$ & $1000 \$$ & $\$ / \mathrm{hr}$ & Tons/hr & $\mathrm{Mg} / \mathrm{hr}$ & Hours & Minutes \\
Small & 250 & 186 & 146.4 & 65 & 20.0 & 18.1 & 1.25 & 75 \\
Medium & 450 & 336 & 193.0 & 80 & 27.8 & 25.2 & 0.90 & 54 \\
Large & 600 & 448 & 244.6 & 96 & 39.4 & 35.7 & 0.63 & 38 \\
\hline
\end{tabular}

Johnson and Folk (1995) list a tractor-chip van as costing $\$ 110,500$. A $14.6 \mathrm{~m}$ (48 ft) double axle tandem chip van lists for $\$ 31,000$ which is approximately $\$ 29,000$ in 1995 dollars (personal communication from Don Nicely, Western Trailer, Boise, ID, 24 June 1998). This would mean that the tractor costs $\$ 81,500$, which is considerably more than the $\$ 52,000$ that Noon (1996) assumes for a tractor hauling switchgrass.

The most efficient way to unload wood chips at a conversion facility is to use a whole-truck dumper, where the tractor is not detached from the chip van. The next most efficient way is to 
use a trailer dumper, where the tractor is detached from the chip van. At Burlington Electric Company's McNeil Power Plant a trailer dumper is used. It takes a tractor-trailer 15 minutes from the time it goes in the plant gate, dumps its load, and exits the plant gate. The trailer dumper can handle up to 10 trucks $/ \mathrm{hr}$, but averages 3 trucks $/ \mathrm{hr}(68 \mathrm{Mg} / \mathrm{hr}(75 \mathrm{tons} / \mathrm{hr})]$ from 7 a.m. to 9 p.m., Monday through Saturday. A replacement trailer dumper is budgeted at $\$ 200,000$ (personal communication from John Irving, Burlington Electric Company, 8 June 1998). A whole-truck dumper would be even faster. I assume that a whole-truck dumper would only require a truck to use 10 minutes from the time it enters the plant gate to the time it exits the plant gate.

A 227 million L/year (60 million gallon/year) ethanol facility would require approximately 1.36 million $\mathrm{Mg} /$ year ( 1.5 million tons/year), or based on 300 delivery days/year for $14 \mathrm{hr} /$ day, $324 \mathrm{Mg} / \mathrm{hr}$ ( 357 tons $/ \mathrm{hr}$ ) must be delivered. This is approximately 14 trucks/hr. A $50 \mathrm{MW}_{\mathrm{e}}$ power plant uses $1 / 3$ the requirements of a 227 million L/year ( 60 million gallon/year) ethanol facility. Some large pulp mills process $9070 \mathrm{Mg}$ /day (10,000 tons/day). At some pulp mills trucks may require up to 2 hours to dump their loads because of congestion at the dumpers (personal communication, Bryce Stokes, USFS, 3 June 1998). For cost purposes, I assume adequate dumping capacity and that a truck requires 15 minutes from the time it enters the plant gate, dumps its load, and exits the plant gate.

Loading, transport, and unloading times for wood chips can vary considerably. Timelines for wood chip transportation by truck could be as follows:

$\begin{array}{lcccc}\text { Typical } & 55 \mathrm{~min} & & 15 \mathrm{~min} & \\ \begin{array}{l}(70 \mathrm{~min}+ \\ \text { travel time }+ \\ \text { slack time })\end{array} & \text { load } & \begin{array}{l}\text { travel to } \\ \text { conversion } \\ \text { facility }\end{array} & \begin{array}{c}\text { unload return to } \\ \text { chipping site }\end{array} & \text { time }\end{array}$

\begin{tabular}{|c|c|c|c|}
\hline & $25 \mathrm{~min}$ & $10 \mathrm{~min}$ & \\
\hline $\begin{array}{l}(35 \text { min }+ \\
\text { travel time }+ \\
\text { slack time })\end{array}$ & load & $\begin{array}{l}\text { travel to unload return to } \\
\text { conversion } \\
\text { facility }\end{array}$ & $\begin{array}{c}\text { slack } \\
\text { time }\end{array}$ \\
\hline
\end{tabular}

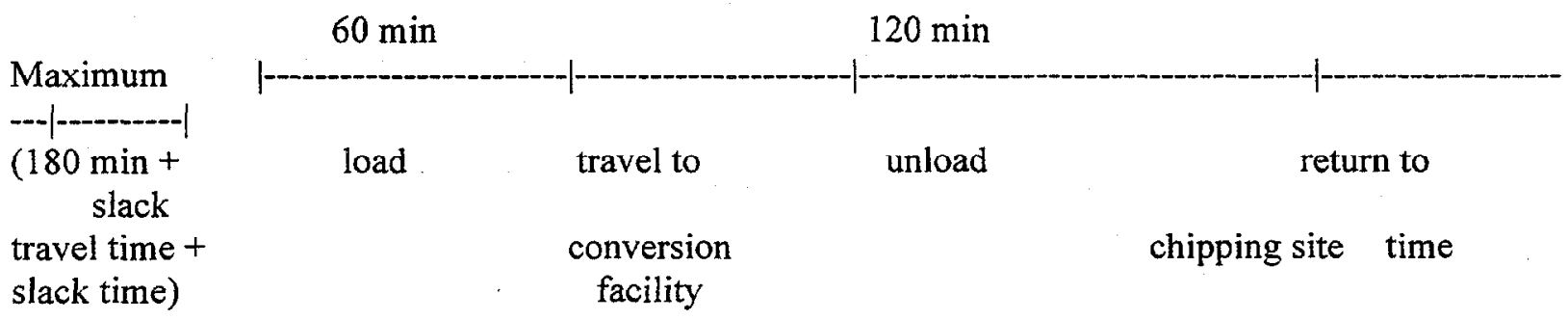

I currently model slack time (i.e., unproductive time) as 0.

The number of hours that a tractor and trailer operate in a year affects their costs. The Burlington Electric Company's McNeil Power Plant receives wood chips 14 hr/day, 6 days/wk (personal communication, John Irving, Burlington Electric Company, 8 June 1998). Fort James Paper along the Columbia River in northwestern Oregon harvests 8 to $12 \mathrm{hr} /$ day (personal communication from Don Rice, Fort James Paper, 6 July 1998). Trucks may be operating over $4000 \mathrm{hr} / \mathrm{yr}$.

In Noon (1996) hours of tractor operation are $2000 \mathrm{hr} / \mathrm{yr}$, which is the time the truck engine is running (over-the-road travel time plus unloading time). In Walsh and Becker (1996) hours of 
operation are assumed to be $500 \mathrm{hr} / \mathrm{yr}$, which appears to be over-the-road travel time, plus when the truck engine is on in at the chipper. Depending on how tractor time is allocated among loading, travel, unloading, and slack time; over-the-road travel time can vary between approximately 25 and $65 \%$ of total working time. Based on working $4000 \mathrm{hr} / \mathrm{yr}$, I assume that the tractor engine operates $2000 \mathrm{hr} / \mathrm{yr}$ as does Noon (1996). Fixed tractor costs (depreciation, interest, insurance, and fees) are allocated over these $2000 \mathrm{hr} / \mathrm{yr}$. Note that for switchgrass Noon (1996) assumed 1.5 trailers per tractor, a life of 10,000 hours for the tractor, and a trailer life of 5 years. This implies a trailer life of 6,667 hours. Because the trailer always stays attached to the tractor, it is used $2000 \mathrm{hr} / \mathrm{yr}$ and has a life of 3.33 years.

Tractor and trailer salvage value are discounted and calculated as:

$$
\frac{0.18 * \text { purchase price }}{(1+\text { real interest rate })^{\text {iffe }}}
$$

Noon does not use this formula but Walsh and Becker do.

Depreciation (called capital replacement in Walsh and Becker) per year is calculated as: (purchase price - discounted salvage value)

life

Interest (called non-land capital costs in Walsh and Becker) per year is calculated as: (purchase price + discounted salvage value) $*$ real interest rate

Note that this formula is different than what Noon (1996) uses for switchgrass, but the same as Walsh and Becker use. The real interest rate is assumed to be $6.5 \%$.

I assume tractor and trailer purchase costs of $\$ 81,500$ and $\$ 29,000$, respectively. For variable (tractor repair, lube, maintenance, and tire; trailer repair and tire) costs I use Noon's numbers.

Fuel and labor costs and tractor and trailer fees vary by region (Table 2). The Bureau of Labor Statistics (1998) lists average hourly earnings for tractor-trailer drivers of $\$ 14.07$ in 1995 and states that drivers in the west and northeast have higher and drivers in the southeast have lower than average earnings, but give no number data. I could find no regional wage data so I assume that wages in the northeast and Pacific northwest are $\$ 2 / \mathrm{hr}$ higher than average, in the midwest (lake states and corn belt) are average, and in the southeast (southeast, Appalachia, and southern plains) and northern plains are $\$ 2 / \mathrm{hr}$ less than average. I assume that benefits are $30 \%$ of the wage rate. Note that Walsh and Becker assume $\$ 12 / \mathrm{hr}$ for wages plus $20 \%$ for benefits, for a total labor cost of $\$ 14.40 / \mathrm{hr}$, which does not vary by region.

For fuel I assume that the trucks use diesel. Diesel prices excluding taxes are from Walsh and Becker (1996). In 1997 federal road use tax was $\$ 0.0644 / \mathrm{L}(\$ 0.244 /$ gal) and all states also charge diesel road use taxes. In addition some states charge sales tax and some states have additional per gallon and percent taxes for trucks. Data by state for taxes and fees are in the appendix, Table C7. In addition to the state fees there is a federal fee, $\$ 550$ in 1997 ( $\$ 518$ in 1995 dollars) for a $34,020 \mathrm{~kg}$ (75,000 pound) gross vehicle weight. All taxes and fees are adjusted to 1995 dollars assuming an average $3 \%$ inflation rate. 
Table C2. Regionalized data for fuel, labor, and fees (1995 dollars)

\begin{tabular}{clcccccc}
\hline $\begin{array}{r}\text { Region } \\
\text { number }\end{array}$ & \multicolumn{1}{c}{ Region } & $\$ / L$ & $\$ /$ gal & Tractor fee $(\$)$ & Trailer fee $(\$)$ & $\begin{array}{c}\text { Labor rate } \\
(\$ / \mathrm{hr})\end{array}$ & $\begin{array}{c}\text { Labor rate } \\
\text { including } \\
\text { benefits }(\$ / \mathrm{hr})\end{array}$ \\
\hline 1 & Northeast & 0.343 & 1.30 & 1652 & 75 & 16 & 20.80 \\
2 & Lake States & 0.336 & 1.27 & 2227 & 31 & 14 & 18.20 \\
3 & Corn Belt & 0.330 & 1.25 & 2246 & 16 & 14 & 18.20 \\
4 & Southeast & 0.306 & 1.16 & 1183 & 15 & 12 & 15.60 \\
5 & Appalachia & 0.312 & 1.18 & 1677 & 22 & 12 & 15.60 \\
6 & Delta States & 0.288 & 1.09 & 2148 & 18 & 12 & 15.60 \\
7 & Northern Plains & 0.309 & 1.17 & 1864 & 19 & 12 & 15.60 \\
8 & Southern Plains & 0.288 & 1.09 & 1449 & 31 & 12 & 15.60 \\
9 & Pacific Northwest & 0.333 & 1.26 & 1463 & 20 & 16 & 20.80 \\
\hline
\end{tabular}

Parameter values used in the model for costs that vary by distance and time are in Table 3. Variables used to determine FIXED_COST_PER_LOAD are unload time, which is costed at the VARIABLE_COST_PER_LOADHOUR and loading time which is charged at the labor rate. VARIABLE_COST_PER_LOADKM is the sum of tractor repair, lube, maintenance, and fuel costs; and trailer repair and tire costs. Fuel cost per $\mathrm{km}$ is based on the per gallon price of diesel divided by $7 \mathrm{~km}$ per gallon, as per Noon (1996). VARIABLE_COST_PER_LOADHOUR is the sum of tractor annual depreciation, interest, insurance, and fees; and trailer depreciation, interest, insurance, and fees; divided by hours of annual use. To get K_F, FIXED_COST_PER_LOAD is divided by dry $\mathrm{Mg}$ per load. And to get $\mathrm{K} \_\mathrm{D}$ and $\mathrm{K} \_\mathrm{T}$, VARIABBLE_COSTT_PER_LOĀDKM and VARIABLE_COST_PER LOADHOUR, respectively, are divided by dry $\mathrm{Mg}$ per load and multiplied by 2 (because K_D and K_T are defined for one-way distance and time).

Table C3. Tractor and trailer cost variables used by Noon (1996) and in this study

\begin{tabular}{|c|c|c|c|c|}
\hline Tractor variable name & $\begin{array}{l}\text { Noon } \\
\text { value }\end{array}$ & Trailer variable name & $\begin{array}{l}\text { Noon } \\
\text { value }\end{array}$ & $\begin{array}{c}\text { Value } \\
\text { this } \\
\text { study }\end{array}$ \\
\hline TRACTOR_REPAIR_COST_PER_KM & 0.07 & 0.07 TRAILER_REPAIR_COST_PER_KM & 0.02 & 0.02 \\
\hline TRACTOR_LUBE_COST_PER_KM & 0.01 & 0.01 TRAILER_LUBE_COST_PER_KM & 0 & 0 \\
\hline TRACTOR_MAINT_COST_PER_KM & 0.02 & 0.02 TRAILER_MAINT_COST_PER_KM & 0 & 0 \\
\hline TRACTOR_TIRE_COST_PER_KM & 0.02 & 0.02 TRAILER_TIRE_COST_PER_KM & 0.02 & 0.02 \\
\hline TRACTOR_FUEL_COST_PER_KM & 0.164 & $-^{2}$ & & \\
\hline COST_PER_GALLON_FUEL & 1.15 & $-^{2}$ & & \\
\hline \multirow[t]{2}{*}{ KM_PER_GALLON_FUEL } & 7 & 7 & & \\
\hline & & NUM_TRAILERS_PER_TRACTOR & 1.5 & 1 \\
\hline $\begin{array}{l}\text { TRACTOR_DEPRECIATION_PER_ } \\
\text { YEAR }\end{array}$ & 4000 & $\begin{array}{l}\text { TRAILER_DEPRECIATION_PER_ } \\
7369 \text { YEAR }\end{array}$ & 1200 & 7557 \\
\hline TRACTOR_INTEREST_PER_YEAR & 2040 & 2903 TRAILER_INTEREST_PER_YEAR & 276 & 1312 \\
\hline TRACTOR_INSURANCE_PER_YEAR & 7000 & 10971 TRAILER_INSURANCE_PER_YEAR & 250 & 1036 \\
\hline TRACTOR_FEES_PER_YEAR & 2400 & ${ }^{2}$ TRAILER_FEES_PER_YEAR & 70 & $a^{\mathrm{a}}$ \\
\hline TRACTOR_PURCHASE_COST & 52000 & 81500 TRAILER_PURCHASE_COST & 7000 & 29000 \\
\hline TRACTOR_SALVAGE_VALUE & 12000 & 7815 TRAILER_SALVAGE_VALUE & 1000 & 3810 \\
\hline TRACTOR LIFE YEARS & 10 & 10 TRAILER LIFE YEARS & 5 & 3.33 \\
\hline
\end{tabular}

${ }^{\mathrm{a}}$ Varies by region (see Table 2) 
One of the objectives of this study is to develop transportation costs from the point where Walsh and Becker (1996) end their calculations. Walsh and Becker (1996) and Noon (1996) use different assumptions and methodologies to determine transportation related costs. I try to reconcile some of these differences. For example, the assumed real interest rate is $6.5 \%$, and capital costs (depreciation and interest) are calculated the same. Walsh and Becker (1996) assume that tractors for chip vans operates $0.25 \mathrm{hr}$ /acre while loading chips. While this works out to be only 2 to 3 minutes per load, so costs are quite small, these costs must be subtracted from K_D and K_T. The major cost is the labor charge while the chip van is filled. This must be subtracted from the calculated K_F value. Adjusting K_F is straight forward.

First all transportation costs are calculated. Then the costs Walsh and Becker (1996) include in BIOCOST are subtracted from all transportation costs. Walsh's and Becker's data for chip vans are in Table 4. I take the Walsh and Becker data as is, except for labor costs which I price at my assumed labor rates. Note that the assumptions are not consistent between the Walsh and Becker data and how costs are calculated in Noon's spreadsheet (e.g. initial cost for a chip van and thus interest and depreciation, diesel price and use, taxes and insurance). (While this may be intellectually troubling, in terms of the effect on costs, it is quite small.) Repairs, fuel/lube, and tax/ins are grouped and modify K_D and cap/rep and non-land are grouped and modify K_T. Noon's numbers are on a per load basis. To get Walsh's and Becker's data on a per load basis, repairs, fuel/lube, and tax/ins are added together, multiplied by $0.25 \mathrm{hr} / \mathrm{acre}$ (loadkm column in Table 5), and divided by loads per acre; and cap/rep and non-land are added together, multiplied by $0.25 \mathrm{hr} / \mathrm{acre}$, and divided by loads per acre (loadhr column in Table 5).

loadkm column value in Table $5=$ (repairs + fuel $/$ lube + tax $/$ ins $) *(0.25 \mathrm{hr} / \mathrm{acre})$

loads/acre

loadhr column value in Table $5=(\mathrm{cap} / \mathrm{rep}$ and non-land $) *(0.25 \mathrm{hr} / \mathrm{acre})$

loads/acre

Note that loads/acre vary by region (Table 5) and that I have assumed $11.34 \mathrm{dry} \mathrm{Mg} /$ load in these calculations instead of the 9.1 dry $\mathrm{Mg} /$ load in Walsh and Becker. To get the adjusted $\mathrm{K} \_\mathrm{D}$ :

$\mathrm{K} \mathrm{D}_{\text {adjusted }}=\frac{\$ / \text { load-km(one-way)-\$/load(loadkm column value in Table } 5) * 2}{\text { distance(one way) }}$

$\mathrm{K} \_\mathrm{T}_{\text {adjusted }}=\$ /$ load-hr(one-way)-\$/load(loadhr column value in Table 5$)^{* 2}$ time(one way)

The loadhr and loadkm column values in Table 5 are multiplied by 2 because K_D and K_T are based on one-way distance and time, respectively. Unadjusted $K \_F, K \_D$, and $\bar{K}$ T values are found in cells B5, C5, and D5 (total transportation costs) and adjusted $\overline{\mathrm{K}} \mathrm{F}, \mathrm{K} \mathrm{D}$, and $\mathrm{K}, \mathrm{T}$ values are found in cells B5, C5, and D5 (total transportation costs minus Walsh and Becker costs for chip vans). 
Table C4. Walsh's and Becker's data for chip vans

\begin{tabular}{lcc}
\hline & Units & Chip van \\
Rate & hr/ha (hr/acre) & $0.62(0.25)$ \\
\hline Purchase price (\$) & $\$$ & 45000 \\
Salvage value (\$) & $\$$ & 8100 \\
Lifetime (yrs) & years & 10 \\
Annual use (hrs) & $\mathrm{hr}$ & 500 \\
Repair rates & lifetime, \% of list price & 60 \\
Fuel use & $\mathrm{L} / \mathrm{hr}(\mathrm{gal} / \mathrm{hr})$ & $14.2(3.75)$ \\
Oil use & $\mathrm{L} / \mathrm{hr}(\mathrm{gal} / \mathrm{hr})$ & $0.15(0.04)$ \\
Repairs & $\$ / \mathrm{hr}$ & 6.00 \\
Cap rep (depreciation) & $\$ / \mathrm{hr}$ & 7.38 \\
Non-land (interest) & $\$ / \mathrm{hr}$ & 3.45 \\
Fuel/lube & $\$ / \mathrm{hr}$ & 3.41 \\
Labor & $\$ / \mathrm{hr}$ & 14.40 \\
Tax/insurance & $\$ / \mathrm{hr}$ & 0.36 \\
\hline
\end{tabular}

Table C5. Data from Walsh and Becker used to adjust $K \mathrm{D}$ and $\mathrm{K} \mathrm{T}$

\begin{tabular}{lcccc}
\hline \multicolumn{1}{c}{ Region } & Yield (dt/acre) & Loads/acre & $\begin{array}{c}\text { Adjustment for } \\
\text { load-hr (per load) } \\
\text { loadhr }\end{array}$ & $\begin{array}{c}\text { Adjustment for } \\
\text { load-km(per load) } \\
\text { loadkm }\end{array}$ \\
\hline Northeast & 70 & 5.60 & 0.484 & 0.436 \\
Lake States & 70 & 5.60 & 0.484 & 0.436 \\
Corn Belt & 70 & 5.60 & 0.484 & 0.436 \\
Southeast & 63 & 5.04 & 0.537 & 0.485 \\
Appalachia & 70 & 5.60 & 0.484 & 0.436 \\
Delta States & 70 & 5.60 & 0.484 & 0.436 \\
Northern Plains & 70 & 5.60 & 0.484 & 0.436 \\
Southern Plains & 63 & 5.04 & 0.537 & 0.485 \\
Pacific Northwest & 63 & 5.04 & 0.537 & 0.485 \\
\hline
\end{tabular}

There is only one sheet in the spreadsheet. Each region is given a number (see Table 2 or cells $\mathrm{A} 63: \mathrm{B} 72$ ) and this region number is entered in cell B2. A sample of the spreadsheet output is in table 6. Note that $\mathrm{K} \_\mathrm{D}$ and $\mathrm{K} \_\mathrm{T}$ change little. I compared the total transportation costs based on large $(38.9 \mathrm{Mg} / \mathrm{hr})$ and medium $(25.0 \mathrm{Mg} / \mathrm{hr})$ chippers. In the southeast, costs were $\$ 8.45$ for the medium chipper and $\$ 8.00 /$ dry $\mathrm{Mg}$ for the large chipper. 
Table C6. Sample of spreadsheet output (based on distance of $40 \mathrm{~km}$ and time of $0.75 \mathrm{hr}$ )

\begin{tabular}{|c|c|c|c|c|}
\hline Units & $\frac{\text { Fixed cost }}{\text { K_F (\$/DRYTON })}$ & $\begin{array}{c}\frac{\text { Variable distance }}{K} \\
\text { K_D } \\
\text { (S/DRYTON-KM) }\end{array}$ & $\frac{\text { Variable time }}{\mathrm{K} T}$ & $\frac{\text { Total }}{(\$ / \mathrm{DRYTON})}$ \\
\hline \multirow[t]{2}{*}{ Noon methodology } & 1.948 & 0.0573 & 5.604 & 8.446 \\
\hline & K_F adjusted & K_D adjusted & K_T adjusted & $\begin{array}{l}\text { TOTAL } \\
\text { adjusted }\end{array}$ \\
\hline \multirow[t]{2}{*}{$\begin{array}{l}\text { Adjusted for Walsh } \\
\text { and Becker }\end{array}$} & 0.700 & 0.0552 & 5.477 & 7.018 \\
\hline & (\$/LOAD) & $\begin{array}{c}\text { (\$/LOAD-KM) } \\
\text { (1 way) }\end{array}$ & $\begin{array}{c}\text { (\$/LOAD-HOUR) } \\
\text { (1 way) }\end{array}$ & (\$/LOAD) \\
\hline $\begin{array}{l}\text { Total-Noon } \\
\text { methodology }\end{array}$ & 22.10 & 0.651 & 63.55 & 95.78 \\
\hline $\begin{array}{l}\text { Total adjusted for } \\
\text { Walsh and Becker }\end{array}$ & 7.94 & 0.626 & 62.11 & 79.58 \\
\hline
\end{tabular}

Table C7. State data for taxes and fees

\begin{tabular}{|c|c|c|c|c|c|c|c|c|c|c|}
\hline \multirow{3}{*}{ Region } & \multirow{3}{*}{$\begin{array}{c}\text { Price } \\
\text { exclud- } \\
\text { ing taxes }\end{array}$} & \multirow[t]{3}{*}{$\begin{array}{c}\text { Federal } \\
\text { tax-1997 }\end{array}$} & \multirow[t]{3}{*}{$\begin{array}{c}\text { State } \\
\text { tax-1996 }\end{array}$} & \multicolumn{2}{|c|}{ Sales tax-1996 } & \multicolumn{2}{|c|}{$\begin{array}{c}\begin{array}{c}\text { Additional } \\
\text { taxes- } 1996\end{array} \\
\text { Per gal }\end{array}$} & \multirow{2}{*}{$\begin{array}{l}\text { Total } \\
\text { diesel } \\
\text { price }\end{array}$} & \multicolumn{2}{|c|}{ Fees } \\
\hline & & & & $\begin{array}{l}\text { Exclud-ing } \\
\text { taxes }\end{array}$ & $\begin{array}{l}\text { Excluding } \\
\text { state taxes }\end{array}$ & & & & $\begin{array}{c}\text { Tractor- } \\
\text { trailer }\end{array}$ & $\begin{array}{c}\text { Trailer } \\
\text { only }\end{array}$ \\
\hline & & & & $\%$ & & \$/gal & $\%$ & $\begin{array}{c}1995 \$ / \\
\mathrm{gal}\end{array}$ & 199 & \\
\hline Northeast & 0.85 & 0.244 & 0.215 & & & & & 1.271 & 1117 & 71 \\
\hline Connecticut & 0.85 & 0.244 & 0.18 & & & & & 1.224 & 1555 & 35 \\
\hline Delaware & 0.85 & 0.244 & 0.22 & & & & & 1.259 & 880 & 368 \\
\hline Maine & 0.85 & 0.244 & 0.20 & & & & & 1.241 & 848 & 16 \\
\hline Maryland & 0.85 & 0.244 & 0.2425 & & & & & 1.279 & 1308 & 20 \\
\hline Massachusetts & 0.85 & 0.244 & 0.21 & & & & & 1.250 & 1450 & 250 \\
\hline New Hampshire & 0.85 & 0.244 & 0.187 & & & & & 1.230 & 712 & 0 \\
\hline New Jersey & 0.85 & 0.244 & 0.135 & & & & & 1.184 & 859 & 18 \\
\hline New York & 0.85 & 0.244 & 0.2174 & & 0.04 & 0.089 & & 1.384 & 989 & 23 \\
\hline Pennsylvania & 0.85 & 0.244 & 0.2235 & & & 0.06 & & 1.319 & 1152 & 27 \\
\hline Rhode Island & 0.85 & 0.244 & 0.29 & & & & & 1.321 & 875 & 5 \\
\hline Vermont & 0.85 & 0.244 & 0.26 & & & & & 1.294 & 1659 & 20 \\
\hline Lake States & 0.83 & 0.244 & 0.196 & & & & & 1.239 & 1659 & 30 \\
\hline Michigan & 0.83 & 0.244 & 0.15 & & 0.06 & & & 1.241 & 1316 & 39 \\
\hline Minnesota & 0.83 & 0.244 & 0.20 & & & & & 1.221 & 1760 & 0 \\
\hline Wisconsin & 0.83 & 0.244 & 0.237 & & & & & 1.254 & 1900 & 50 \\
\hline Corn Belt & 0.78 & 0.244 & 0.194 & & & & & 1.221 & 1676 & 15 \\
\hline Iowa & 0.78 & 0.244 & 0.225 & & & & & 1.193 & 1705 & 10 \\
\hline Illinois & 0.78 & 0.244 & 0.215 & 0.0625 & & 0.06 & & 1.290 & 2200 & 0 \\
\hline Indiana & 0.78 & 0.244 & 0.16 & 0.05 & & 0.11 & & 1.278 & 1382 & 31 \\
\hline Missouri & 0.78 & 0.244 & 0.15 & & & & & 1.127 & 1727 & 10 \\
\hline Ohio & 0.78 & 0.244 & 0.22 & & & 0.03 & & 1.217 & 1368 & 26 \\
\hline
\end{tabular}


Table C7 (continued)

\begin{tabular}{|c|c|c|c|c|c|c|c|c|c|c|}
\hline \multirow{3}{*}{ Region } & \multirow{3}{*}{$\begin{array}{c}\text { Price } \\
\text { exclud- } \\
\text { ing taxes }\end{array}$} & \multirow{3}{*}{$\begin{array}{c}\text { Federal } \\
\text { tax-1997 } \\
\text { \$/gal }\end{array}$} & \multirow{3}{*}{$\begin{array}{c}\text { State } \\
\text { tax-1996 }\end{array}$} & \multirow{2}{*}{\multicolumn{2}{|c|}{$\frac{\text { Sales tax-1996 }}{\begin{array}{l}\text { Exclud-ing } \\
\text { taxes }\end{array} \begin{array}{l}\text { Excluding } \\
\text { state taxes }\end{array}}$}} & \multicolumn{2}{|c|}{$\begin{array}{c}\begin{array}{c}\text { Additional } \\
\text { taxes-1996 } \\
\end{array} \\
\end{array}$} & \multirow{3}{*}{$\begin{array}{c}\begin{array}{c}\text { Total } \\
\text { diesel } \\
\text { price }\end{array} \\
\text { 1995\$/ } \\
\text { gal }\end{array}$} & \multicolumn{2}{|l|}{ Fees } \\
\hline & & & & & & Per gal & & & \multicolumn{2}{|c|}{$\begin{array}{cc}\text { Tractor- } & \text { Trailer } \\
\text { trailer } & \text { only }\end{array}$} \\
\hline & & & & $\%$ & $\%$ & \$/gal & $\%$ & & $1993 \$$ & \\
\hline Southeast & 0.78 & 0.244 & 0.142 & & & & & 1.133 & 675 & 14 \\
\hline Alabama & 0.78 & 0.244 & 0.19 & & & & & 1.163 & 802 & 21 \\
\hline Georgia & 0.78 & 0.244 & 0.075 & & 0.04 & & & 1.102 & 412 & 12 \\
\hline South Carolina & 0.78 & 0.244 & 0.16 & & & & & 1.136 & 810 & 10 \\
\hline Appalachia & 0.77 & 0.244 & 0.180 & & & & & 1.157 & 1140 & 21 \\
\hline Kentucky & 0.77 & 0.244 & 0.134 & & & 0.02 & 0.047 & 1.158 & 1280 & 20 \\
\hline North Carolina & 0.77 & 0.244 & 0.22 & & & & & 1.179 & 933 & 10 \\
\hline Tennessee & 0.77 & 0.244 & 0.17 & & & & & 1.135 & 1352 & 50 \\
\hline Virginia & 0.77 & 0.244 & 0.195 & & & & & 1.157 & 1003 & 24 \\
\hline West Virginia & 0.77 & 0.244 & 0.2535 & & & & & 1.209 & 1133 & 0 \\
\hline Delta States & 0.67 & 0.244 & 0.190 & & & & & 1.063 & 1584 & 17 \\
\hline Arkansas & 0.67 & 0.244 & 0.186 & 0.045 & & & & 1.079 & 1370 & 20 \\
\hline Louisiana & 0.67 & 0.244 & 0.20 & & & & & 1.061 & 490 & 10 \\
\hline Mississippi & 0.67 & 0.244 & 0.184 & & & & & 1.047 & 2892 & 20 \\
\hline Northern Plains & 0.74 & 0.244 & 0.209 & & & & & 1.139 & 1317 & 18 \\
\hline Kansas & 0.74 & 0.244 & 0.20 & & & & & 1.131 & 1764 & 37 \\
\hline Nebraska & 0.74 & 0.244 & 0.255 & & & & & 1.180 & 986 & 3 \\
\hline North Dakota & 0.74 & 0.244 & 0.20 & & & & & 1.131 & 1056 & 20 \\
\hline South Dakota & 0.74 & 0.244 & 0.18 & & & & & 1.114 & 1460 & 10 \\
\hline Southern Plains & 0.70 & 0.244 & 0.17 & & & & & 1.065 & 925 & 29 \\
\hline Oklahoma. & 0.70 & 0.244 & 0.14 & & & & & 1.039 & 994 & 43 \\
\hline Texas & 0.70 & 0.244 & 0.20 & & & & & 1.091 & 856 & 15 \\
\hline Pacific Northwest & 0.81 & 0.244 & 0.235 & & & & & 1.232 & 938 & 19 \\
\hline Oregon & 0.81 & 0.244 & 0.24 & & & & & 1.237 & 320 & 0 \\
\hline Washington & 0.81 & 0.244 & 0.23 & & & & & 1.228 & 1556 & 38 \\
\hline
\end{tabular}

Sources: FHWA (1993, 1998a,b), USDANASS (1996) 


\section{APPENDIX D}

\section{Derivation of price from net present value}

In calculating an average price for biomass over time, one sets:

discounted revenues $=$ discounts costs or

$$
\begin{gathered}
\sum_{j=1}^{n} \frac{P_{j} Y_{j}}{(1+i)^{j}}=\sum_{j=1}^{n} \frac{C_{j}}{(1+i)^{j}} \\
\mathrm{P}_{\mathrm{j}}=\mathrm{P} \text { for all } \mathrm{j} \\
P \sum_{j=1}^{n} \frac{Y_{j}}{(1+i)^{j}}=\sum_{j=1}^{n} \frac{C_{j}}{(1+i)^{j}} \\
P=\frac{\sum_{j=1}^{n}\left[\left(C_{j}\right) /(1+i)^{j}\right]}{\sum_{j=1}^{n}\left[Y_{j} /(1+i)^{j}\right]}
\end{gathered}
$$

where $\mathrm{P}=$ price

$P_{j}=$ price in year $j$

$Y_{j}=$ harvested yield in year $j$

$\mathrm{C}_{\mathrm{j}}=$ costs in year $\mathrm{j}$

$\mathrm{i}=$ discount rate. 

ORNL/TM-1999/146

\section{INTERNAL DISTRIBUTION}

1. M. Brown

2-26. L. S. Cooper

27. T. R. Curlee

28. J. H. Cushman

29. M. E. Downing

30. R. G. Gilliland

31. R. L. Graham

32. W. F. Harris

33. S. G. Hildebrand

34. G. K. Jacobs

35. L. A. Kszos

36. J. M. Loar
37. S. B. McLaughlin

38. R. D. Perlack

39. C. G. Rizy

40. A. C. Schaffhauser

41. R. B. Shelton

42. V.R. Tolbert

43. G. A. Tuskan

44. M. E. Walsh

45. L. L. Wright

46-48. ESD Library

49-50. ORNL Laboratory Records-OSTI

51. ORNL Laboratory Records-RC

\section{EXTERNAL DSTRIBUTION}

52. Bert R. Bock, Environmental Research \& Services, P.O. Box 1010, Tennessee Valley Authority, Muscle Shoals, AL 35662

53. Christina Caffo, CONEG Policy Research Center, Inc., 400 North Capitol Street, NW, Suite 382, Washington, DC 20001

54. Kevin Comer, Project Engineer, Antares Group Inc., 4351 Garden City Drive, Suite 301, Landover, MD 20785

55. Ray Costello, U.S. Dept. of Energy, Biomass Power Program, 1000 Independence Ave, SW EE-13, Washington DC 20585

56. Jerry Elwood, Acting Director, Environmental Sciences Division, SC-74, Department of Energy, 19901 Germantown Road, Germantown, MD 20874

57. John Ferrell, U.S. Dept. of Energy, Office of Fuels Development, 1000 Independence Avenue, EE-31/MS:6B-025 FORS, Washington, DC 20585

58. J. P. Giesy, College of Natural Science, Department of Zoology, Michigan State University, 203 Natural Science Building, East Lansing, MI 48824-1115

59. Rick Handley, Northeast Regional Biomass Energy Program, 400 North Capitol Street, NW, Suite 382, Washington, DC 20001

60. William Hohenstein, Environmental Protection Agency, Global Climate Change Division, 401 M Street, Room 3220, Washington DC 20460

61. Jacob Kaminsky, U.S. Dept. of Energy, Biomass Power Program, 1000 Independence Avenue, EE-13, Washington DC 20585

62. A. A. Lucier, National Council of the Paper Industry For Air and Stream Improvement, Inc., P.O. Box 13318, Research Triangle Park, NC 27709-3318

63. Charles Miller, Maryland Energy Administration, 45 Calvert Street, Annapolis MD 21401

64. G. M. Manthey, Acting ORNL Site Manager, Department of Energy, Oak Ridge National Laboratory, P.O. Box 2008, Oak Ridge, TN 37831-6269

65. Phil Polglaise, CSIRO Forestry and Forest Products, P.O. Box E4008, Kingston ACT 2604, Australia 
66. L. Robinson, Director, Environmental Sciences Institute, Florida A\&M University, Science Research Facility, 1520 S. Bronough Street, Tallahassee, FL 32307

67. Sarah Sprague, U.S. Dept. of Energy, Office of Fuels Development, EE-31, 1000 Independence Avenue, Washington, DC 20585

68. J. M. Tiedje, University Distinguished Professor and Director, Center for Microbial Ecology, Michigan State University, 540 Plant and Soil Sciences Building, East Lansing, MI 48824

69. Anthony Turhollow, 1511 E. 2050 North, North Logan, UT 84341-8804

70. David Wilson, RC\&D Coordinator, Maryland Eastern Shore RC\&D, 8133 Elliot Road, Suite 201, Easton, MD 21601. 